NBER WORKING PAPER SERIES

\title{
WHAT DETERMINES EFFECTIVENESS OF RENEWABLE ENERGY STANDARDS? GENERAL EQUILIBRIUM ANALYTICAL MODEL AND EMPIRICAL ANALYSIS
}

\author{
Don Fullerton \\ Chi L. Ta \\ Working Paper 29783 \\ http://www.nber.org/papers/w29783 \\ NATIONAL BUREAU OF ECONOMIC RESEARCH \\ 1050 Massachusetts Avenue \\ Cambridge, MA 02138 \\ February 2022
}

For helpful comments and suggestions, we wish to thank Tatyana Deryugina, Teevrat Garg, Alex Hollingsworth, Daniel Kaffine, Madhu Khanna, Erica Myers, Karen Palmer, and various seminar participants. The views expressed herein are those of the authors and do not necessarily reflect the views of the National Bureau of Economic Research.

At least one co-author has disclosed additional relationships of potential relevance for this research. Further information is available online at http://www.nber.org/papers/w29783.ack

NBER working papers are circulated for discussion and comment purposes. They have not been peer-reviewed or been subject to the review by the NBER Board of Directors that accompanies official NBER publications.

(C) 2022 by Don Fullerton and Chi L. Ta. All rights reserved. Short sections of text, not to exceed two paragraphs, may be quoted without explicit permission provided that full credit, including $(\odot$ notice, is given to the source. 
What Determines Effectiveness of Renewable Energy Standards? General Equilibrium Analytical Model and Empirical Analysis

Don Fullerton and Chi L. Ta

NBER Working Paper No. 29783

February 2022

JEL No. H23,Q28,Q42

\begin{abstract}
Our new analytical general equilibrium model is used to study effects of tightening state Renewable Portfolio Standards (RPS) on electricity price, $\mathrm{CO} 2$ emissions, fossil fuel electricity generation, and two kinds of renewable generation. We show how those outcomes depend on key state characteristics such as endowments of potential intermittent and non-intermittent ("dispatchable") renewable sources and the degree of intermittency. Our three extensions investigate key assumptions. We prove theorems and derive empirical hypotheses about what state characteristics makes RPS programs more effective. Using U.S. state-level data from 1990 to 2015, we find the data are consistent with these hypotheses.
\end{abstract}

\author{
Don Fullerton \\ Department of Finance \\ University of Illinois \\ 515 East Gregory Drive, BIF Box\#30 (MC520) \\ Champaign, IL 61820 \\ and NBER \\ dfullert@illinois.edu \\ Chi L. Ta \\ Department of Agricultural and Applied Economics \\ Hutcheson Hall 312 \\ 250 Drillfield Drive \\ BLACKSBURG, VA 24061 \\ United States \\ chita@vt.edu
}


Renewable Portfolio Standards (RPS) generally set a minimum percentage of electricity supplied by electric utilities to come from eligible renewable sources. These standards are among the most popular state-wide renewable energy programs in the U.S. and are mandatory in thirty states, Washington, D.C., and three territories. States' RPS goals are getting more ambitious in renewable share requirement and more aggressive in timing. ${ }^{1}$ Given worsening climate from greenhouse gas emissions, and the apparent political inability to enact a potentially first-best national carbon tax, both Presidents Obama and Biden have proposed second-best "clean energy standards" that are essentially an RPS at the national level.

When do such policies have major impacts on electricity price and generation as well as on environmental quality? This paper investigates the key factors that determine the effects of tightening RPS on electricity price, carbon dioxide $\left(\mathrm{CO}_{2}\right)$ emissions, fossil-fuel electricity, and renewable generation. Such information is useful to state policymakers who want to determine whether their own state has the characteristics that would make these standards successful.

Theoretical partial equilibrium (PE) models show ambiguous impacts of RPS on energy sources, prices, emissions, and energy consumption. ${ }^{2}$ Empirical studies find mixed evidence of the impacts on renewable generation but seem to agree on environmental benefits. ${ }^{3}$ Recently, Hollingsworth and Rudik (2018) develop a PE model to derive testable hypotheses for their empirical tests, primarily about the effects of a state's RPS on other states' emissions through Renewable Energy Credit (REC) programs. Greenstone and Nath (2020) use a PE framework to explain how the policy affects retail electric prices, and they employ a difference-in-differences event-study design to estimate the effects of RPS adoption on outcomes such as electricity price, generation, and emissions.

The PE approach does not account for economy-wide resource constraints, however, and it does not allow price adjustments in all markets. Since electricity is an input to production of other goods, an RPS in the electricity sector can significantly affect other output prices. Complex engineering and computational general equilibrium (GE) models can calculate the many impacts of an RPS, but these models often do not focus on the mechanisms. ${ }^{4}$

\footnotetext{
${ }^{1}$ https://www.ncsl.org/research/energy/renewable-portfolio-standards.aspx

${ }^{2}$ For examples, see Fischer and Newell (2008), Holland et al. (2009), and Fischer (2010).

${ }^{3}$ For examples, see Menz and Vachon (2006), Delmas and Montes-Sancho (2011), Yin and Powers (2010), Hitaj (2013), Upton and Snyder (2017), and Lyon (2016).

${ }^{4}$ For examples, see Logan et al. (2009), Rausch and Mowers (2014), and Ryan et al. (2016).
} 
To investigate mechanisms, Bento et al. (2018) employ an analytical GE model with numerical calibration to study the trade-off between impacts of the RPS on emission reductions vs. local booms (increases in rents from renewable energy endowments).

In this paper, we build a new analytical GE model to study how state-level characteristics are associated with the effects of an RPS on the in-state electricity price, emissions, fossil-fuel electricity, and renewable electricity. Like Bento et al. (2018), our analytical model can identify and investigate mechanisms, but we build upon that model and other literature in five ways. First, we explicitly model intermittent renewable sources separately from non-intermittent “dispatchable” renewable sources, and we show the importance of that distinction. Second, we include three extensions of the model, including an examination how a stricter RPS policy might interact with the state's energy efficiency mandate. Third, we show not just the effects of an RPS on emissions and renewables, but also what state characteristics determine the direction and size of each effect. Fourth, we use our GE model to prove theorems and derive hypotheses. Fifth, we provide empirical evidence that supports those hypotheses. The point of these contributions is for state analysts to learn about likely effects of a stricter RPS in their own state.

We now explain these five contributions further. First, our tractable GE model considers cost differences between fossil fuel and renewable technologies, and it distinguishes renewable sources based on intermittency. Traditional fossil fuel plants use well-developed technologies with a storable fuel supply. Renewable technologies, however, have not been fully developed. Some renewable sources are not intermittent and thus continuously dispatchable (e.g. hydro, biomass, and geothermal power). Other renewable sources like wind and solar are highly intermittent, as indicated in our data used below. Moreover, available evidence also shows that intermittency of sources adds significant costs to generation, integration, and distribution. ${ }^{5}$ We build this assumption into our GE model in order to show how this extra cost of intermittency also makes the RPS policy more effective for some states rather than others. States like Vermont

\footnotetext{
${ }^{5}$ Estimates of the "levelized cost of energy" (LCOE) from https://www.lazard.com/media/450337/lazard-levelizedcost-of-energy-version-110.pdf show that the low fossil-fuel generation costs are matched by wind after 2011 and by solar after 2013. We test our GE model using data from 1990-2015, a period during which intermittent renewable generation is still more costly. Moreover, those LCOE estimates do not include integration costs and thus understate the full costs of using intermittent resources. Borettii and Castelletto (2020) find that "estimation of performance and cost of wind energy facilities should include a parameter describing the variability, and an allowance for storage should be added to the cost.” Many empirical papers find that intermittency can significantly increase the cost of renewable electricity generation with integration (e.g., Denholm and Margolis 2007; Borenstein 2008; Joskow 2011; and Cullen 2013). Gowrisankaran et al (2016) find that "perfect dispatchability would lower the social cost of 20 percent solar by a substantial \$46 per MWh, in part by having the planner build six fewer generators.”
} 
and New Hampshire have higher endowments of biomass and hydropower than wind and solar power and therefore may not be affected by this cost differential. But other states like Arizona and New Mexico with great endowments of both wind and solar energy may have more trouble balancing electricity demand with intermittent power supply. Thus, our model is able to focus on how differences between states drive the relative cost-effectiveness of RPS policy.

Our tractable GE model is used to derive closed-form solutions for the effects of a state's RPS on prices, renewable generation, and emissions. We also use the basic model to decompose total effects on emissions and on renewable energy use into interpretable components. Thus, we highlight the key distinctions between renewables and how these distinctions matter. But this basic model is kept tractable by employing other simplifying assumptions: perfect competition, constant returns to scale production, and no other policies or other market distortions.

Second, therefore, we also consider model extensions to explore alternative specifications that allow for: (A) upward-sloping supply of fossil fuels, (B) imperfect competition in electricity generation, and (C) interaction of the RPS with an energy efficiency standard for appliances. Each of these extensions make the model somewhat more complicated, but none of them substantially alters the intuition regarding results from the basic model. Therefore, we return to the simpler basic model to undertake our other analyses.

Third, the closed-form solutions from the basic GE model show how each equilibrium effect of the RPS policy depends on all parameters in the model. Many of these parameters reflect characteristics of a state's economy, such as a state’s particular responsiveness, endowments, or share of electricity from each source. In other words, these closed-form solutions show how a state's characteristics affect the impact of an RPS on the electricity price, renewable generation, and all carbon emissions. Thus, we use the model to pinpoint exactly what key state characteristics determine the signs and magnitudes of these effects.

Fourth, we use the model to prove theorems and derive empirical hypotheses regarding those characteristics. Like prior papers, we find analytically that an RPS leads to unambiguous reductions in $\mathrm{CO}_{2}$ emissions but ambiguous effects on renewable energy generation. We provide intuition using the model below, but part of that intuition involves the extra cost of intermittent resources, and the negative income effect of those costs on demands for any kind of electricity. Using the analytical model, we prove three theorems. First, an RPS in a state with a larger endowment of intermittent sources will lead to larger reductions in emissions but smaller positive (or larger negative) effects on both kinds of renewable use. Second, in contrast, a state 
with larger endowments of dispatchable renewable sources will have a smaller negative effect on emissions and a larger positive (or smaller negative) effects on renewables. Third, a state with more intermittency of its intermittent sources will have larger negative effects on emissions and smaller positive (or larger negative) effects on renewables. These theorems lead to particular hypotheses about what we expect to find in the data.

Fifth, we use U.S. state-level panel data from 1990 to 2015 regarding key state characteristics, RPS stringency, and outcomes such as prices, emissions, and each type of generation. In particular, we examine whether empirical results are consistent with hypotheses from the analytical model. We exploit the differential timing of RPS adoption across states in two ways. First, we employ an event-study design to examine the changes in our key outcomes before and after RPS adoption. Second, we estimate coefficients on interactions of the policy requirement with key factors suggested by the analytical model.

A challenge to causal inference is the non-random implementation of state RPS policies. With panel data, we can employ standard fixed-effects that control for unobserved as well as observed time-invariant and state-specific confounders. Unobserved time-varying confounding factors can still result in omitted-variable bias, however, so our goal here is not to prove causation empirically. In other words, the controlled environment of our simple analytical model allows us to prove theorems that say what factors cause those outcomes, but we then use each theorem to state a hypothesis about what correlations we expect to find in the data. Using the empirical model, we show that the data are consistent with those hypotheses.

Below, Section 1 describes our basic model and interprets analytical results. Section 2 discusses extensions to the analytical model, and Section 3 derives the model's theorems and hypotheses. Section 4 describes the data and graphically examines changes in key outcomes before and after policy adoption. Section 5 presents the full empirical framework and results. Section 6 concludes. All appendices are included below, but later will be online only.

\section{Analytical General Equilibrium Model}

\subsection{Setup}

State Renewable Portfolio Standards generally set a minimum renewable electricity requirement as a fraction of total generation, but those requirements differ by size and timing. For example, Missouri requires $15 \%$ of generation to be from renewables by 2021, while New York requires $70 \%$ by 2030 , and Hawaii requires $100 \%$ by 2045 . Other RPS design features can 
also vary across states, such as geographical and technological eligibility and even the definition of renewable energy. Unlike most states, for example, Illinois disallows geothermal energy as an eligible renewable source. Colorado sets no geographic restriction on eligibility, while states like Hawaii and Iowa limit out-of-state generator eligibility. Many states allow the purchase of Renewable Energy Credits (RECs) from outside the state, the banking of excess RECs, and the use of those banked RECs to meet their state RPS requirements. Nearly half of states use a credit multiplier that gives "preferred" technologies more credit toward meeting the overall RPS target. New Mexico imposes no penalty for noncompliance. The penalty or alternative compliance payment is specified in other states such as Maryland, New Jersey, and Pennsylvania.

Our main objective is to design a GE model that is analytically tractable and yet can be used to study key determinants of the impacts of a state's RPS on emissions, renewable energy, prices, and welfare. Thus, our model compares two long-run equilibria, with no stranded capital nor transition path. In addition, we abstract from many details of RPS design features described above, as well as from government expenditures, other mandates, and taxes on inputs or outputs. Our GE model focuses on total electricity $(E)$, which is the sum of fossil-fuel electricity $(F)$ and renewable electricity $(R)$. The policy modeled here has two parts. The first part is a mandated minimum for renewables as a fraction of total electricity. Specifically, each state sets a policy scalar $\eta$ and requires that $R / E \geq \eta$. Assuming the standard is binding, we have:

$$
\frac{R}{E} \equiv \frac{R}{R+F}=\eta
$$

Second, RPS policies also often distinguish between intermittent renewables $R_{I}$, and dispatchable renewable power $R_{D}$. These two types of renewables are perfect substitutes in their use, but a state may encourage or require particular renewable technologies. Additional RPS requirements can appear in a state's definition of eligible renewables, targets for renewables, and “credit multipliers" that favor wind or solar for satisfying equation (1). Some states have "carveouts” that require a fraction of renewable power to come from wind or solar (for Illinois, 75\%). Our simple model cannot capture diverse ways that states encourage or require intermittent renewables, but we summarize this aspect of RPS rules by assuming a state can set a minimum for $R_{I}$ as a fraction of total renewables: $R_{I} / R \geq b$ (where $0<b<1$ ). This requirement is an integral part of each state's RPS, and it is used here to reflect heterogeneity across states. These credit multipliers and carve-outs also appear in our empirical work below. 
A plausible reason for these state differences is related to endowments. For example, Illinois differs from other states by not counting geothermal energy as an eligible renewable source, perhaps because it has no geothermal energy. Thus, we specify that the policy parameter $b$ is a function of the state's endowments of intermittent sources $Q_{I}$ and of dispatchable sources $Q_{D}$. We also suppose that a state's required $b$ depends on its renewable requirement $\eta$. To ensure this additional requirement is relevant, we assume it is costly and binding. Thus,

$$
R_{I}=b\left(Q_{I}, Q_{D}, \eta\right) R
$$

where $b$ varies across states in a way that is strictly increasing in the state's $Q_{I}$ and decreasing in its $Q_{D}$ (i.e., $\partial b / \partial Q_{I}>0$ and $\partial b / \partial Q_{D}<0$ ). It reflects the fact that these standards generally require more intermittent renewable electricity in states with more intermittent renewable sources. Similarly, they allow more dispatchable renewables in states with more of those sources. ${ }^{6}$ The state's $b$ is non-decreasing in its pre-existing policy scalar $\eta$, so $\partial b / \partial \eta \geq 0$. In fact, some states ratchet up the required fraction of electricity from wind and solar energy as they increase their required fraction of electricity from renewables. Derivations below employ a single exogenous policy change, $\eta$, so we use (2) to calculate the associated changes in $b$ and $R_{I}$.

For a GE model, we must also specify inputs for each output. We have no need to distinguish primary factors here, so we define a single factor $K$ as a composite of labor, capital, and land. We also aggregate final output into a single composite commodity, $X$. We consider a closed economy with perfect market conditions, so competitive firms take all input and output prices as given. They choose inputs to maximize profits subject to their constant returns to scale (CRTS) production technology. Firms in sector $X$ employ the primary factor in amount $K_{X}$ (at price $P_{K}$ ), and they use electricity $E$ (at price $P_{E}$ ). Fossil fuel and renewable electricity are perfect substitutes, so electricity has one price. Thus, production functions are:

$$
\begin{aligned}
& X=X\left(K_{X}, E\right), \\
& E=F+R .
\end{aligned}
$$

Good $X$ appears in utility below as an amount per household. Because of competition and CRTS, we can scale the entire economy so that all units are per household (including $X, E, F, R$, and $K_{X}$ ). State RPS policy directly affects the state's electricity sector in (4), and electricity is used as an

\footnotetext{
${ }^{6}$ Because $R_{I}$ must always be a fraction $b\left(Q_{I}, Q_{D}, \eta\right)$ of total $R$, we do not need another equation that specifies how $R_{D}$ must also depend on $Q_{I}$ and $Q_{D}$.
} 
input to other production in (3), so the policy can affect all sectors through GE channels. ${ }^{7}$

RPS policies apply only to the electric power sector, which in 2018 accounted for only $27 \%$ of U.S. greenhouse gas emissions. The remaining 73\% came from other sectors, including cement, oil refineries, and use of gasoline. ${ }^{8}$ Since our sector $X$ represents all final outputs other than electricity, we account for that breakdown by specifying that emissions are a by-product both from electricity and from production of $X$. We assume one unit of good $X$ emits a fixed $\zeta_{X}$ units of $\mathrm{CO}_{2}$. Within electricity, fossil fuels account for almost all greenhouse gas emissions, while production of renewable electricity is clean. Thus, we assume that emissions from the electricity sector come only from producing $F$, and that generation of one unit of $F$ emits $\zeta_{F}$ units of $\mathrm{CO}_{2}$. Thus, $\mathrm{CO}_{2}$ emissions per household are:

$$
C=\zeta_{F} F+\zeta_{X} X
$$

This specification has several advantages. First, the model can represent and track data on all emissions in all sectors. Second, increased RPS stringency may raise the price of electricity and induce consumer substitution toward other goods in sector $X$, so equation (5) can capture any increase in emissions from sector $X$. Thus, our GE model can show how policy in the electricity sector also affects emissions from the other sector.

For the production of fossil fuels, we abstract from limits on extraction and assume instead that electricity can be generated by a virtually limitless supply of coal. ${ }^{9}$ The only costs of production are for labor and capital to dig it up and burn it in generating plants. We choose units of measurement such that one unit of the primary factor $K_{F}$ produces one unit of $F$ :

$$
F=K_{F} \text {. }
$$

With only one input, $K$, we must also specify that renewable energy $R$ is produced using $K_{R}$. We cannot just say that each renewable is produced by CRTS using $K$, however, because then RPS mandates to substitute one for the other would have no cost to firms. Instead, we specify the remaining production functions as:

$$
\begin{aligned}
& R=R_{I}+R_{D}, \\
& R_{I}=A_{I}(\eta) K_{R I},
\end{aligned}
$$

\footnotetext{
${ }^{7}$ As shown below, this model is general enough to consider electricity used in consumption or production (or both).

${ }^{8}$ https://www.epa.gov/ghgemissions/inventory-us-greenhouse-gas-emissions-and-sinks

${ }^{9}$ We consider an upward-sloping supply of fossil fuels in one of our extensions below. However, it is unlikely that the supply of fossil fuels will become scarce in any near term, especially with current and future technological progresses in extracting new sources of fossil fuels with nearly limitless deposits (Covert et al., 2016).
} 


$$
R_{D}=A_{D} K_{R D}
$$

where $A_{I}(\eta)>0$ and $A_{D}>0$ are total factor productivities (TFP), and where $K_{R I}$ and $K_{R D}$ are primary factors used in production of $R_{I}$ and $R_{D}$. In production of $R_{I}$, we want to capture the idea that its marginal cost is increasing with the level of $R_{I}$. Wind and sunshine are not predictable, so more use of these intermittent sources requires more back-up generation, more batteries, and more risk of costly supply shortages. Also, transmission constraints mean that additional wind or solar power sources requires extending power lines further into remote locations. Thus, we want total factor productivity $A_{I}$ to fall as additional intermittent sources are required through policy (parameter $b$ ). Equation (2) specifies how $b$ is positively related to any exogenous change in $\eta$, so we can capture the desired effect by assuming that $A_{I}(\eta)$ is decreasing $\left(\partial A_{I} / \partial \eta<0\right)$.

Given these production functions, a value of $A_{I}>1$ or $A_{D}>1$ would imply that renewables are cheaper than fossil fuels (and all production would shift to the cheaper source). If $A_{I}=A_{D}=1$, then all sources are equally costly, and the RPS will not bind. Thus, we assume $0<A_{I} \leq A_{D}<1$, to analyze a costly and binding RPS and to capture the finding that $R_{I}$ is most costly. ${ }^{10}$

With all that detail on electricity production, we close the rest of the model in a simple and tractable fashion. Perfect competition and CRTS imply zero-profits, so the value of each sector's output produced and sold must equal the sum of spending on inputs to production:

$$
\begin{aligned}
& P_{X} X=P_{K} K_{X}+P_{E} E, \text { and } \\
& P_{E} E=P_{K} K_{E},
\end{aligned}
$$

where $K_{E}$ is the sum of primary factors used in producing all kinds of electricity:

$$
K_{E}=K_{F}+K_{R I}+K_{R D} \text {. }
$$

And, since all markets must clear in competitive equilibrium, the factor endowment must equal the sum of all factor uses:

$$
\bar{K}=K_{X}+K_{E} \text {. }
$$

To focus on equilibrium outcomes and economic efficiency, we assume $n$ identical households. Each is endowed with $\bar{K}$ of the primary factor, earning a price $P_{K}$. Each buys the composite good $X$, and each gets disutility from total emissions $n C$. Thus, utility is $U=$ $U(X ; n C)$, where $U$ is continuous, quasi-concave, and twice differentiable. It is increasing in $X$

\footnotetext{
${ }^{10}$ In an ad hoc manner, our model could also account for other RPS design features. For example, the allowance of REC trading and banking effectively reduces the cost of acquiring enough renewable electricity to satisfy the RPS. Those reduced costs can be captured through $A_{I}$ and $A_{D}$. Also, utilities can make an "alternative compliance payment”, allowing them to meet a less stringent standard (i.e., smaller $\eta$ ).
} 
and decreasing in aggregate emissions. ${ }^{11}$ With a large $n$, each household disregards its own contribution to total emissions and takes $n C$ as fixed. Each chooses $X$ to maximize utility subject to their budget constraint, $P_{X} X \leq I=P_{K} \bar{K}$, where $I$ is factor income.

\subsection{Linearization}

We use the initial policy scalar $\eta$ as the initial renewable share $(R / E)$, and we use the policy scalar $b$ as the initial ratio of intermittent renewables to total renewables $\left(R_{I} / R\right)$. Then, we study effects of a small exogenous increase in the RPS requirement ( $\hat{\eta} \equiv d \eta / \eta>0$ ) on inputs, outputs, and prices. To do so, we totally differentiate and linearize all equations (1)-(13), using the "hat" notation to denote any proportional change (e.g., $\hat{X} \equiv d X / X)$. First, we totally differentiate and rearrange the policy requirements in equations (1) and (2) to get:

$$
\begin{aligned}
& \hat{R}-\hat{E}=\hat{\eta}, \\
& \widehat{R_{I}}=b_{\eta} \hat{\eta}+\hat{R},
\end{aligned}
$$

where the scalar $b_{\eta} \equiv[\partial b / \partial \eta] \cdot\left[\eta / b\left(Q_{I}, Q_{D}, \eta\right)\right] \geq 0$ is the percentage increase in the fraction $b\left(Q_{I}, Q_{D}, \eta\right)$ attributable to a one percent increase in required renewable share $\eta$. Then, to show how changes to inputs determine changes in each output, we totally differentiate production functions in equations (3) to (9):

$$
\begin{aligned}
& \hat{X}=\theta_{K X} \widehat{K_{X}}+\theta_{E X} \hat{E}, \\
& \hat{E}=\eta \hat{R}+(1-\eta) \hat{F}, \\
& \hat{C}=\omega \hat{F}+(1-\omega) \hat{X}, \\
& \widehat{F}=\widehat{K_{F}}, \\
& \hat{R}=b \widehat{R_{I}}+(1-b) \widehat{R_{D}}, \\
& \widehat{R_{I}}=\alpha_{I \eta} \hat{\eta}+\widehat{K_{R I}}, \\
& \widehat{R_{D}}=\widehat{K_{R D}},
\end{aligned}
$$

where $\theta_{K X}$ and $\theta_{E X}$ denote factor shares in sector $X$ (and $\theta_{K X}+\theta_{E X}=1$ ), and $\omega$ represents the electricity sector's share of total $\mathrm{CO}_{2}$ emissions. The scalar $\alpha_{I \eta} \equiv\left[\partial A_{I} / \partial \eta\right] \cdot\left[\eta / A_{I}(\eta)\right]<0$ is the percentage reduction in $A_{I}(\eta)$ from a one percent increase in the required renewable share.

Similarly, we totally differentiate the zero-profit equation (10) and use the firm's first

\footnotetext{
11 This model can consider electricity used in consumption or production (or both). Substitute $X=X\left(K_{X}, E\right)$ into utility to get $U=U\left[X\left(K_{X}, E\right) ; n C\right]$, and then interpret $X(\because ;)$ as a sub-utility function that depends on two goods, where $K_{X}$ is a consumption good produced using only $K$, and $E$ is household use of energy. Thus, $E$ in our model can be interpreted to represent household use, firm use, or simply the aggregate use of electricity.
} 
order conditions to show how the price of output $X$ must change to reflect input cost changes. Then differentiate (11) to ensure that $P_{E} E$ still equals $P_{K} K_{E}$ (with no pure profits):

$$
\begin{aligned}
& \widehat{P_{X}}=\theta_{K X} \widehat{P_{K}}+\theta_{E X} \widehat{P_{E}} \\
& \widehat{P_{E}}+\widehat{E}=\widehat{P_{K}}+\widehat{K_{E}} .
\end{aligned}
$$

The elasticity of substitution between inputs in production of $X$ is $\sigma_{X}>0$, defined as the percentage change in the input quantity ratio in response to a percent change in the input price ratio. For small changes, the definition of $\sigma_{X}$ implies:

$$
\widehat{K_{X}}-\widehat{E}=\sigma_{X}\left(\widehat{P_{E}}-\widehat{P_{K}}\right) .
$$

Next, totally differentiate resource constraint equations (12) - (13) and manipulate:

$$
\begin{aligned}
& \widehat{K_{E}}=\delta_{F} \widehat{K_{F}}+\delta_{R I} \widehat{K_{R I}}+\delta_{R D} \widehat{K_{R D}}, \\
& 0=\gamma_{X} \widehat{K_{X}}+\gamma_{E} \widehat{K_{E}} .
\end{aligned}
$$

where $\delta_{F} \equiv K_{F} / K_{E}$ and $\delta_{R} \equiv K_{R} / K_{E}$ are the initial fractions of the total primary factor used in the production of electricity that are employed in fossil-fuel electricity and in renewable electricity $\left(\delta_{F}+\delta_{R I}+\delta_{R D}=1\right)$. We use $\gamma_{X} \equiv K_{X} / \bar{K}$ and $\gamma_{E} \equiv K_{E} / \bar{K}$ to denote the fraction of the total primary factor used in each sector $\left(\gamma_{X}+\gamma_{E}=1\right)$. Finally, we choose the primary factor $K$ as numeraire, so $\widehat{P_{K}}=0$.

\subsection{Solutions}

We use the fourteen linear equations (14)-(27) to solve for fourteen unknown changes $\left(\widehat{X}, \widehat{P_{X}}, \widehat{K_{X}}, \widehat{K_{R I}}, \widehat{K_{R D}}, \widehat{K_{F}}, \widehat{K_{E}}, \widehat{P_{X}}, \widehat{P_{E}}, \widehat{R_{I}}, \widehat{R}, \widehat{R_{D}}, \widehat{F}\right.$ and $\left.\hat{E}\right)$. These closed-form solutions show each price and quantity change as a function of the state's parameters and exogenous RPS policy shock, $\hat{\eta}>0$. Appendix A shows step-by-step derivations and closed-form solutions for all outcomes. Here, we show how to decompose the effects of the policy shock for ten key outcomes and to interpret the components. We start with the change in electricity price:

$$
\widehat{P_{E}}=\left(\delta_{R I}\left(1-A_{I}\right)+\delta_{R D}\left(1-A_{D}\right)\right) \hat{\eta}-\delta_{R I} \alpha_{I \eta} \hat{\eta}+\left(1-\frac{A_{I}}{A_{D}}\right) \delta_{R I} b_{\eta} \hat{\eta}
$$

The first long term on the right is positive and is interpreted here as the differential production cost for electricity from renewables. Recall that $A_{I}<1$ is the TFP for generation using intermittent sources (in $R_{I}=A_{I} K_{R I}$ ) relative to using cheaper fossil fuels (in $F=K_{F}$ ). Thus, $\left(1-A_{I}\right.$ ) is the extra cost of using intermittent sources, and it is weighted by the share $\delta_{R I}=K_{R I} / K_{E}$. Similarly, $\left(1-A_{D}\right)$ is the extra cost of using dispatchable sources and is weighted by $\delta_{R D}=K_{R D} / K_{E}$. The 
second term also has an unambiguously positive effect on price, because $\alpha_{I \eta}<0$ is the elasticity of $A_{I}$ with respect to $\eta$. It reflects the cost of integrating more intermittent sources into the grid. The increase in a binding RPS requirement leads to higher costs of intermittency, storage limitations, and transmission constraints. Thus, the second term is the integration cost from increasing the required renewable share. In the third term, $b_{\eta} \geq 0$ and $0<A_{I} \leq A_{D}<1$, so this term is non-negative. It represents the extra cost of requiring intermittent sources as the preferred way to meet the overall RPS requirement. This extra intermittent requirement cost is zero if production costs are equalized across renewables $\left(A_{I}=A_{D}\right)$, or if firms are allowed to keep the pre-existing ratio of intermittent renewables to total renewable electricity $\left(b_{\eta}=0\right)$.

Equation (28) shows a closed-form solution for $\widehat{P_{E}}$ as a function only of parameters and the exogenous policy shock $\hat{\eta}$. Other outcomes are similarly closed-form, but we show them next as functions of $\hat{\eta}$ and $\widehat{P_{E}}$ (where substitution from equation (28) provides the closed form):

$$
\begin{aligned}
& \widehat{P_{X}}=\theta_{E X} \widehat{P_{E}} \\
& \hat{X}=-\gamma_{E} \widehat{P_{E}} \\
& \widehat{K_{X}}=-\gamma_{E} \widehat{P_{E}}+\gamma_{E} \sigma_{X} \widehat{P_{E}} \\
& \hat{E}=-\gamma_{E} \widehat{P_{E}}-\gamma_{X} \sigma_{X} \widehat{P_{E}} \\
& \hat{F}=-\gamma_{E} \widehat{P_{E}}-\gamma_{X} \sigma_{X} \widehat{P_{E}}-\frac{\eta}{1-\eta} \hat{\eta} \\
& \hat{C}=-\gamma_{E} \widehat{P_{E}}-\omega \gamma_{X} \sigma_{X} \widehat{P_{E}}-\frac{\omega \eta}{1-\eta} \hat{\eta} \\
& \hat{R}=-\gamma_{E} \widehat{P_{E}}-\gamma_{X} \sigma_{X} \widehat{P_{E}}+\widehat{\eta} \\
& \widehat{R_{I}}=-\gamma_{E} \widehat{P_{E}}-\gamma_{X} \sigma_{X} \widehat{P_{E}}+\widehat{\eta}+b_{\eta} \widehat{\eta} \\
& \widehat{R_{D}}=-\gamma_{E} \widehat{P_{E}}-\gamma_{X} \sigma_{X} \widehat{P_{E}}+\widehat{\eta}-\frac{b b_{\eta}}{(1-b)} \widehat{\eta}
\end{aligned}
$$

The output $X$ is produced using only electricity and primary factors. Since the latter is numeraire, equation (29) shows that the price of $X$ must rise with the price of electricity times its input share, $\theta_{E X}$. Then, of course, this increase in $P_{X}$ means that households reduce consumption of $X$ in equation (30). But this effect is not the usual "price effect". The composite good $X$ is the only purchased good in utility, so its price is essentially a price index over all goods. Its higher price reduces real income, so the reduction of $X$ in equation (30) is really an income effect.

In fact, as we now show, this income effect on $X$ is identical to the overall change in real 
income (the welfare gain or loss, ignoring changes in emissions). We differentiate the utility function and use the consumer's first order condition to show that the dollar value of the change in utility is $d U / \mu=P_{X} d X$, where $\mu$ is the marginal utility of income. We divide both sides by total income $(I)$ to express it in relative terms and solve for the change in welfare as:

$$
\frac{d U}{\mu I}=\frac{P_{X} X}{I} \hat{X}=\hat{X}<0
$$

This relative change in welfare is exactly the earlier-derived income effect on $X$.

Then, equations (31) and (32) show overall effects on inputs of primary factors $K_{X}$ and electricity $E$. The first term in both equations is $-\gamma_{E} \widehat{P_{E}}$, matching the income effect just derived. The second term in (31) is $\gamma_{E} \sigma_{X} \widehat{P_{E}}$, a substitution effect on the input of $K_{X}$ that depends on the elasticity of substitution in production, $\sigma_{X}$, and the change in the other input price, $\widehat{P_{E}}$. The price of electricity rises relative to the numeraire price $P_{K}$, so firms in $X$ substitute away from use of electricity and toward the primary factor. Similarly, the substitution effect on input of $E$ in (32) is $-\gamma_{X} \sigma_{X} \widehat{P_{E}}<0$. Both substitution and income effects reduce electricity use, so $\widehat{E}<0$. The sign of the effect of the policy on the primary factor use $K_{X}$ is ambiguous, as it depends on whether the substitution effect or income effect dominates.

Finally, equations (33)-(37) show effects of the policy change on each type of electricity and on $\mathrm{CO}_{2}$ emissions. The first term in all five equations, $-\gamma_{E} \widehat{P_{E}}$, is an income effect as shown above. The second term in $\widehat{F}, \widehat{R}, \widehat{R}_{I}$, and $\widehat{R_{D}}$ matches the substitution effect in $\widehat{E}$, because the raised price of electricity reduces demand for electricity regardless of source. The third term in (33) is $-\frac{\eta}{1-\eta} \hat{\eta}<0$, capturing a direct policy effect that reduces fossil fuel electricity as intended. The third term in (35)-(37) is another direct policy effect, $\hat{\eta}>0$, which increases renewable electricity (either intermittent or dispatchable renewable electricity). The last terms in (36) and (37) show the effect on the mix of renewables if the state ratchets up the intermittent renewable requirement $b$ along with the overall standard $\eta$. If the elasticity $\left(b_{\eta} \geq 0\right)$ is not zero, then the last term in $\widehat{R_{I}}$ is positive and the one in $\widehat{R_{D}}$ is negative.

With the assumption that production of renewable electricity is costlier than fossil-fuel electricity ( $A_{I}<1$ and $\left.A_{D}<1\right)$, we find that fossil fuels in (33) are reduced by the income effect, the substitution effect, and the direct policy effect. Emissions in (34) therefore unambiguously fall. However, the overall effect of the RPS on renewable electricity is ambiguous: $R$ is reduced both by the income effect and by substitution in production of $X$, while it rises with the direct 
policy effect. The sign of $\hat{R}$ depends on which effects dominate. ${ }^{12}$ We later show the exact conditions under which total renewable energy rises or falls.

\section{Model extensions}

The advantage of our simple analytical GE model is that our solutions show exactly which parameters determine the effects of the RPS policy and how they do so. As a simplified description of reality, however, our model surely imposes some restrictive assumptions. This section extends our model to relax three key assumptions. We allow for: (A) upward-sloping supply of fossil fuels, (B) imperfect competition in electricity generation, and (C) interaction of the RPS with a renewable energy efficiency standard.

\section{A. Upward-sloping supply of fossil fuels}

Since the RPS policy discourages fossil-fuel power, it shifts down the demand for fossil fuels. If extraction has a rising marginal cost, this shift can reduce the equilibrium price of fossil fuels and encourage more use of them. In other words, an RPS can reduce the price of electricity (Fischer, 2010). The size of this effect depends on the slope of that marginal cost (supply curve). Our basic model employs a flat supply, so it cannot capture any effect on the relative price of $F$. To account for an upward-sloping supply of fossil fuels, we make a slight change to equation (5) and model production of fossil fuel electricity as $F=A_{F}(\eta) K_{F}$, where $A_{F}$ is an increasing function of $\eta$. Then a higher renewable requirement $(\eta)$ raises the productivity of using fossil fuels (moves down the marginal cost curve).

In the base model, $A_{F}=1$ and $0<A_{I} \leq A_{D}<1$, so here we assume $0<A_{I} \leq A_{D}<A_{F}$. Thus, renewable electricity is costlier than fossil fuel electricity, so the RPS policy is costly and binding. With linearization, equation (19) becomes $\hat{F}=\alpha_{F \eta} \hat{\eta}+\widehat{K_{F}}$, where the scalar $\alpha_{F \eta} \equiv$ $\left[\partial A_{F} / \partial \eta\right] \cdot\left[\eta / A_{F}(\eta)\right]>0$ is the percentage increase in $A_{F}(\eta)$ from a one percent increase in the required renewable share. Following steps similar to those in Appendix A, we solve for the change in the price of electricity:

$$
\widehat{P_{E}}=\left[\delta_{R I}\left(1-\frac{A_{I}}{A_{F}}\right)+\delta_{R D}\left(1-\frac{A_{D}}{A_{F}}\right)\right] \hat{\eta}-\delta_{F} \alpha_{F \eta} \hat{\eta}-\delta_{R I} \alpha_{I \eta} \hat{\eta}+\left(1-\frac{A_{I}}{A_{D}}\right) \delta_{R I} b_{\eta} \hat{\eta}
$$

\footnotetext{
12 This ambiguous effect on renewables was also found in prior papers such as Fischer (2010), Bento et al (2018), and Hollingsworth and Rudik (2018). They capture the positive direct policy effect on renewables and the negative substitution effect when electricity gets more expensive. Here, we also capture economy-wide income effects. Real incomes are reduced by the requirement that scarce resources be used in the production of more costly renewables.
} 
Compared to $\widehat{P_{E}}$ in equation (28) above, the first term is still the differential production cost of using renewables (except $A_{I}$ is now divided by $A_{F}$ ). The last two terms are unchanged (the integration cost and the intermittent requirement cost). All those terms are still positive. This extension adds the second term $-\delta_{F} \alpha_{F \eta} \hat{\eta}<0$, which includes a new elasticity reflecting the fall in cost from the slope of supply. However, the supply curve for fossil fuels like coal is fairly flat, so $\alpha_{F \eta}$ is likely small. If so, then this added term means a smaller increase in the electricity price and a smaller reduction in emissions. Also, the reduction in the marginal cost of extraction reduces the economic cost of the policy. Other results are qualitatively similar.

\section{B. Imperfect competition in the electricity market}

Many states regulate the retail electricity price to consumers, so these markets are neither perfectly competitive nor monopolistic. Here, we account for imperfect competition in the electricity market, modeled simply as a firm's ability to charge a price higher than marginal cost. We define $\tau>0$ as a fixed percentage markup of price over marginal cost. Essentially, a higher value of $\tau$ implies a higher degree of market power. This assumption does not reflect a "monopoly", which could react to changes in cost by changing the markup. It does not reflect a particular oligopoly behavior either. It is just a simple way to suppose that firms may not be perfectly competitive and so may charge a price higher than marginal cost.

Households receive the firm's profits. We can think of $\tau$ as a sales tax, with its revenue distributed back to consumers in a lump-sum fashion. Thus, the purchase price of electricity is $P_{E}(1+\tau)$, and equation (10) becomes $P_{X} X=P_{K} K_{X}+(1+\tau) P_{E} E$. Linearizing the new set of equations yields the exact same solutions as in our basic model, since markup is a fixed fraction of the producer price (i.e., $\hat{\tau}=0$ ). Intuitively, the markup raises the initial $P_{E}$, but all results are unchanged, so a tighter RPS has the same incremental effect as in our basic model. ${ }^{13}$

\section{Interaction with an energy efficiency standard}

\footnotetext{
${ }^{13}$ Even with the markup as a fixed fraction $\tau$, we can study the effect of the policy shock across various levels of initial market power. But we ignore the possibility that the policy shock affects market power and changes the markup. Consideration of $\hat{\tau} \neq 0$ would add more terms to our solutions but would not alter our key results and interpretations. Alternatively, we also modelled the markup as a fixed dollar amount, which also leaves unchanged incremental effect of a tighter RPS on $P_{E}$. However, the same increase in $P_{E}$ implies a smaller increase in purchase price of electricity relative to the numeraire $P_{K}$. As a result, firms in $X$ substitute less away from electricity. This smaller shift of inputs away from $E_{X}$ toward $K_{X}$ does not substantially change results of our basic model, namely that the change in emissions is unambiguously negative and that the change in renewables can have either sign.
} 
Third, we consider whether interactions with an energy efficiency standard (EES) might enhance or undermine the impacts of the RPS. ${ }^{14}$ With its required minimum renewable electricity per unit of total electricity, the RPS can be satisfied either by increased use of renewables or by reduced use of fossil-fuels (or some of each). At the same time, however, an EES requires reduced use of any electricity for certain appliances (regardless of generating source). The two policies might interact to reduce the use of fossil-fuel electricity with no significant change in renewable electricity production. In other words, an energy efficiency standard might weaken the impact of an RPS on renewable deployment.

To model the EES, we suppose that a component of the composite good $X$ is a flow of services from durables that use electricity, and we add a new policy scalar $\epsilon$ to its production function: $X=X\left(K_{X}, \epsilon E\right)$. A value of $\epsilon>1$ means that a given electricity $E$ yields more $X$, but this extra energy efficiency also has a cost. This extra cost must be expressed in terms of primary input, and is a function of $\epsilon$, so this cost is given by $K_{S}=K_{S}(\epsilon)$. This extra factor use is added to the market-clearing condition: $\bar{K}=K_{X}+K_{E}+K_{S}$. We follow steps in Appendix A to derive all equilibrium changes caused by an increase in the RPS requirement $(\hat{\eta}>0)$ given the pre-existing $\operatorname{EES}(\hat{\epsilon}=0)$. We find that solutions are unchanged for $\widehat{P_{E}}$ and electricity $\left(\widehat{E}=\left(\gamma_{E}+\gamma_{X} \sigma_{X}\right) \widehat{P_{E}}\right)$. But we find new solutions for components of electricity:

$$
\begin{aligned}
& \hat{R}=-\frac{1}{1-\gamma_{S}}\left(\gamma_{E}+\gamma_{X} \sigma_{X}\right) \widehat{P_{E}}+\hat{\eta} \\
& \hat{F}=-\frac{1}{\left(1-\gamma_{S}\right)}\left(\gamma_{E}+\gamma_{X} \sigma_{X}\right) \widehat{P_{E}}-\frac{\eta}{(1-\eta)} \hat{\eta} \\
& \hat{C}=-\frac{1}{\left(1-\gamma_{S}\right)}\left(\gamma_{E}+\omega \gamma_{X} \sigma_{X}\right) \widehat{P_{E}}-\frac{\omega \eta}{(1-\eta)} \hat{\eta}
\end{aligned}
$$

These new expressions are the same as before except for the first ratio, where the new parameter $\gamma_{S}$ is the fraction of primary factors used for the required energy efficiency $\left(K_{S} / \bar{K}\right)$. The EES draws resources away from $R$ and $F$ toward energy efficiency technologies. Since $1 /\left(1-\gamma_{S}\right)$ is greater than one, its inclusion here scales up the negative first term in all three equations (the impact on all electricity). But it does not change our main findings, namely, the unambiguous reductions in fossil fuels and emissions but ambiguous impact on renewable generation.

\footnotetext{
${ }^{14}$ In a PE framework, Fell et al. (2017) find that combining an intensity standard and energy efficiency credit can yield first-best outcomes with an inelastic demand for energy services but not in the case of elastic demand.
} 


\section{Theorems and Hypotheses}

Using our basic analytical results, we derive theorems about what state characteristics drive the impacts of tightening a state's RPS. First, previous sections show that a tighter RPS unambiguously reduces fossil-fuel electricity and emissions but has an ambiguous effect on renewable energy. These analytical results explain mixed evidence in prior empirical literature about the impacts of the RPS on renewable energy. Using equations (28), (36), and (37), we show here the exact conditions under which tightening the RPS can reduce either intermittent or dispatchable renewable electricity:

$$
\begin{aligned}
& \widehat{R_{I}}<0 \text { whenever }\left(\gamma_{E}+\gamma_{X} \sigma_{X}\right)\left(\delta_{R I}\left(1-A_{I}-\alpha_{I \eta}\right)+\delta_{R D}\left(1-A_{D}\right)\right)>1+b_{\eta}, \\
& \widehat{R_{D}}<0 \text { whenever }\left(\gamma_{E}+\gamma_{X} \sigma_{X}\right)\left(\delta_{R I}\left(1-A_{I}-\alpha_{I \eta}\right)+\delta_{R D}\left(1-A_{D}\right)\right)>1-b_{\eta} \frac{b}{1-b} .
\end{aligned}
$$

These conditions point to key parameters that determine the sign of the change in each type of renewable. Both conditions have the same left-hand side, which is positive: both $A_{I}$ and $A_{D}$ are less than one, while $\alpha_{I \eta}$ is negative, so $\left(1-A_{I}-\alpha_{I \eta}\right)>0$ and $\left(1-A_{D}\right)>0$. The right-hand sides of the two conditions have opposite signs in front of the elasticity parameter $b_{\eta}>0$ (which captures the increase in intermittent renewable requirement $b$ that accompanies an increase in the overall standard $\eta$. Then, these two conditions show that:

1. A larger $\sigma_{X}$ makes $\widehat{R_{I}}$ and $\widehat{R_{D}}$ more likely negative. Firms can substitute away from electricity more easily, so they reduce demand for all sources of electricity.

2. A larger initial share of resources in renewables $\left(\delta_{R I} \equiv K_{R I} / K_{E}\right.$ or $\left.\delta_{R D} \equiv K_{R D} / K_{E}\right)$ means that pre-existing costs of the RPS are already high, so the added cost of a more stringent RPS has further income effects that reduce both kinds of renewable generation.

3. A larger absolute value of the integration cost elasticity $\left(\alpha_{I \eta}<0\right)$ also means that the policy shock is costly, with negative income effects on both renewables.

A larger size of any of these parameters makes both the income and substitution effects larger, which discourages renewables and tends to offset the intended direct policy effect.

Next, we wish to examine key factors that affect these RPS impacts, so we totally differentiate five of our solutions: $\widehat{P_{E}}$ in equation (28), $\widehat{F}$ in (33), $\hat{C}$ in (34), $\widehat{R_{I}}$ in (36), and $\widehat{R_{D}}$ in (37). Differentiation with respect to key parameters yields theorems about the effect of the RPS on those outcomes. Proofs are in Appendix B. We also use these theorems to generate hypotheses about empirical results (as summarized in Table 1). Then we use U.S. state-by-year panel data to examine whether the data are consistent with those hypotheses. Many parameters appear in these three equations, but we focus on the ones for which we can find data, or at least proxies that can represent differences in these key factors across states. 
First, we have state data on available renewable sources like sun and wind, so we can investigate how the impact of an RPS on the five outcomes correlate with these local characteristics. Our first Theorem shows how the intermittent endowment $Q_{I}$ affects the impacts of an RPS on electricity price, fossil fuel generation, carbon emissions and renewable generation.

Theorem T1: The derivative of $\widehat{P_{E}}$ with respect to $Q_{I}$ is positive, so a larger intermittent resource endowment $\left(Q_{I}\right)$ means larger positive impact of tightening RPS on electricity price. Derivatives of $\hat{F}$ and $\hat{C}$ with respect to $Q_{I}$ are negative, so a larger intermittent endowment means larger negative impacts of tightening an RPS on fossil-fuel electricity and emissions. Derivatives of $\widehat{R_{I}}$ and $\widehat{R_{D}}$ with respect to $Q_{I}$ are also negative, so a larger intermittent endowment means smaller positive (or larger negative) impact of an RPS on both renewables. [Proof: see Appendix B.]

States with more intermittent renewable endowments most often require or use more of those renewables to meet their RPS requirement. ${ }^{15}$ As explained above, however, the marginal cost of integrating more intermittent renewables into the electric grid increases with the share of generation already from intermittent sources (due to storage limitations and transmission costs). Thus, an RPS that requires more intermittent generation (an increase in $b$ ) has a higher cost and thus increases electricity price. The larger negative income effect leads to a larger reduction in fossil-fuel electricity production and a smaller increase (or larger decrease) in both kinds of renewable electricity production. So, this theorem yields empirical predictions:

Hypothesis H1: States with greater endowments of intermittent renewable sources will be found to have a larger positive correlation between their RPS renewable requirements and electricity price, larger negative correlations with fossil-fuel electricity and emissions, and smaller positive (or larger negative) correlations with both kinds of renewable energy.

Our next theorem shows that having more dispatchable renewable endowments $Q_{D}$ implies the opposite impacts on all five outcomes from increased RPS requirement.

Theorem T2: The derivative of $\widehat{P_{E}}$ with respect to $Q_{D}$ is negative, so a larger dispatchable resource endowment $\left(Q_{D}\right)$ means smaller positive impact of tightening RPS on electricity price. Derivatives of $\hat{F}$ and $\hat{C}$ with respect to $Q_{D}$ are positive, so a larger endowment $Q_{D}$ means smaller negative impacts of tightening an RPS on fossil-fuel electricity and emissions. Derivatives of $\widehat{R_{I}}$ and $\widehat{R_{D}}$ with respect to $Q_{D}$ are also positive, so a larger endowment $Q_{D}$ means larger positive (or smaller negative) impacts of an RPS on both renewables. [Proof: see Appendix B.]

\footnotetext{
${ }^{15}$ We rank states according to their ratio of intermittent renewable potential $\left(Q_{I}\right)$ to dispatchable renewable potential $\left(Q_{D}\right)$. These potential renewable data come from a study by the National Renewable Energy Laboratory (Lopez et al., 2012). Next, we rank states according to their actual ratio of $R_{I}$ generation to $R_{D}$ generation in two recent years (2010 and 2015). Electricity generation data are from the U.S. Energy Information Administration. The rank order correlation coefficients are +0.43 and +0.65 . This calculation supports the claim in the text.
} 
States with more endowments of dispatchable renewable resources typically allow more use of dispatchable renewable electricity to meet their RPS. This type of electricity is generally cheaper than intermittent renewables electricity, so tightening the RPS has a lower cost and thus increases the electricity price by less. ${ }^{16}$ The smaller negative income effect results in a smaller reduction in fossil-fuel electricity and a larger increase (or smaller decrease) in renewables.

Hypothesis H2: States with greater dispatchable renewable energy endowments will be found to have a smaller positive correlation between the RPS requirement and electricity price, smaller negative correlations with fossil-fuel electricity and $\mathrm{CO}_{2}$ emissions, and larger positive (or smaller negative) correlations with both kinds of renewable energy.

Next, we find effects of $\alpha_{I \eta} \equiv\left[\partial A_{I} / \partial \eta\right] \cdot\left[\eta / A_{I}\right]<0$, the percentage reduction in $A_{I}(\eta)$ attributable to a one percent increase in the required renewable share $\eta$.

Theorem T3: The derivative of $\widehat{P_{E}}$ with respect to $\alpha_{I \eta}$ is negative, so a larger absolute size cost elasticity (a more negative $\alpha_{I \eta}$ ) means a larger positive impact of tightening RPS on electricity price. Derivatives of $\hat{F}$ and $\hat{C}$ with respect to $\alpha_{I \eta}$ are positive, so a larger cost elasticity means larger negative impacts of tightening an RPS on fossil-fuel electricity and emissions. Derivatives of $\widehat{R_{I}}$ and $\widehat{R_{D}}$ with respect to $\alpha_{I \eta}$ are also positive, so a larger size cost elasticity means smaller positive (or larger negative) impacts of an RPS on both renewables. [Proof: Appendix B.]

A greater absolute value of $\alpha_{I \eta}$ means that renewable share requirement $\eta$ has a larger impact on the cost of generating and integrating renewable energy. It then has a larger positive impact on the price of electricity, which increases the negative income and substitution effects on the quantity of electricity production (from any source). Those effects reduce both emissions and renewable electricity generation. We have no direct data on the cost elasticity $\alpha_{I \eta}$ across states. However, prior studies show that costs of integrating intermittent renewable energy into existing power systems increase with the level of penetration and are largely attributable to the intermittent nature of renewable sources (Mills and Wiser, 2012; Hirth et al., 2015). So, an appropriate proxy for the cost sensitivity $\left(\alpha_{I \eta}\right)$ is a measure of the variability of wind or sunshine. Thus, theorem T3 gives rise to the following empirical prediction:

Hypothesis H3: States with greater intermittency of renewable resources will be found to have a larger positive correlation between their RPS requirements and electricity price, larger negative correlations with fossil fuel electricity and emissions, and smaller positive (or larger negative) correlations with both kinds of renewable energy.

${ }^{16}$ Recall that each state sets $b$ as the minimum ratio $R_{I} / R$, where $b=b\left(Q_{I}, Q_{D}, \eta\right)$. This $b$ varies across states such that that $\partial b / \partial Q_{I}>0$ and $\partial b / \partial Q_{D}<0$. Thus, more $Q_{D}$ means less cost from a less restrictive requirement $R_{I} / R \geq b$. 


\section{Data}

\section{Dependent Variables}

For each year from 1990 to 2015, we obtain each state's annual electricity price, per capita $\mathrm{CO}_{2}$ emissions (in metric tons), and per capita electricity generation for each source (in MWh) from the U.S. Energy Information Administration (EIA). ${ }^{17}$ We define dispatchable renewable electricity to come from hydro, biomass, and geothermal power. Intermittent renewable electricity is generated from wind and solar energy. ${ }^{18}$ Table 2 provides summary statistics for all variables.

\section{Variables for Renewable Portfolio Standards}

We construct an indicator for adoption of RPS, $a$-rps $i$, by assigning one to a state $i$ that has adopted an RPS in year $t$ and zero otherwise. Data on RPS are from the Database of State Incentives for Renewable and Efficiency (DSIRE). ${ }^{19}$ The mean of the RPS adoption dummy in Table 2 is 0.269 , which indicates that slightly more than one-quarter of the pooled observations have adopted the RPS policy, but this simple average over all states in all years does not reveal that the RPS has expanded to sixty percent of states toward the end of the period.

State RPS policies differ in several dimensions. One important heterogeneity across state RPS policies is in their stated targets and timeframes. For example, Missouri sets a renewable target of $15 \%$ by 2021, and New York targets 70\% by 2030. Many state laws set annual "interim" requirements to help achieve the final target. We ignore planning for distant future requirements, but we construct a variable $r$-rps $i t$ to represent the "effective interim requirement" in state $i$ at year $t$. For states that do not set interim requirements every year but only every several years, we interpolate for intervening years by calculating the average increase per year in the requirement from one interim requirement to the next. Our $r$-rpsit variable is each year's effective RPS requirement (whether stated by law or interpolated). ${ }^{20}$

\footnotetext{
${ }^{17}$ We collect data for 46 contiguous states. We exclude Texas and Iowa because those two states do not set minimum percentage renewable requirements but instead minimum renewable capacity requirements. We exclude Hawaii and Alaska due to unavailable or missing data on key variables.

${ }^{18}$ Our empirical application focuses on electricity generation rather than capacity, because our key variables in the analytical model are electricity generation for each source. More importantly, the RPS specifically requires the minimum renewable generation as a fraction of total electricity generation.

19 http://www.dsireusa.org/resources/data-and-tools/

${ }^{20}$ Also, the types of utilities subject to RPS vary by state. We calculate each state’s RPS “coverage” (from 0 to 1 ) from its share of electricity sold by utilities that are covered by the RPS (using 2015 electricity sales data in Form
} 
Other features of state RPS policies favor certain renewable technologies. For example, “credit multipliers” may give wind or solar power extra credits toward overall RPS requirements, and "carve-outs" specify for them a minimum percentage of the overall renewable requirement. These features are incorporated into our GE model by equation (2), which requires a minimum ratio of intermittent renewables to total renewables. In our empirical analysis, we also allow for the impact of RPS to depend on these state characteristics. We construct a dummy variable Multiplier $_{\text {it }}$ that is equal to one if the state has an enacted RPS and uses credit multipliers, and a dummy Carveout ${ }_{\text {it }}$ equal to one if it has a carve-out requirement.

Two other features of RPS systems include: (1) allowing renewable energy certificate (REC) trading and (2) alternative compliance payments (ACP). Some RPS states allow the purchase of RECs from other states to meet their own RPS requirement, if those RECs are cheaper than renewable options within the state itself. In addition, some states specify the ACP amount that an applicable electricity provider must pay to cover each unit of required renewable electricity for which they are unable either to generate themselves or to buy RECs instead. The ACP can be seen as the upper bound of the compliance cost, but this provision might also help reinforce compliance with the standard. Both the REC trading and the ACP can affect the compliance cost for applicable entities, so we create two dummy variables: Trading $\mathrm{it}_{\mathrm{it}}$ is equal to one if the state RPS allows REC trading (and zero otherwise), while $A C P_{\text {it, }}$ takes the value one if the state RPS uses an ACP (and zero otherwise).

\section{Key Factors}

Our analytical model emphasizes different costs of producing renewable electricity as key sources of differences in the impacts of RPS across states. Those costs can depend on a state's endowments and intermittency of renewable resources. We construct intermittent renewable potential $i-r e p_{i}$ as the log of potential capacity from wind and solar energy, and dispatchable renewable potential $d-r e p_{i}$ as the log of potential capacity from hydro, biomass, and geothermal energy. Those potential capacity data come from a study by the National Renewable

EIA-861M). Our $r$-rps it variable is the calculated coverage times the RPS requirement. Still, this variable does not reflect how stringency is affected by state enforcement penalties, or by a state's high actual renewable share (which can make the legal requirement non-binding). A key assumption of our analytical model is that the policy is binding. Given that many RPS design features such as RECs vary significantly across states, we cannot construct a valid single measure of "stringency" that is consistent across states. Instead, we examine whether data are consistent with predictions from our analytical model. Insignificant estimated coefficients could indicate the policy is not binding. 
Energy Laboratory (Lopez et al., 2012) and do not change over time. We use $i$-rep $p_{i}$ and $d$-rep r $_{i}$ as proxies for the state's endowments of renewables.

To measure wind energy's intermittency, we make use of a power curve that relates power generation to wind speed. The power curve specifies: (i) the cut-in speed, which allows wind turbine blades to rotate and generate power; (ii) the rated speed, which enables a wind turbine to produce its maximum power level, and (iii) the cut-out speed, above which wind turbines are shut down to prevent damage. We follow Ren et al. (2017) to measure wind intermittency as the frequency that a typical wind turbine switches between (1) power-generation status when wind speed is between the cut-in speed and the cut-out speed, and (2) shutdown status when wind speed is below the cut-in speed or above the cut-out speed. ${ }^{21}$ We use hourly wind speed data provided by the National Oceanic and Atmospheric Administration (NOAA) for all available weather stations in 2005. In miles per hour, we use 8 for the cut-in speed, 31 for the rated speed, and 55 for the cut-out speed. ${ }^{22}$ With one observation per station per hour all year, we follow Ren et al. (2017) by measuring wind intermittency as the actual number of on-or-off switches across all stations in the state during the year as a fraction of total observations across all stations in the state in that year. Table 2 shows that the mean of wind intermittency is 0.2037 , so switches occur in $20 \%$ of the observed hours. Our variable $w$-inter $r_{i}$ is the log of that wind intermittency measure for the state. ${ }^{23}$

\section{Other Explanatory Variables}

First, we include the logs of cooling and heating degree days ( $c d d_{i t}$ and $\left.h d d_{i t}\right)$ from NOAA, and the League of Conservation Voters scores for the U.S. House and Senate (hlcvit and $\left.s l c v_{i t}\right)$. They rate each state's Members of the U.S. Congress by average voting records on key environmental, public health, and energy issues. States with Members that vote in favor of more environmental bills score higher. We also include citizen ideology (c-ideo $\left.{ }_{i t}\right)$, measured as the mean position of a state's active electorate on a liberal-conservative continuum, and state government ideology ( $g$-ideo $i t)$, measured on the same continuum as the power-weighted mean

\footnotetext{
${ }^{21}$ Ren et al. (2017) provide a good summary of existing measurements of wind intermittency and their limitations. They also propose a new wind-speed based measurement that we choose to use here, partly because high frequency wind speed data are publicly available for all states in our sample.

22 https://www.energy.gov/eere/articles/how-do-wind-turbines-survive-severe-storms

${ }^{23}$ We cannot find a suitable measure of solar intermittency. We are reluctant to invent and use a measure that has no evidence of validity or usefulness, but our measure of wind intermittency has good supporting evidence.
} 
position of the elected public officials. ${ }^{24} \mathrm{We}$ include logged natural gas price (ngp $\left.\mathrm{p}_{i t}\right)$ and the electricity import ratio $\left(e-i m p_{i t}\right)$, constructed as the state's electricity sales minus generation divided by sales (all from the U.S. EIA). Appendix C checks robustness to variable inclusion. ${ }^{25}$ State electricity market regulation and other environmental policies can also affect state $\mathrm{CO}_{2}$ emissions and renewable energy. We include an indicator variable $e$-res $s_{i t}$ that equals one if the state has a deregulated or restructured electricity market (and zero otherwise). ${ }^{26}$ States often deregulate the electricity market to bring in more competition, to reduce electricity prices, and to promote alternative energy. Deregulation data are available from the EIA

As well, we include a dummy for corporate tax incentives (tax $x_{i t}$ ) that equals one if state $i$ has corporate tax incentives for renewables in year $t$ (and zero otherwise). We construct a binary variable $s p f_{i t}$ that equals one if state $i$ maintains a state public fund for renewable benefits in year $t$. We include an indicator for energy efficiency standards (ees $\left.s_{i t}\right)$. Those standards often require utilities to reduce some specified percentage of projected energy sales through energy efficiency measures such as customers' end-use efficiency programs run by utilities or third-party program operators. Data on renewable policies are from DSIRE.

\section{Preliminary Empirical Analysis of RPS Adoption}

Before looking at the RPS ratio itself, we first employ our data to look at how the initial RPS adoption affects outcome variables (electricity price, emissions, fossil-fuel electricity, and renewable electricity). Here, we use a difference-in-differences event-study empirical approach to examine outcomes graphically before and after policy adoption and to assess the pre-treatment trends between states with and without an RPS. ${ }^{27}$ We pool information for all states that adopted

\footnotetext{
${ }^{24}$ Richard Fording generously shared these data (see https://rcfording.wordpress.com/state-ideology-data/).

${ }^{25}$ Given widespread RPS and interconnected electricity systems among states, the policy can affect both electricity import ratios and natural gas prices. Thus, these variables are potentially bad controls, and including them in the regression could bias estimates of the effects of RPS. However, both electricity import ratio and natural gas price can be correlated with the implementation of RPS. Thus, omitting those variables might also lead to omitted variable biases. To be parsimonious, we do not include these two variables in our main specification in Tables 3 and 4 . But robustness checks include them as controls, as shown in Tables C1-C4 of Appendix C.

${ }^{26}$ Creation of wholesale electricity markets can also affect renewable generation. Dahlke (2018) finds that the start of the Midcontinent Independent System Operator (MISO) wholesale market is associated with an increase in wind generation in the Midwest. Unfortunately, nationwide data for wholesale electricity market trading volumes are available from the EIA only from 2001 to the present, not for our study period from 1990 - 2015.

${ }^{27}$ Greenstone and Nath (2020) employ the same empirical approach to assess the pre-treatment trends between states with and without RPS as well as to tease out the effects of the policy adoption on key outcome variables, such as electricity price and electricity generation. Our additional outcomes are carbon dioxide emissions and renewable electricity generations from intermittent and dispatchable sources.
} 
or did not adopt the policy during the sample period from 1990 to 2015. We construct a series of indicator variables for the number of years before and after each state adopted the policy. The indicator PostRPS $S_{i t}^{k}$ is one if, in period $t$, state $i$ adopted the policy $k$ years later (or, if $k$ is negative, it is one if state $i$ had adopted the policy $-k$ years earlier). The dependent variable is an outcome $Y_{i t}$ such as electricity price, per capita $\mathrm{CO}_{2}$ emissions, or per capita electricity generation. We regress $Y_{i t}$ on event indicators:

$$
Y_{i t}=\sum_{k=-7, k \neq-1}^{12} \rho_{k} \text { PostRPS } k+\gamma_{i}+\delta_{t}+\epsilon_{i t}
$$

where $k$ runs from seven years before adoption to 12 years after adoption. PostRPS $S_{i t}^{-7}$ is one if, in period $t$, state $i$ had adopted the RPS 7 or more years earlier, and PostRPS $S_{i t}^{12}$ is one if, in period $t$, state $i$ enrolled 12 or more years later. ${ }^{28}$ The equation omits PostRPS $S_{i t}^{-1}$ for $k=-1$ (one year before adoption). Thus, the coefficients of interest are $\rho_{k}$, capturing effects of RPS adoption on outcome $Y_{i t}$ compared to the year before adoption. We control for state fixed effects $\gamma_{i}$ and time fixed effects $\delta_{t}$, and we cluster the standard errors by state.

A recent and emerging literature on event studies with staggered adoption finds that twoway fixed-effects difference-in-differences estimates are subject to potential biases in cases with heterogenous treatment effects either across groups or over time. Several papers propose alternative estimators to overcome these potential biases (Athey and Imbens, 2018; GoodmanBacon, 2018; Sun and Abraham, 2020; Callaway and Sant'Anna, 2020; Baker et al., 2021). For a robustness check, our Appendix C implements the Callaway and Sant'Anna (2020) estimator and shows graphical results. Patterns are similar to our Figure 1, though estimates are less precise.

Figure 1 portrays event-study results by plotting vertically the estimated coefficients $\rho^{k}$, showing the change relative to the year before adoption for (a) electricity price; (b) logged per capita emissions; and logged per capita electricity generation from (c) fossil fuels, (d) dispatchable renewables, and (e) intermittent renewables. Each horizontal axis shows the year. ${ }^{29}$ The solid lines represent point estimates, while the dashed lines indicate 95\% confidence

\footnotetext{
${ }^{28}$ In our sample, the first state adopted RPS in 1997, and the last state adopted the policy in 2009. We have a balanced panel of 26 years, so varying event dates mean that our panel is unbalanced in event time. Not all states in our sample have information for the full seven lead and twelve lag years of the event study window. To create a balanced panel in event time, we bin up two endpoints of -7 and +6 . We show results with balanced panel in event time in Appendix C. For more robustness checks, we vary the first endpoint from -18 to -7 and the other endpoint from 6 to 18. The results change little across all pairs of endpoints. Results can be provided upon request.

${ }^{29}$ We exclude estimates for the two binned endpoints.
} 
intervals. All point estimates of $\rho^{k}$ in the years before adoption are not significantly different from zero, which provides some suggestive evidence that the outcome's pre-treatment trends are similar between states with and without an RPS. Figure 1(a) for electricity price shows that all point estimates after adoption are positive, but they are not statistically significant until after the sixth year. All point estimates for emissions are negative, and those after the fourth year are statistically significant. In contrast, Figure 1 shows that RPS adoption has no significant effects on intermittent or dispatchable renewable generation. ${ }^{30}$ Although effects of RPS adoption are not the focus of our paper, these results are consistent with our analytical findings that the RPS has an unambiguous effect on reducing emissions but ambiguous impacts on renewables.

\section{Empirical Analysis of RPS Ratios}

\section{Empirical Strategy}

Our analytical model focuses not on RPS adoption, but on variations in the RPS ratio and how key parameters drive the effects on emissions and renewable energy. We now examine whether U.S. state-year panel data from 1990 to 2015 are consistent with our analytical findings. We use a standard fixed-effect estimating equation as our main specification: ${ }^{31}$

$$
Y_{i t}=\beta_{\text {eta }} e t a_{i t}+\beta_{Z} Z_{i t}+\beta_{\text {etaZ }}\left(e t a_{i t} \times Z_{i t}\right)+\beta_{V} V_{i t}+\mu_{i}+\lambda_{t}+\epsilon_{i t}
$$

where subscripts refer to state $i$ and year $t$. The dependent variable is an outcome $Y_{i t}$ such as electricity price, per capita $\mathrm{CO}_{2}$ emissions, or per capita electricity generation. Then et $a_{i t}$ is the RPS requirement ( $\eta$ in our model above). A set of covariates, $Z_{i t}$, includes key factors that might be associated with effects of the RPS (e.g. renewable endowments and renewable intermittency). Those factors are suggested by our analytical model, so we add interaction terms $\left(e t a_{i t} \times Z_{i t}\right)$. Then the signs and magnitudes of the coefficients $\beta_{\text {etaz }}$ indicate the validity of our hypotheses. Finally, we include a set of control variables $V_{i t}$, as discussed in Section 4. Time-invariant state fixed effects are captured by $\mu_{i}$, a vector of year dummies is in $\lambda_{t}$, and the idiosyncratic error term $\epsilon_{i t}$ captures unobserved characteristics. Standard errors are clustered by state.

\footnotetext{
${ }^{30}$ Many observations of intermittent renewable electricity are zero, so we use the inverse hyperbolic sine transformation instead of the log form in Figure 1 and later for this dependent variable.

31 This reduced-form linear equation estimates the average effect of the policy and not the possibly nonlinear effect of tightening the RPS requirement in a state that already has a tight standard. In contrast, our analytical model does capture the possibility that marginal cost rises with stringency. This nonlinear effect could be captured in estimation using the square of the policy renewable requirement, but the renewable requirement's possible endogeneity would become more of a problem if it were entered nonlinearly in the regression.
} 
Causal inferences from the above regression equation require strong assumptions on the conditional exogeneity of both the state RPS renewable requirement and key state characteristics. The standard fixed-effect model controls for all observed and unobserved time-invariant and state-specific confounders, but unobserved time-varying confounding factors can potentially result in omitted-variable bias that depends on correlations between omitted variables and the policy variable. We did provide some suggestive evidence on the parallel trend in outcomes between RPS and non-RPS states in Figure 1, but we cannot prove it. Finding a valid and strong instrument for RPS policy is the best way to deal with omitted-variable bias, of course, but the task is challenging. A valid instrument must be correlated with the policy but not influence the outcome. Candidates that satisfy the first condition include state political ideology or potential renewable resources. For example, studies show that states with lower Republican representation or with more renewable potential are more likely to adopt the RPS. ${ }^{32}$ Both of these candidate instruments fail the second condition, however, as they have unobserved effects on other state legislation and thus on economic outcomes like emissions. Using an instrument that is weak or invalid can be worse than the omitted variables bias itself (Angrist and Pischke, 2009).

While the fixed-effect model does not remove all biases from unobserved, timedependent, state-level factors, at least it removes biases from any time-invariant and statespecific confounders. ${ }^{33}$ Even without guarantees of causality, however, we provide some evidence on whether empirical results are consistent with our theory. Rather than try to prove our model is the "right" model, we can show it makes valid suggestions about what state characteristics might be driving results. Although the theorems derived from the analytical model are causal, our hypotheses are not. Our empirical analysis then shows that those hypotheses are consistent with the model.

\section{The RPS Requirement and Electricity Price}

Here we present empirical evidence on our hypotheses about how state characteristics are related to effects of tightening a state RPS. Table 1 summarizes the three hypotheses, and Table

\footnotetext{
32 Factors determining a state's choice about adopting an RPS are studied in the prior literature (Huang et al., 2007; Matisoff, 2008; Chandler, 2009; Lyon and Yin, 2010).

${ }^{33}$ In fact, none of the papers in the previous RPS literature can completely address the problem of non-random policy adoption. Most of them are based on the standard fixed effects and difference-in-difference empirical models. One exception is Hollingsworth and Rudik (2018), which can avoid this problem by studying how an RPS affects other states' emissions instead of in-state emissions.
} 
3 reports results of estimating the fixed-effects equation, where the dependent variable is average electricity price across all sectors. ${ }^{34}$

Our coefficients of interest are on interactions between key state-specific factors and the RPS requirement (r-rps). The third and fourth rows of Table 3 show estimates for the interaction of $r$-rps with state intermittent and dispatchable renewable endowments ( $Q_{I}$ and $Q_{D}$ in the GE model), proxied here by measured renewable potential (i-rep and $d$-rep, respectively). Our first hypothesis predicts a positive effect of $r$-rps $\times i$-rep on electricity price in the third row, but the positive estimated coefficients are tiny and insignificant. Our second hypothesis finds better support in the estimated coefficients on $r$-rps $\times d$-rep that are not only negative but statistically significant at $1 \%$ in both columns. ${ }^{35}$ Thus, any positive relation between an increase in the RPS ratio and electricity price is smaller in states with more dispatchable potential. This empirical result is in line with the analytical model's result: states with more dispatchable potential can meet the renewable requirement with less use of the more costly intermittent generation.

As shown in the last row of Table 3, the two estimates of the interaction between the RPS requirement and state wind intermittency ( $r$-rps $\times w$-inter) are both positive and are marginally statistically significant at the $10 \%$ level. So, the RPS requirement is more positively related to electricity price in states with greater intermittency of their wind. This result is consistent with our third theorem and hypothesis. A higher degree of renewable intermittency increases the cost of generating and integrating renewable electricity.

\section{The RPS Requirement and Carbon Dioxide Emissions}

Table 4 shows empirical evidence for all three hypotheses regarding changes in $\mathrm{CO}_{2}$ emissions. The dependent variable in the first two columns is the logged per capita state $\mathrm{CO}_{2}$ emissions from all sectors. The dependent variable in last two columns (3) and (4) is logged per capita emissions from the electricity sector only. ${ }^{36}$

\footnotetext{
${ }^{34}$ Appendix $\mathrm{C}$ also shows results with a separate dependent variable for each sector's average electricity price (residential, industrial, and commercial sectors). Results are similar to those reported in Table 3.

${ }^{35}$ Column 1 includes the adoption dummy a-rps, and column 2 does not. Many studies in the prior literature examine the effect of RPS adoption and use $a-r p s$ as the key explanatory variable. Our paper focuses on effects of the policy requirement $r$-rps. This variable effectively captures policy adoption, because it is zero when a state has no policy. Thus, our preferred specification is column 2 with $r$-rps and not $a-r p s$, but we present column 1 with the adoption indicator $a-r p s$ to show that results are robust.

${ }^{36}$ The RPS policy focuses on emissions from the electricity sector, but our analytical model includes general equilibrium channels through which the policy affects not only emissions from the electricity sector but also from other sectors. Thus, we show empirical results for each outcome: emissions from all sectors or from electricity only.
} 
The first two columns show that estimated coefficients on the interaction of $r$-rps with the state intermittent renewable potential (i-rep) are all negative and marginally significant. Thus, the negative association between the RPS requirement and emissions is larger in states with greater $Q_{I}$ potential. The empirical results are in line with our first hypothesis that states with higher $Q_{I}$ endowments tend to use more expensive $R_{I}$ generation to meet RPS requirements. As a result of these higher costs, fossil-fuel generation and emissions are reduced by three effects highlighted in our GE model: the direct policy effect of the RPS, the negative income effect, and the negative substitution effect (between electricity and primary factors in production of $X$ ). At the same time, estimates of $r$-rps $\times d$-rep in columns (1) and (2) are all positive and statistically significant at the 5\% level. Thus, consistent with our second hypothesis, the direct policy effect of the RPS is positive for renewables, and the negative association between the RPS requirement and emissions is smaller in states with greater $Q_{D}$ potential.

Estimated coefficients on the interaction term between the renewable requirement and state wind intermittency ( $r$-rps $\times w$-inter) are negative and statistically significant at $5 \%$ and $1 \%$ levels. Greater renewable intermittency increases the cost of generating and integrating renewable electricity. This higher cost amplifies both the negative income effect and negative substitution effect on electricity consumption, leading to lower emissions. This result is consistent with our third theorem and hypothesis regarding $\mathrm{CO}_{2}$ emissions.

\section{The RPS Requirement and Renewable Electricity Generation}

In Table 5, the dependent variable in the first two columns is logged per capita fossil-fuel generation (electricity sector only). The dependent variable in columns (3) and (4) is logged per capita dispatchable renewable generation. ${ }^{37}$ The dependent variable in last two columns is the inverse hyperbolic sine transformation of per capita intermittent renewable generation.

Coefficients of interest are on the interactions of the RPS requirement $r$-rps with potential renewables (endowments) and wind intermittency. Consistent with our first hypothesis, negative estimates on $r$-rps $\times$ i-rep in all columns suggest that states with more intermittent potential have larger negative association between their RPS requirement and fossil fuel generation, and larger negative (or smaller positive) associations with both types of renewable generation. The negative

\footnotetext{
${ }^{37}$ Delaware is the only state that has zero renewable electricity generation in several years, so logs of the state's renewable electricity generation in those year are not defined and treated as missing observations. For a robustness check, we drop all data for Delaware to run all specifications in Table 5, and we find similar results.
} 
estimates for fossil-fuel electricity and dispatchable renewable electricity are statistically significant at 10\% and 5\% confidence levels, but the estimates for intermittent renewable electricity are not statistically significant.

Estimates on $r$-rps $\times d$-rep are positive in all columns as predicted by our second hypothesis. They are statistically significant at the 5\% level for fossil-fuel generation and at the $1 \%$ confidence level for $R_{I}$ generation, but not significant for $R_{D}$ generation. States with greater dispatchable renewable potential $\left(Q_{D}\right)$ can avoid the more costly intermittent renewable development, so the smaller negative income effect of a tighter RPS means it is associated with less reduction in $F$ and more increases in both $R_{I}$ and $R_{D}$ generation. ${ }^{38}$

Estimates on $r$-rps $\times w$-inter are negative as predicted by our third hypothesis. ${ }^{39}$ They are statistically significant for fossil-fuel and dispatchable renewable electricity but not for intermittent renewable electricity. Greater intermittency of renewable resources implies higher compliance cost, so that a raised RPS requirement has stronger negative income and substitution effects that reduce all kinds of electricity generation.

\section{Conclusion}

We build a new analytical general equilibrium model to study key state characteristics that help determine the effects of RPS on carbon dioxide emissions and renewable energy. Our analytical model allows us to decompose the effects of RPS into different components. We show the mechanisms behind each state outcome and the reasons for heterogeneity of these outcomes across states. Our analytical model explains why empirical papers have found significant effects of RPS on $\mathrm{CO}_{2}$ emissions but mixed evidence on renewable generation. This ambiguous effect suggests a possible trade-off between emissions reduction and renewable generation goals. Our model adds to this literature by showing that the general equilibrium income effect is a key determinant of such results.

The analytical findings paint a clear picture of whether and how an increase in RPS requirement affects each state outcomes, including electricity price, emissions, fossil fuel electricity, and renewable electricity. The intermittent characteristic of renewable sources can

\footnotetext{
38 The result that having more $Q_{D}$ potential can make states respond to higher RPS requirements by using more $R_{I}$ generation may seem odd, but those states may already be making extensive use of their high $Q_{D}$ endowment. If so, then a raised RPS requirement can induce them to start up the rising marginal cost curve for $R_{I}$ generation.

${ }^{39}$ In Appendix C, we vary the set of control variables to examine if our choice of controls affects the results. The signs of key coefficients are the same as in Tables 3 - 5, and their magnitudes are not much different.
} 
drive the cost of renewable electricity to exceed the cost of fossil-fuel electricity. Our model demonstrates how these cost differences are crucial in explaining the effects of a higher RPS requirements on key outcomes. An RPS policy that requires the production of costlier renewable electricity has negative income effects on all kinds of electricity generation, but direct policy effects that reduce fossil fuel generation (making that reduction unambiguous) and increase renewable generation (making that reduction ambiguous).

In addition, our analytical model yields theorems about state characteristics that help determine the signs and magnitudes of the impacts of RPS. We prove these causal relationships from the analytical GE model, and we use these theorems to develop hypotheses about likely correlations in the data. We then use publicly available U.S. state-level data from 1990 to 2015 to show how empirical evidence supports the analytical findings. In states with more intermittent renewable potential or with more renewable intermittency, the association between RPS policy and renewable generation is less positive or more negative, but the negative association with emissions is larger. Those relationships reverse in states with greater dispatchable renewable potential. Our paper demonstrates that analytically tractable general equilibrium models can provide useful and insightful guidance to empirical investigations.

Both our analytical and empirical results help inform policymakers who want to re-assess existing RPS policies. While the policy can unambiguously help a state reduce emissions, we show how its effect on encouraging renewable generation depends on the state-specific cost of producing, integrating, and transmitting renewable electricity relative to the cost of fossil fuel electricity. If a state's relative endowments mean that the cost of renewable electricity is much higher than the cost of fossil fuel electricity generation, then imposing a high RPS requirement might backfire and reduce renewable generation.

\section{References}

Angrist, Joshua D., and Jörn-Steffen Pischke. 2009. Mostly Harmless Econometrics: An Empiricist's Companion. Princeton: Princeton University Press.

Athey, Susan, and Guido W. Imbens. 2018. Design-based analysis in difference-in-differences settings with staggered adoption. NBER Working Paper No. 24963. Retrieved from https://www.nber.org/system/files/working_papers/w24963/w24963.pdf.

Baker, Andrew, David F. Larcker, and Charles C.Y. Wang. 2021. How much should we trust staggered difference-in-differences Eetimates? Working Paper. Retrieved from https://papers.ssrn.com/sol3/papers.cfm?abstract_id=3794018. 
Bento, Antonio M., Teevrat Garg, and Daniel Kaffine. 2018. Emissions reductions or green booms? General equilibrium effects of a renewable portfolio standard. Journal of Environmental Economics of Management 90: 78-100.

Borenstein, Severin. 2008. The market value and cost of solar photovoltaic electricity production. CSEM Working Paper 176. Retrieved from https://haas.berkeley.edu/wp-content/uploads/csemwp176.pdf.

Boretti, Alberto and Stefania Castelletto. 2020. Cost of wind energy generation should include energy storage allowance. Scientific Reports 2978: 1-13.

Callaway, Brantly, and Pedro H.C. Sant'Anna. 2020. Difference-in-differences with multiple time periods. Journal of Econometrics. https://doi.org/10.1016/j.jeconom.2020.12.001.

Chandler, Jess. 2009. Trendy solutions: Why do states adopt sustainable energy portfolio standards? Energy Policy 37 (8): 3274-3281.

Covert, Thomas, Michael Greenstone, and Christopher R. Knittel. 2016. Will we ever stop using fossil fuels? Journal of Economic Perspectives 30 (1): 117-138.

Cullen, Joseph. 2013. Measuring the environmental benefits of wind-generated electricity. American Economic Journal: Economic Policy 5 (4): 107-133.

Dahlke, Steve.2018. Effects of wholesale electricity markets on wind generation in the midwestern United States. Energy Policy 122: 358-368.

Delmas, Magali A., and Maria J. Montes-Sancho. 2011. U.S. state policies for renewable energy: Context and effectiveness. Energy Policy 39 (5): 2273- 2288.

Denholm, Paul, and Robert M. Margolis. 2007. Evaluating the limits of solar photovoltaics (PV) in traditional electric power systems. Energy Policy 35 (5): 2852- 2861.

Fell, Harrison, Daniel Kaffine, and Daniel Steinberg. 2017. Energy efficiency and emissions intensity standards. Journal of Association of Environmental and Resource Economists 4 (S1): S201- S226.

Fischer, Carolyn. 2010. Renewable portfolio standards: When do they lower energy prices? Energy Journal 31 (1): 101-119.

Fischer, Carolyn, and Richard G. Newell. 2008. Environmental and technology policies for climate mitigation. Journal of Environmental Economics and Management 55 (2): 142162.

Gowrisankaran, Gautam, Stanley S. Reynolds, and Mario Samano. 2016. Intermittency and the value of renewable energy. Journal of Political Economy 124 (4): 1187-1234.

Goodman-Bacon, Andrew. 2018. Difference-in-differences with variation in treatment timing. NBER Working Paper No. 25018. Retrieved from https://www.nber.org/papers/w25018. 
Greenstone, Michael, and Ishan Nath. 2020. Do renewable portfolio standards deliver costeffective carbon abatement? Working Paper 2019-62, Chicago, IL: Becker Friedman Institute for Economics at the University of Chicago. Retrieved from https://bfi.uchicago.edu/wp-content/uploads/2020/11/BFI_WP_201962.pdf.

Hitaj, Claudia. 2013. Wind power development in the United States. Journal of Environmental Economics and Management 65: 394-410.

Holland, Stephen P., Jonathan E. Hughes, and Christopher R. Knittel. 2009. Greenhouse gas reduction under low carbon fuel standards. American Economic Journal: Economic Policy 1 (1): 106-146.

Hollingsworth, Alex and Ivan Rudik. 2018. External impacts of local energy policy: The case of Renewable Portfolio Standards. Journal of the Association of Environmental and Resource Economists 6 (1): 187-213.

Huang, Ming-Yuan, Janaki R.R. Alavalapati, Douglas R. Carter, and Matthew H. Langholtz. 2007. Is the choice of renewable portfolio standards random? Energy Policy 35 (11): 5571-5575.

Joskow, Paul L. 2011. Comparing the costs of intermittent and dispatchable electricity generating technology. American Economic Review 101 (3): 238-241.

Logan, Jeffrey, Patrick Sullivan, Walter Short, Lori Bird, Ted L. James, and Monisha R. Shah. 2009. Evaluating a Proposed 20\% National Renewable Portfolio Standard. Technical Report NREL/TP-6A2-45161. Retrieved from http://www.nrel.gov/docs/fy09osti/45161.pdf.

Lyon, Thomas P. 2016. Drivers and impacts of renewable portfolio standards. Annual Review of Resource Economics 8 (1): 141-155.

Lyon, Thomas P., and Haitao Yin. 2010. Why do states adopt renewable portfolio standards?: An empirical investigation. Energy Journal 31 (3): 133-157.

Matisoff, Daniel C. 2008. The adoption of state climate change policies and renewable portfolio standards: Regional diffusion or internal determinants. Review of Policy Research 25 (6): 527-546.

Menz, Fredric C., Stephan Vachon. 2006. The effectiveness of different policy regimes for promoting wind power: Experiences from the states. Energy Policy 34 (14):1786-1796.

Rausch, Sebastian, and Matthew Mowers. 2014. Distributional and efficiency impacts of clean and renewable energy standards for electricity. Resource and Energy Economics 36 (2): 556-85.

Ren, Guorui, Jinfu Liu, Jie Wan, Yufeng Gue, and Daren Yu. 2017. Overview of wind power intermittency: Impacts, measurements, and mitigation solutions. Applied Energy 204: 4765. 
Ryan, Wiser, Galen Barbose, Jenny Heeter, Trieu Mai, Lori Bird, Mark Bolinger, Alberta Carpenter, and Garvin Heath. 2016. A prospective analysis of the costs, benefits and impacts of U.S. Renewable Portfolio Standards. Technical Report NREL/TP-6A2067455. Retrieved from https://www.nrel.gov/docs/fy17osti/67455.pdf.

Sun, Liyang, and Sarah Abraham. 2020. Estimating dynamic treatment effects in event studies with heterogeneous treatment effects. Journal of Econometrics. https://doi.org/10.1016/j.jeconom.2020.09.006.

Upton, Gregory B. Jr., and Brian F. Snyder. 2017. Funding renewable energy: An analysis of renewable portfolio standards. Energy Economics 66: 205-216.

Yin, Haitao, and Nicholas Powers. 2010. Do state renewable portfolio standards promote in-state renewable generation? Energy Policy 38 (2): 1140-1149. 
Table 1: Summary of Hypotheses about the Signs of Empirical Results

\begin{tabular}{|c|c|c|c|c|c|}
\hline & $\begin{array}{c}\text { Electricity } \\
\text { Price } \\
\widehat{P_{E}}\end{array}$ & $\begin{array}{c}\text { Carbon } \\
\text { Emissions } \\
\hat{C}\end{array}$ & $\begin{array}{c}\text { Fossil- } \\
\text { Fuel } \\
\hat{F}\end{array}$ & $\begin{array}{c}\text { Dispatchable } \\
\text { Renewables } \\
\widehat{R_{D}}\end{array}$ & $\begin{array}{c}\text { Intermittent } \\
\text { Renewables } \\
\widehat{R_{I}}\end{array}$ \\
\hline Overall impact of increased requirement & + & - & - & $+/-$ & $+/-$ \\
\hline \multicolumn{6}{|c|}{ Effect of parameters on each impact (sign of derivatives) } \\
\hline H1: $Q_{I} \equiv$ Intermittent endowment & + & - & - & - & - \\
\hline H2: $Q_{D} \equiv$ Dispatchable endowment & - & + & + & + & + \\
\hline $\begin{array}{r}\text { H3: } \alpha_{I \eta} \equiv \text { elasticity of productivity } \\
A_{I} \text { w.r.t. RPS requirement } \eta\end{array}$ & - & + & + & + & + \\
\hline
\end{tabular}


Table 2: Summary Statistics

\begin{tabular}{|c|c|c|c|c|}
\hline Variable & Mean & Std.Dev. & Min & Max \\
\hline Electricity price (cents/kWh) & 7.930 & 2.678 & 3.370 & 18.07 \\
\hline $\mathrm{CO}_{2}$ emissions (millions of metric tons) & 103.0 & 79.44 & 5.490 & 404.8 \\
\hline Fossil-fuel electricity (terawatt-hours) & 48.80 & 38.70 & 0.004 & 204.0 \\
\hline Dispatchable renewable electricity (terawatt-hours) & 7.144 & 14.59 & 0.000 & 105.2 \\
\hline Intermittent renewable generation (terawatt-hours) & 0.724 & 2.058 & 0.000 & 27.04 \\
\hline Population (millions) & 5.686 & 6.080 & 0.454 & 40.57 \\
\hline Per capita $\mathrm{CO}_{2}$ emissions (metric tons) & 23.80 & 19.02 & 8.080 & 132.6 \\
\hline Per capita dispatchable renewable elec. (megawatt-hours) & 1,895 & 3,162 & 0.000 & 18,536 \\
\hline Per capita intermittent renewable elec. (megawatt-hours) & 232.9 & 852.3 & 0.000 & 449 \\
\hline RPS adoption (0/1) & 0.269 & 0.444 & 0 & 1 \\
\hline RPS percentage requirement fraction ( 0 to 1 ) & 0.019 & 0.050 & 0.000 & 0.366 \\
\hline RPS credit multiplier $(0 / 1)$ & 0.130 & 0.337 & 0 & 1 \\
\hline RPS carve-out $(0 / 1)$ & 0.131 & 0.337 & 0 & 1 \\
\hline RPS alternative compliance payments (0/1) & 0.154 & 0.361 & 0 & 1 \\
\hline RPS REC trading & 0.269 & 0.444 & 0 & 1 \\
\hline Dispatchable renewable potential (gigawatt-hours) & 12.94 & 1.136 & 9.407 & 14.33 \\
\hline Intermittent renewable potential (gigawatt-hours) & 6.536 & 0.731 & 4.782 & 7.539 \\
\hline Wind intermittency (\%) & 20.37 & 23.91 & 17.00 & 27.00 \\
\hline Heating degree days & 5,286 & 2,058 & 430.0 & 10,810 \\
\hline Cooling degree days & 1,043 & 782.5 & 42.00 & 4,147 \\
\hline House League of Conservation Voters scores (0 to 100) & 45.89 & 26.09 & 0 & 100 \\
\hline Senate League of Conservation Voters scores ( 0 to 100 ) & 49.25 & 33.40 & 0 & 100 \\
\hline Natural gas price (dollars per thousand cubic feet) & 5.095 & 2.179 & 1.460 & 13.47 \\
\hline Electricity import as a fraction of electricity sales ( 0 to 1 ) & 0.250 & 0.600 & -3.035 & 0.827 \\
\hline Restructured electricity market $(0 / 1)$ & 0.238 & 0.426 & 0 & 1 \\
\hline Corporate tax incentive $(0 / 1)$ & 0.161 & 0.368 & 0 & 1 \\
\hline Public benefits fund (0/1) & 0.289 & 0.454 & 0 & 1 \\
\hline Energy efficiency standard $(0 / 1)$ & 0.165 & 0.371 & 0 & 1 \\
\hline Citizen ideology (0 to 100 ) & 49.78 & 15.08 & 8.450 & 95.97 \\
\hline State ideology (0 to 100) & 47.49 & 14.41 & 17.51 & 73.62 \\
\hline
\end{tabular}

Notes: Our data cover 46 states for 26 years from 1990 to 2015, so the number of observations is 1,196 for most variables; data on renewable potential and wind intermittency vary across 46 states but do not change over time. 
Table 3: Estimated Determinants of How RPS Requirements Relate to Electricity Price

\begin{tabular}{|c|c|c|}
\hline \multirow[b]{2}{*}{ Independent variables } & \multicolumn{2}{|c|}{ Electricity Price } \\
\hline & $(1)$ & $(2)$ \\
\hline$a-r p s$ & $\begin{array}{c}0.11 \\
(0.18)\end{array}$ & \\
\hline$r$-rps & $\begin{array}{c}23.5 \\
(26.0)\end{array}$ & $\begin{array}{c}23.0 \\
(26.4)\end{array}$ \\
\hline$r$-rps $\times i-r e p$ & $\begin{array}{c}0.03 \\
(2.13)\end{array}$ & $\begin{array}{c}0.14 \\
(2.13)\end{array}$ \\
\hline$r$-rps $\times d$-rep & $\begin{array}{c}-5.44 \\
(1.76)\end{array}$ & $\begin{array}{c}-5.51 \\
(1.73)\end{array}$ \\
\hline$r$-rps $\times w$-inter & $\begin{array}{c}17.4 \\
(9.59)\end{array}$ & $\begin{array}{c}17.8 \\
(9.71)\end{array}$ \\
\hline Mean dependent variable & 7.93 & 7.93 \\
\hline Observations & 1196 & 1196 \\
\hline State fixed effects & Yes & Yes \\
\hline Time fixed effects & Yes & Yes \\
\hline Adj R-squared & 0.84 & 0.84 \\
\hline
\end{tabular}

Notes: The dependent variable is average electricity price across all sectors. Variables of interests are the interaction of the policy renewable requirement $(r$-rps) with the state intermittent renewable potential (i-rep), the state dispatchable renewable potential (d-rep), and the state wind intermittency ( $w$-inter). Variable $a$-rps indicates whether the state adopts an RPS. Robust standard errors in parentheses are clustered at the state level. 
Table 4: Estimated Determinants of How RPS Requirements Relate to $\mathrm{CO}_{2}$ Emissions

\begin{tabular}{|c|c|c|c|c|}
\hline \multirow[b]{2}{*}{ Independent variables } & \multicolumn{2}{|c|}{$\begin{array}{c}\text { All Sectors } \\
\mathrm{CO}_{2} \text { Emissions }\end{array}$} & \multicolumn{2}{|c|}{$\begin{array}{l}\text { Electricity Sector } \\
\mathrm{CO}_{2} \text { Emissions }\end{array}$} \\
\hline & (1) & (2) & (3) & (4) \\
\hline$a-r p s$ & $\begin{array}{c}-0.01 \\
(0.02)\end{array}$ & & $\begin{array}{c}0.01 \\
(0.04)\end{array}$ & \\
\hline$r$-rps & $\begin{array}{c}8.63 \\
(5.45)\end{array}$ & $\begin{array}{c}8.70 \\
(5.32)\end{array}$ & $\begin{array}{c}19.2 \\
(9.99)\end{array}$ & $\begin{array}{c}19.2 \\
(10.0)\end{array}$ \\
\hline$r$-rps $\times i$-rep & $\begin{array}{c}-0.38 \\
(0.20)\end{array}$ & $\begin{array}{l}-0.40 \\
(0.20)\end{array}$ & $\begin{array}{c}-0.50 \\
(0.68)\end{array}$ & $\begin{array}{l}-0.49 \\
(0.68)\end{array}$ \\
\hline$r$-rps $\times d$-rep & $\begin{array}{c}0.45 \\
(0.21)\end{array}$ & $\begin{array}{c}0.47 \\
(0.22)\end{array}$ & $\begin{array}{c}1.04 \\
(0.77)\end{array}$ & $\begin{array}{c}1.03 \\
(0.78)\end{array}$ \\
\hline$r$-rps $\times w$-inter & $\begin{array}{c}-4.20 \\
(1.77)\end{array}$ & $\begin{array}{c}-4.26 \\
(1.72)\end{array}$ & $\begin{array}{c}-10.0 \\
(3.04)\end{array}$ & $\begin{array}{c}-9.99 \\
(3.05)\end{array}$ \\
\hline Mean dependent variable & 3.00 & 3.00 & 1.98 & 1.98 \\
\hline Observations & 1196 & 1196 & 1157 & 1157 \\
\hline State fixed effects & Yes & Yes & Yes & Yes \\
\hline Time fixed effects & Yes & Yes & Yes & Yes \\
\hline Adj R-squared & 0.70 & 0.70 & 0.45 & 0.45 \\
\hline
\end{tabular}

Notes: The dependent variable in columns (1) and (2) is the logged total carbon dioxide emissions per capita. The dependent variable in columns (3) and (4) is the logged per capita carbon dioxide emissions from electricity sector only. Variables of interests are the interaction of the policy renewable requirement $(r-$ $r p s$ ) with the state intermittent renewable potential (i-rep), the state dispatchable renewable potential ( $d$ rep), and the state wind intermittency (w-inter). Variable $a$-rps indicates whether the state adopts an RPS. Robust standard errors in parentheses are clustered at the state level. 
Table 5: Estimated Determinants of How RPS Requirements Relate to Electricity

\begin{tabular}{|c|c|c|c|c|c|c|}
\hline \multirow[b]{2}{*}{ Independent variables } & \multicolumn{2}{|c|}{$\begin{array}{l}\text { Fossil-Fuel } \\
\text { Electricity }\end{array}$} & \multicolumn{2}{|c|}{$\begin{array}{c}\text { Dispatchable } \\
\text { Renewable Electricity }\end{array}$} & \multicolumn{2}{|c|}{$\begin{array}{c}\text { Intermittent } \\
\text { Renewable Electricity }\end{array}$} \\
\hline & $(1)$ & $(2)$ & (3) & (4) & $(5)$ & (6) \\
\hline$a-r p s$ & $\begin{array}{l}-0.03 \\
(0.06)\end{array}$ & & $\begin{array}{c}0.04 \\
(0.04)\end{array}$ & & $\begin{array}{c}0.85 \\
(0.51)\end{array}$ & \\
\hline$r$-rps & $\begin{array}{l}20.4 \\
(9.67)\end{array}$ & $\begin{array}{c}20.6 \\
(9.80)\end{array}$ & $\begin{array}{c}11.2 \\
(4.33)\end{array}$ & $\begin{array}{l}11.0 \\
(4.14)\end{array}$ & $\begin{array}{l}-34.2 \\
(85.1)\end{array}$ & $\begin{array}{l}-38.6 \\
(86.8)\end{array}$ \\
\hline$r$-rps $\times i$-rep & $\begin{array}{l}-1.48 \\
(0.59)\end{array}$ & $\begin{array}{l}-1.52 \\
(0.61)\end{array}$ & $\begin{array}{l}-1.01 \\
(0.48)\end{array}$ & $\begin{array}{l}-0.95 \\
(0.50)\end{array}$ & $\begin{array}{l}-4.00 \\
(3.49)\end{array}$ & $\begin{array}{l}-2.67 \\
(3.96)\end{array}$ \\
\hline$r$-rps $\times d$-rep & $\begin{array}{l}1.24 \\
(0.51)\end{array}$ & $\begin{array}{l}1.26 \\
(0.51)\end{array}$ & $\begin{array}{c}0.63 \\
(0.45)\end{array}$ & $\begin{array}{c}0.59 \\
(0.45)\end{array}$ & $\begin{array}{c}8.60 \\
(2.62)\end{array}$ & $\begin{array}{l}7.64 \\
(2.78)\end{array}$ \\
\hline$r$-rps $\times w$-inter & $\begin{array}{l}-8.87 \\
(3.28)\end{array}$ & $\begin{array}{l}-8.97 \\
(3.34)\end{array}$ & $\begin{array}{l}-4.34 \\
(1.44)\end{array}$ & $\begin{array}{l}-4.17 \\
(1.40) \mathrm{e}\end{array}$ & $\begin{array}{l}-17.5 \\
(24.8)\end{array}$ & $\begin{array}{l}-13.4 \\
(25.5)\end{array}$ \\
\hline Mean Dependent variable & 8.95 & 8.95 & 6.30 & 6.30 & 2.08 & 2.08 \\
\hline Observations & 1196 & 1196 & 1170 & 1170 & 1196 & 1196 \\
\hline State fixed effects & Yes & Yes & Yes & Yes & Yes & Yes \\
\hline Year fixed effects & Yes & Yes & Yes & Yes & Yes & Yes \\
\hline Adj R-squared & 0.25 & 0.25 & 0.29 & 0.29 & 0.68 & 0.68 \\
\hline
\end{tabular}

Notes: The dependent variable in columns (1) and (2) is the logged fossil-fuel electricity generation per capita. The dependent variable in columns (3) and (4) is the inverse hyperbolic sine transformation of intermittent renewable electricity generation per capita. The dependent variable in columns (5) and (6) is the logged dispatchable renewable electricity generation per capita. Variables of interests are the interaction of the policy renewable requirement $(r-r p s)$ with the state intermittent renewable potential (i-rep), the state dispatchable renewable potential ( $d$-rep), and the state wind intermittency ( $w$-inter). Variable $a$-rps indicates whether the state adopts an RPS. Robust standard errors in parentheses are clustered at the state level. 
Figure 1: Effects of RPS Adoption on Each Outcome Over Time

(a)

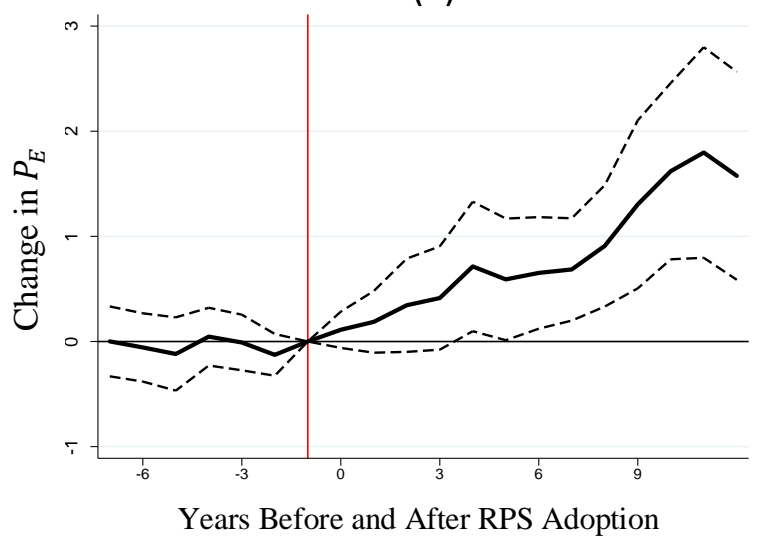

(c)

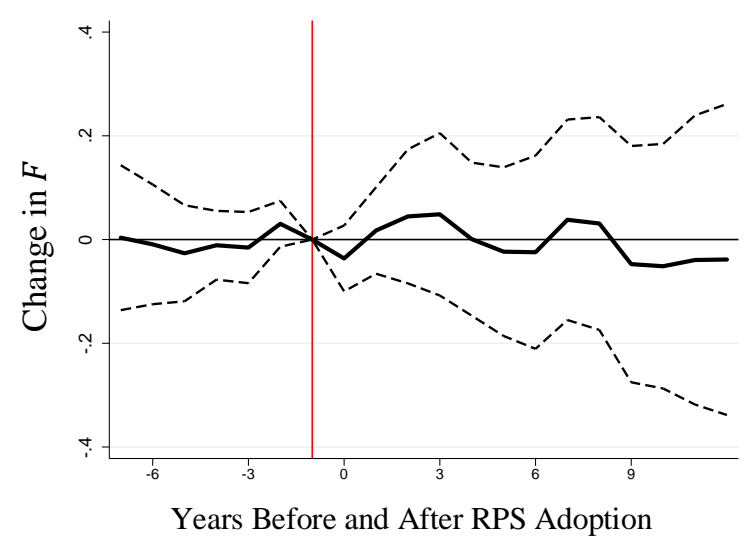

(e)

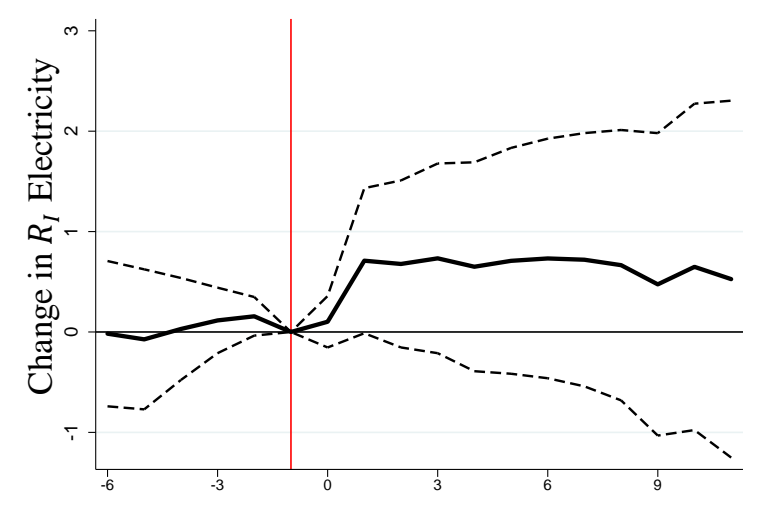

Years Before and After RPS Adoption

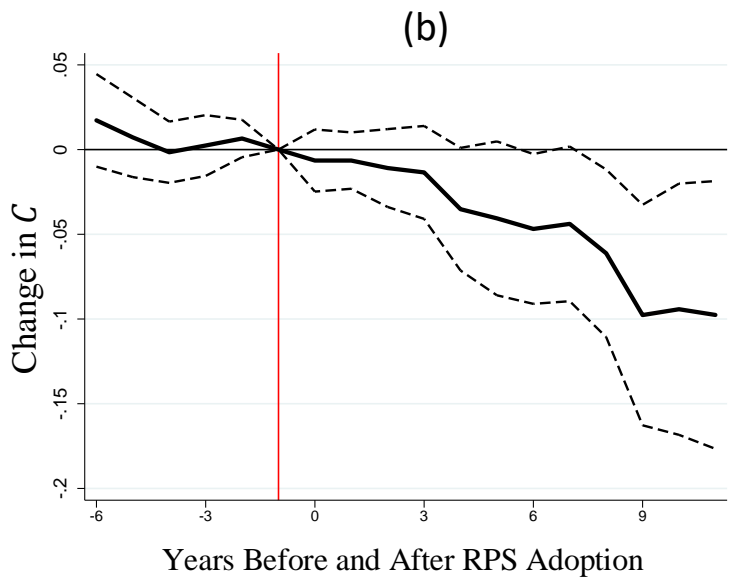

(d)

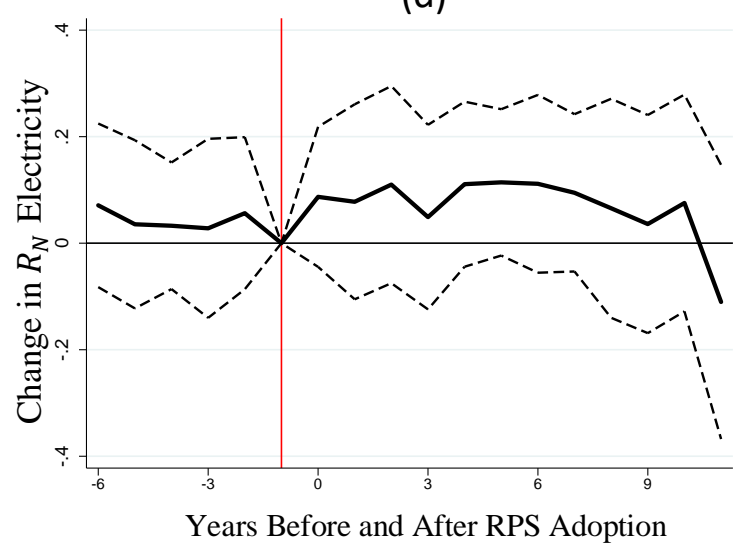

Notes: This figure illustrates the event-study regression results. The vertical axis shows change in electricity price in (a), change in logged total carbon dioxide emissions per capita in (b), change in logged fossil fuel electricity per capita in (c), change in logged dispatchable renewable electricity per capita in (d), and change in the inverse hyperbolic sine transformation of intermittent renewable electricity generation per capita in (e). The horizontal axis shows the number of years relative to the policy adoption. The solid line represents point estimates and the dashed line indicates 95\% confidence intervals. The standard errors are clustered at the state level. Controls include state and year fixed effects. 


\section{APPENDICES:}

\section{Appendix A: Solve for changes in emissions and energy use from an increase in RPS}

This appendix uses equations (14) - (27) in the text to solve for changes in prices and quantities that result from a tighter renewable energy standard $(\hat{\eta}>0)$. We want the closed-form expressions for $\hat{C}$ and $\hat{R}$ as a function of parameters and the policy shock $\hat{\eta}$. We find that the easiest way to solve this system of linearized equations is first to express variable changes in terms of $\hat{R}, \hat{\eta}$, and parameters. So, we manipulate equations (14), (15), (17), and (20) to get:

$$
\begin{aligned}
& \hat{E}=\hat{R}-\hat{\eta} \\
& \hat{F}=\hat{R}-\frac{1}{(1-\eta)} \hat{\eta} \\
& \widehat{R_{D}}=\hat{R}-\frac{b b_{\eta}}{(1-b)} \hat{\eta}
\end{aligned}
$$

From equations (15), (A.3), (21), (22), (26), (27), (19), and (A.2) we get expressions for changes in use of the primary factor $K$ in each sector:

$$
\begin{aligned}
& \widehat{K_{R I}}=\hat{R}+\left(b_{\eta}-\alpha_{I \eta}\right) \hat{\eta} \\
& \widehat{K_{R D}}=\hat{R}-\frac{b b_{\eta}}{(1-b)} \hat{\eta} \\
& \widehat{K_{F}}=\hat{R}-\frac{1}{(1-\eta)} \hat{\eta} \\
& \widehat{K_{E}}=\hat{R}-\left(\frac{\delta_{F}}{(1-\eta)}-\delta_{R I}\left(b_{\eta}-\alpha_{I \eta}\right)+\delta_{R D} \frac{b b_{\eta}}{(1-b)}\right) \hat{\eta} \\
& \widehat{K_{X}}=-\frac{\gamma_{E}}{\gamma_{X}} \hat{R}+\frac{\gamma_{E}}{\gamma_{X}}\left(\frac{\delta_{F}}{(1-\eta)}-\delta_{R I}\left(b_{\eta}-\alpha_{I \eta}\right)+\delta_{R D} \frac{b b_{\eta}}{(1-b)}\right) \hat{\eta}
\end{aligned}
$$

Second, we substitute the choice of numeraire $\left(\widehat{P_{K}}=0\right)$, (A.1), (A.4), and (A.5) into (24) and (25) to solve for the closed form expression of $\widehat{P_{E}}$ :

$$
\widehat{P_{E}}=\left(\delta_{R I}\left(1-A_{I}\right)+\delta_{R D}\left(1-A_{D}\right)\right) \hat{\eta}-\left(\delta_{R I} \alpha_{I \eta}+\delta_{R D}\right) \hat{\eta}+\left(1-\frac{A_{I}}{A_{D}}\right) \delta_{R I} b_{\eta} \hat{\eta}
$$

Then we express all changes in prices and outcomes in terms of parameters and change in electricity price $\widehat{P_{E}}$ as in equations (29) - (37) in the text. 


\section{Appendix B: Proofs of Theorems 1 - 3:}

From equations (34) - (37), we know that changes in carbon emissions and renewable electricity generation in response to the policy shock depends on how electricity price response to the shock. So, to prove the first two theorems, we first totally differentiate $\widehat{P_{E}}$ with respect to $Q_{I}$ and $Q_{D}$ and show that $\frac{\partial \widehat{P_{E}}}{\partial Q_{I}}>0$ and $\frac{\partial \widehat{P_{E}}}{\partial Q_{D}}<0$ as below.

Totally differentiate $\widehat{P_{E}}$ with respect to $Q_{I}$ to yield:

$$
\begin{gathered}
\frac{\partial \widehat{P_{E}}}{\partial Q_{I}}=\left(\frac{\partial \delta_{R I}}{\partial Q_{I}}\left(1-A_{I}-\alpha_{I \eta}\right)+\frac{\partial \delta_{R D}}{\partial Q_{I}}\left(1-A_{D}\right)\right) \hat{\eta} \\
+\left(1-\frac{A_{I}}{A_{D}}\right) \frac{\partial \delta_{R I}}{\partial Q_{I}} b_{\eta} \hat{\eta}
\end{gathered}
$$

Rewrite the expression for $\delta_{R D}$ and $\delta_{R I}$ as:

$$
\begin{gathered}
\frac{P_{E}}{P_{K}}=\frac{K_{E}}{E}=\frac{K_{R I}}{E}+\frac{K_{R D}}{E}+\frac{K_{F}}{E}=\frac{b \eta}{A_{I}}+\frac{(1-b) \eta}{A_{D}}+1-\eta \\
\delta_{R N}=\frac{K_{R D}}{K_{E}}=\frac{R_{D} P_{K}}{A_{D} K_{E} P_{K}}=\frac{(1-b) \eta E}{A_{D} E} \frac{P_{K}}{P_{E}}=\frac{(1-b) \eta}{A_{D}} \frac{P_{K}}{P_{E}}=\frac{(1-b) \eta}{A_{D}\left(\frac{b \eta}{A_{I}}+\frac{(1-b) \eta}{A_{D}}+1-\eta\right)} \\
\delta_{R I}=\frac{K_{R I}}{K_{E}}=\frac{R_{I} P_{K}}{A_{I} K_{E} P_{K}}=\frac{b \eta E}{A_{I} E} \frac{P_{K}}{P_{E}}=\frac{b \eta}{A_{I}} \frac{P_{K}}{P_{E}}=\frac{b \eta}{A_{I}\left(\frac{\beta \eta}{A_{I}}+\frac{(1-\beta) \eta}{A_{D}}+1-\eta\right)}
\end{gathered}
$$

Then totally differentiate $\delta_{R I}$ and $\delta_{R D}$ to get:

$$
\begin{aligned}
& \frac{\partial \delta_{R I}}{\partial Q_{I}}=\eta \frac{\left(\frac{\eta}{A_{D}}+1-\eta\right) \frac{\partial b}{\partial Q_{I}}}{A_{I}\left(\frac{b \eta}{A_{I}}+\frac{(1-b) \eta}{A_{D}}+1-\eta\right)^{2}}>0 \\
& \frac{\partial \delta_{R N}}{\partial Q_{I}}=\eta \frac{\left(-1+\eta-\frac{\eta}{A_{I}}\right) \frac{\partial b}{\partial Q_{I}}}{A_{D}\left(\frac{b \eta}{A_{I}}+\frac{(1-b) \eta}{A_{D}}+1-\eta\right)^{2}}<0
\end{aligned}
$$

Substitute (B.2) and (B.3) into (B.1) and rearrange to obtain:

$$
\begin{aligned}
\frac{\partial \widehat{P_{E}}}{\partial Q_{I}}=\left[\left(\left(\frac{\eta}{A_{D} A_{I}}+\frac{1}{A_{I}}-\frac{\eta}{A_{I}}\right)\left(1-A_{I}-\alpha_{I \eta}\right)-\left(\frac{1}{A_{D}}-\frac{\eta}{A_{D}}+\frac{\eta}{A_{I} A_{D}}\right)\left(1-A_{D}\right)\right)\right. \\
\left.+\left(1-\frac{A_{I}}{A_{D}}\right)\left(\frac{\eta}{A_{D} A_{I}}+\frac{1}{A_{I}}-\frac{\eta}{A_{I}}\right) b_{\eta}\right] \frac{\eta}{\left(\frac{b \eta}{A_{I}}+\frac{(1-b) \eta}{A_{D}}+1-\eta\right)^{2}} \frac{\partial b}{\partial Q_{I}} \hat{\eta}>0
\end{aligned}
$$

with conditions $0<A_{I}<A_{D}<1,1-A_{I}-\alpha_{I \eta}>1-A_{D}, b_{\eta} \geq 0, \hat{\eta}>0$, and $\partial b / \partial Q_{I}>0$.

Similarly, we can show that 


$$
\begin{aligned}
\frac{\partial \widehat{P_{E}}}{\partial Q_{D}}=\left[\left(\left(\frac{\eta}{A_{D} A_{I}}+\frac{1}{A_{I}}-\frac{\eta}{A_{I}}\right)\left(1-A_{I}-\alpha_{I \eta}\right)-\left(\frac{1}{A_{D}}-\frac{\eta}{A_{D}}+\frac{\eta}{A_{I} A_{D}}\right)\left(1-A_{D}\right)\right)\right. \\
\left.+\left(1-\frac{A_{I}}{A_{D}}\right)\left(\frac{\eta}{A_{D} A_{I}}+\frac{1}{A_{I}}-\frac{\eta}{A_{I}}\right) b_{\eta}\right] \frac{\partial b}{\left(\frac{b \eta}{A_{I}}+\frac{(1-b) \eta}{A_{D}}+1-\eta\right)^{2}} \frac{\partial b}{\partial Q_{D}} \hat{\eta}<0
\end{aligned}
$$

with conditions $0<A_{I}<A_{D}<1,1-A_{I}-\alpha_{I \eta}>1-A_{D}, b_{\eta} \geq 0, \hat{\eta}>0$, and $\partial b / \partial Q_{D}<0$. Second, totally differentiate $\hat{C}, \widehat{F}, \widehat{R}, \widehat{R_{I}}$, and $\widehat{R_{D}}$ with respect to $Q_{I}$ and $Q_{D}$ :

$$
\begin{aligned}
& \frac{\partial \hat{C}}{\partial Q_{I}}=\frac{\partial \hat{F}}{\partial Q_{I}}=\frac{\partial \hat{R}}{\partial Q_{I}}=\frac{\partial \widehat{R_{I}}}{\partial Q_{I}}=-\left(\gamma_{E}+\gamma_{X} \sigma_{X}\right) \frac{\partial \widehat{P_{E}}}{\partial Q_{I}}<0 \\
& \frac{\partial \widehat{R_{I}}}{\partial Q_{I}}=-\left(\gamma_{E}+\gamma_{X} \sigma_{X}\right) \frac{\partial \widehat{P_{E}}}{\partial Q_{I}}<0 \\
& \frac{\partial \widehat{R_{D}}}{\partial Q_{I}}=-\left(\gamma_{E}+\gamma_{X} \sigma_{X}\right) \frac{\partial \widehat{P_{E}}}{\partial Q_{I}}-b_{\eta} \hat{\eta} \frac{\partial b}{\partial Q_{I}}<0 \\
& \frac{\partial \hat{C}}{\partial Q_{D}}=\frac{\partial \widehat{R}}{\partial Q_{D}}=\frac{\partial \widehat{R_{I}}}{\partial Q_{D}}=-\left(\gamma_{E}+\gamma_{X} \sigma_{X}\right) \frac{\partial \widehat{P_{E}}}{\partial Q_{D}}>0 \\
& \frac{\partial \widehat{R_{I}}}{\partial Q_{D}}=-\left(\gamma_{E}+\gamma_{X} \sigma_{X}\right) \frac{\partial \widehat{P_{E}}}{\partial Q_{D}}>0 \\
& \frac{\partial \widehat{R_{D}}}{\partial Q_{D}}=-\left(\gamma_{E}+\gamma_{X} \sigma_{X}\right) \frac{\partial \widehat{P_{E}}}{\partial Q_{D}}-b_{\eta} \hat{\eta} \frac{\partial b}{\partial Q_{D}}>0
\end{aligned}
$$

To prove the third theorem, we differentiate $\widehat{P_{E}}, \hat{C}, \widehat{F}, \widehat{R}, \widehat{R_{I}}$, and $\widehat{R_{D}}$ with respect to $\alpha_{I \eta}$ :

$$
\begin{gathered}
\frac{\partial \widehat{P_{E}}}{\alpha_{I \eta}}=-\delta_{R I}<0 \\
\frac{\partial \hat{C}}{\partial \alpha_{I \eta}}=\frac{\partial \widehat{F}}{\partial \alpha_{I \eta}}=\frac{\partial \widehat{R}}{\partial \alpha_{I \eta}}=\frac{\partial \widehat{R_{I}}}{\partial \alpha_{I \eta}}=\frac{\partial \widehat{R_{D}}}{\partial \alpha_{I \eta}}=\left(\gamma_{E}+\gamma_{X} \sigma_{X}\right) \delta_{R I}>0
\end{gathered}
$$


Appendix C: Robustness Check Tables and Figures

Table C1: Estimated Determinants of How RPS Requirements Relate to Electricity Prices

\begin{tabular}{|c|c|c|c|c|c|c|}
\hline \multirow{3}{*}{ Independent variables } & \multicolumn{6}{|c|}{ Electricity Price } \\
\hline & \multicolumn{2}{|c|}{$\underline{\text { Residential }}$} & \multicolumn{2}{|c|}{ Commercial } & \multicolumn{2}{|c|}{ Industrial } \\
\hline & (1) & (2) & (3) & (4) & (5) & (6) \\
\hline$a-r p s$ & $\begin{array}{l}-0.01 \\
(0.19)\end{array}$ & & $\begin{array}{c}0.15 \\
(0.20)\end{array}$ & & $\begin{array}{c}0.13 \\
(0.21)\end{array}$ & \\
\hline$r$-rps & $\begin{array}{c}-5.29 \\
(23.5)\end{array}$ & $\begin{array}{l}-5.23 \\
(23.6)\end{array}$ & $\begin{array}{c}20.7 \\
(28.0)\end{array}$ & $\begin{array}{c}20.0 \\
(28.7)\end{array}$ & $\begin{array}{c}41.0 \\
(34.8)\end{array}$ & $\begin{array}{c}40.4 \\
(34.8)\end{array}$ \\
\hline$r$-rps $\times i-r e p$ & $\begin{array}{c}0.74 \\
(2.33)\end{array}$ & $\begin{array}{c}0.72 \\
(2.35)\end{array}$ & $\begin{array}{c}0.19 \\
(2.40)\end{array}$ & $\begin{array}{c}0.34 \\
(2.40)\end{array}$ & $\begin{array}{c}0.30 \\
(2.05)\end{array}$ & $\begin{array}{c}0.44 \\
(2.08)\end{array}$ \\
\hline$r$-rps $\times d$-rep & $\begin{array}{c}-5.94 \\
(2.11)\end{array}$ & $\begin{array}{l}-5.93 \\
(2.11)\end{array}$ & $\begin{array}{l}-4.40 \\
(1.93)\end{array}$ & $\begin{array}{c}-4.49 \\
(1.90)\end{array}$ & $\begin{array}{c}-5.70 \\
(1.50)\end{array}$ & $\begin{array}{c}-5.77 \\
(1.48)\end{array}$ \\
\hline$r$-rps $\times w$-inter & $\begin{array}{c}28.4 \\
(10.3)\end{array}$ & $\begin{array}{c}28.4 \\
(10.4)\end{array}$ & $\begin{array}{c}12.7 \\
(9.94)\end{array}$ & $\begin{array}{c}13.2 \\
(10.1)\end{array}$ & $\begin{array}{c}11.0 \\
(11.1)\end{array}$ & $\begin{array}{c}11.4 \\
(11.0)\end{array}$ \\
\hline Mean dependent variable & 9.48 & 9.48 & 8.19 & 8.19 & 5.88 & 5.88 \\
\hline Observations & 1196 & 1196 & 1196 & 1196 & 1196 & 1196 \\
\hline State fixed effects & Yes & Yes & Yes & Yes & Yes & Yes \\
\hline Time fixed effects & Yes & Yes & Yes & Yes & Yes & Yes \\
\hline Adj R-squared & 0.85 & 0.85 & 0.78 & 0.78 & 0.75 & 0.75 \\
\hline
\end{tabular}

Notes: The dependent variable is average residential electricity price in columns (1) and (2), average commercial electricity price in columns (3) and (4), and average industrial electricity price in columns (5) and (6). Key variables of interests are the interaction of the policy renewable requirement ( $r$-rps) with the state intermittent renewable potential (i-rep), the state dispatchable renewable potential (d-rep), and the state wind intermittency ( $w$ inter). Variable $a$-rps indicates whether the state adopts an RPS. Robust standard errors are clustered at the state level in parentheses. 
Table C2.1: Estimated Determinants of How RPS Requirements Relate to Electricity Price

\begin{tabular}{|c|c|c|c|c|c|c|c|c|}
\hline & (1) & (2) & (3) & (4) & (5) & (6) & (7) & (8) \\
\hline$a-r p s$ & $\begin{array}{c}0.19 \\
(0.18)\end{array}$ & & $\begin{array}{c}0.11 \\
(0.18)\end{array}$ & & $\begin{array}{c}0.11 \\
(0.18)\end{array}$ & & $\begin{array}{c}0.11 \\
(0.18)\end{array}$ & \\
\hline$r$-rps & $\begin{array}{c}24.0 \\
(28.1)\end{array}$ & $\begin{array}{c}22.7 \\
(29.0)\end{array}$ & $\begin{array}{c}25.5 \\
(26.0)\end{array}$ & $\begin{array}{c}24.9 \\
(26.5)\end{array}$ & $\begin{array}{c}25.3 \\
(25.9)\end{array}$ & $\begin{array}{c}24.8 \\
(26.4)\end{array}$ & $\begin{array}{c}23.5 \\
(26.0)\end{array}$ & $\begin{array}{c}23,0 \\
(26.5)\end{array}$ \\
\hline$r$-rps $\times i-r e p$ & $\begin{array}{c}17.6 \\
(10.2)\end{array}$ & $\begin{array}{c}18.6 \\
(10.4)\end{array}$ & $\begin{array}{c}16.6 \\
(9.78)\end{array}$ & $\begin{array}{c}16.9 \\
(9.89)\end{array}$ & $\begin{array}{c}16.7 \\
(9.69)\end{array}$ & $\begin{array}{c}17.0 \\
(9.81)\end{array}$ & $\begin{array}{c}17.4 \\
(9.59)\end{array}$ & $\begin{array}{r}17.8 \\
(9.71)\end{array}$ \\
\hline$r$-rps $\times d$-rep & $\begin{array}{c}-5.73 \\
(1.71)\end{array}$ & $\begin{array}{l}-5.94 \\
(1.66)\end{array}$ & $\begin{array}{l}-5.53 \\
(1.76)\end{array}$ & $\begin{array}{l}-5.59 \\
(1.73)\end{array}$ & $\begin{array}{l}-5.54 \\
(1.76)\end{array}$ & $\begin{array}{l}-5.60 \\
(1.74)\end{array}$ & $\begin{array}{c}-5.44 \\
(1.76)\end{array}$ & $\begin{array}{c}-5.51 \\
(1.73)\end{array}$ \\
\hline$r$-rps $\times w$-inter & $\begin{array}{c}0.52 \\
(2.31)\end{array}$ & $\begin{array}{c}0.82 \\
(2.29)\end{array}$ & $\begin{array}{c}0.27 \\
(2.14)\end{array}$ & $\begin{array}{c}0.38 \\
(2.14)\end{array}$ & $\begin{array}{c}0.27 \\
(2.15)\end{array}$ & $\begin{array}{c}0.38 \\
(2.14)\end{array}$ & $\begin{array}{c}0.028 \\
(2.13)\end{array}$ & $\begin{array}{c}0.14 \\
(2.13)\end{array}$ \\
\hline lhdd & $\begin{array}{l}-1.49 \\
(0.91)\end{array}$ & $\begin{array}{l}-1.48 \\
(0.90)\end{array}$ & $\begin{array}{l}-1.43 \\
(0.80)\end{array}$ & $\begin{array}{l}-1.41 \\
(0.79)\end{array}$ & $\begin{array}{l}-1.42 \\
(0.80)\end{array}$ & $\begin{array}{l}-1.41 \\
(0.79)\end{array}$ & $\begin{array}{c}-1.46 \\
(0.80)\end{array}$ & $\begin{array}{l}-1.45 \\
(0.79)\end{array}$ \\
\hline lcdd & $\begin{array}{c}0.44 \\
(0.19)\end{array}$ & $\begin{array}{c}0.45 \\
(0.20)\end{array}$ & $\begin{array}{c}0.41 \\
(0.18)\end{array}$ & $\begin{array}{c}0.41 \\
(0.18)\end{array}$ & $\begin{array}{c}0.42 \\
(0.18)\end{array}$ & $\begin{array}{c}0.42 \\
(0.18)\end{array}$ & $\begin{array}{c}0.42 \\
(0.18)\end{array}$ & $\begin{array}{c}0.42 \\
(0.18)\end{array}$ \\
\hline lpop & $\begin{array}{c}-0.17 \\
(2.69)\end{array}$ & $\begin{array}{c}-0.23 \\
(2.66)\end{array}$ & $\begin{array}{c}0.69 \\
(2.59)\end{array}$ & $\begin{array}{c}0.75 \\
(2.61)\end{array}$ & $\begin{array}{c}0.67 \\
(2.57)\end{array}$ & $\begin{array}{c}0.73 \\
(2.60)\end{array}$ & $\begin{array}{c}0.63 \\
(2.56)\end{array}$ & $\begin{array}{c}0.69 \\
(2.59)\end{array}$ \\
\hline hlcv & & & $\begin{array}{l}-0.005 \\
(0.00)\end{array}$ & $\begin{array}{l}-0.005 \\
(0.00)\end{array}$ & $\begin{array}{l}-0.005 \\
(0.00)\end{array}$ & $\begin{array}{l}-0.005 \\
(0.00)\end{array}$ & $\begin{array}{c}-0.004 \\
(0.00)\end{array}$ & $\begin{array}{l}-0.004 \\
(0.00)\end{array}$ \\
\hline slcv & & & $\begin{array}{l}-0.001 \\
(0.00)\end{array}$ & $\begin{array}{c}-0.001 \\
(0.00)\end{array}$ & $\begin{array}{l}-0.001 \\
(0.00)\end{array}$ & $\begin{array}{l}-0.001 \\
(0.00)\end{array}$ & $\begin{array}{l}-0.001 \\
(0.00)\end{array}$ & $\begin{array}{r}-0.001 \\
(0.00)\end{array}$ \\
\hline eres & & & $\begin{array}{l}0.007 \\
(0.20)\end{array}$ & $\begin{array}{c}0.02 \\
(0.21)\end{array}$ & $\begin{array}{c}0.01 \\
(0.20)\end{array}$ & $\begin{array}{c}0.018 \\
(0.21)\end{array}$ & $\begin{array}{c}-0.02 \\
(0.20)\end{array}$ & $\begin{array}{c}-0.02 \\
(0.21)\end{array}$ \\
\hline ees & & & $\begin{array}{c}0.23 \\
(0.16)\end{array}$ & $\begin{array}{c}0.24 \\
(0.17)\end{array}$ & $\begin{array}{c}0.23 \\
(0.17)\end{array}$ & $\begin{array}{c}0.24 \\
(0.17)\end{array}$ & $\begin{array}{c}0.21 \\
(0.16)\end{array}$ & $\begin{array}{c}0.22 \\
(0.17)\end{array}$ \\
\hline$c t i$ & & & $\begin{array}{l}-0.008 \\
(0.22)\end{array}$ & $\begin{array}{l}-0.004 \\
(0.22)\end{array}$ & $\begin{array}{c}-0.01 \\
(0.22)\end{array}$ & $\begin{array}{c}-0.004 \\
(0.22)\end{array}$ & $\begin{array}{c}0.01 \\
(0.21)\end{array}$ & $\begin{array}{c}0.02 \\
(0.21)\end{array}$ \\
\hline$s p f$ & & & $\begin{array}{c}0.37 \\
(0.16)\end{array}$ & $\begin{array}{c}0.38 \\
(0.16)\end{array}$ & $\begin{array}{c}0.37 \\
(0.16)\end{array}$ & $\begin{array}{c}0.38 \\
(0.16)\end{array}$ & $\begin{array}{c}0.36 \\
(0.15)\end{array}$ & $\begin{array}{c}0.37 \\
(0.15)\end{array}$ \\
\hline g-ideo & & & $\begin{array}{c}-0.003 \\
(0.01)\end{array}$ & $\begin{array}{c}-0.003 \\
(0.00)\end{array}$ & $\begin{array}{c}-0.003 \\
(0.01)\end{array}$ & $\begin{array}{c}-0.003 \\
(0.01)\end{array}$ & $\begin{array}{c}-0.003 \\
(0.01)\end{array}$ & $\begin{array}{c}-0.003 \\
(0.01)\end{array}$ \\
\hline c-ideo & & & $\begin{array}{c}0.01 \\
(0.00)\end{array}$ & $\begin{array}{c}0.01 \\
(0.01)\end{array}$ & $\begin{array}{c}0.01 \\
(0.01)\end{array}$ & $\begin{array}{c}0.01 \\
(0.01)\end{array}$ & $\begin{array}{c}0.01 \\
(0.01)\end{array}$ & $\begin{array}{c}0.01 \\
(0.01)\end{array}$ \\
\hline $\operatorname{lngp}$ & & & & & $\begin{array}{c}0.09 \\
(0.61)\end{array}$ & $\begin{array}{c}0.08 \\
(0.61)\end{array}$ & $\begin{array}{c}-0.01 \\
(0.58)\end{array}$ & $\begin{array}{c}-0.01 \\
(0.58)\end{array}$ \\
\hline$e-i m p$ & & & & & & & $\begin{array}{c}-0.40 \\
(0.18)\end{array}$ & $\begin{array}{c}-0.40 \\
(0.18)\end{array}$ \\
\hline Observations & 1196 & 1196 & 1196 & 1196 & 1196 & 1196 & 1196 & 1196 \\
\hline State fixed effects & Yes & Yes & Yes & Yes & Yes & Yes & Yes & Yes \\
\hline Year fixed effects & Yes & Yes & Yes & Yes & Yes & Yes & Yes & Yes \\
\hline Adj R-squared & 0.67 & 0.68 & 0.68 & 0.68 & 0.68 & 0.68 & 0.70 & 0.70 \\
\hline
\end{tabular}

Notes: The dependent variable is average electricity price across all sectors. Robust standard errors are clustered at the state level in parentheses. 
Table C2.2: Estimated Determinants of How RPS Requirements Relate to Electricity Price

\begin{tabular}{|c|c|c|c|c|c|c|c|c|}
\hline & (1) & (2) & (3) & (4) & (5) & (6) & (7) & (8) \\
\hline$a-r p s$ & $\begin{array}{c}0.50 \\
(0.33)\end{array}$ & & $\begin{array}{c}0.40 \\
(0.34)\end{array}$ & & $\begin{array}{c}0.40 \\
(0.35)\end{array}$ & & $\begin{array}{c}0.42 \\
(0.35)\end{array}$ & \\
\hline$r$-rps & $\begin{array}{c}26.9 \\
(24.9)\end{array}$ & $\begin{array}{c}26.9 \\
(24.9)\end{array}$ & $\begin{array}{c}26.3 \\
(23.6)\end{array}$ & $\begin{array}{c}26.3 \\
(23.6)\end{array}$ & $\begin{array}{c}26.1 \\
(23.5)\end{array}$ & $\begin{array}{c}26.1 \\
(23.5)\end{array}$ & $\begin{array}{c}25.2 \\
(23.6)\end{array}$ & $\begin{array}{c}25.2 \\
(23.6)\end{array}$ \\
\hline$r$-rps $\times i-r e p$ & $\begin{array}{c}0.91 \\
(2.31)\end{array}$ & $\begin{array}{c}0.91 \\
(2.31)\end{array}$ & $\begin{array}{c}0.74 \\
(2.22)\end{array}$ & $\begin{array}{c}0.74 \\
(2.22)\end{array}$ & $\begin{array}{c}0.74 \\
(2.23)\end{array}$ & $\begin{array}{c}0.74 \\
(2.23)\end{array}$ & $\begin{array}{c}0.52 \\
(2.27)\end{array}$ & $\begin{array}{c}0.52 \\
(2.27)\end{array}$ \\
\hline$r$-rps $\times d$-rep & $\begin{array}{l}-5.60 \\
(1.64)\end{array}$ & $\begin{array}{l}-5.60 \\
(1.64)\end{array}$ & $\begin{array}{l}-5.47 \\
(1.69)\end{array}$ & $\begin{array}{l}-5.47 \\
(1.69)\end{array}$ & $\begin{array}{l}-5.48 \\
(1.69)\end{array}$ & $\begin{array}{l}-5.48 \\
(1.69)\end{array}$ & $\begin{array}{l}-5.45 \\
(1.70)\end{array}$ & $\begin{array}{l}-5.45 \\
(1.70)\end{array}$ \\
\hline$r$-rps $\times w$-inter & $\begin{array}{c}15.0 \\
(9.26)\end{array}$ & $\begin{array}{c}15.0 \\
(9.26)\end{array}$ & $\begin{array}{c}14.9 \\
(9.01)\end{array}$ & $\begin{array}{c}14.9 \\
(9.01)\end{array}$ & $\begin{array}{c}15.0 \\
(8.95)\end{array}$ & $\begin{array}{c}15.0 \\
(8.95)\end{array}$ & $\begin{array}{c}15.6 \\
(8.84)\end{array}$ & $\begin{array}{c}15.6 \\
(8.84)\end{array}$ \\
\hline$A C P$ & $\begin{array}{c}0.32 \\
(0.29)\end{array}$ & $\begin{array}{c}0.32 \\
(0.29)\end{array}$ & $\begin{array}{c}0.31 \\
(0.28)\end{array}$ & $\begin{array}{c}0.31 \\
(0.28)\end{array}$ & $\begin{array}{c}0.31 \\
(0.28)\end{array}$ & $\begin{array}{c}0.31 \\
(0.28)\end{array}$ & $\begin{array}{c}0.27 \\
(0.30)\end{array}$ & $\begin{array}{c}0.27 \\
(0.30)\end{array}$ \\
\hline Multiplier & $\begin{array}{l}-0.50 \\
(0.26)\end{array}$ & $\begin{array}{l}-0.50 \\
(0.26)\end{array}$ & $\begin{array}{l}-0.42 \\
(0.27)\end{array}$ & $\begin{array}{l}-0.42 \\
(0.27)\end{array}$ & $\begin{array}{l}-0.42 \\
(0.28)\end{array}$ & $\begin{array}{l}-0.42 \\
(0.28)\end{array}$ & $\begin{array}{l}-0.41 \\
(0.28)\end{array}$ & $\begin{array}{c}-0.41 \\
(0.28)\end{array}$ \\
\hline Carveout & $\begin{array}{l}-0.42 \\
(0.26)\end{array}$ & $\begin{array}{l}-0.42 \\
(0.26)\end{array}$ & $\begin{array}{l}-0.43 \\
(0.27)\end{array}$ & $\begin{array}{l}-0.43 \\
(0.27)\end{array}$ & $\begin{array}{l}-0.43 \\
(0.27)\end{array}$ & $\begin{array}{l}-0.43 \\
(0.27)\end{array}$ & $\begin{array}{l}-0.42 \\
(0.28)\end{array}$ & $\begin{array}{c}-0.42 \\
(0.28)\end{array}$ \\
\hline Trading & $\begin{array}{c}0.00 \\
(0.00)\end{array}$ & $\begin{array}{c}0.50 \\
(0.33)\end{array}$ & $\begin{array}{c}0.00 \\
(0.00)\end{array}$ & $\begin{array}{c}0.40 \\
(0.34)\end{array}$ & $\begin{array}{c}0.00 \\
(0.00)\end{array}$ & $\begin{array}{c}0.40 \\
(0.35)\end{array}$ & $\begin{array}{c}0.00 \\
(0.00)\end{array}$ & $\begin{array}{c}0.42 \\
(0.35)\end{array}$ \\
\hline lhdd & $\begin{array}{l}-1.41 \\
(0.92)\end{array}$ & $\begin{array}{l}-1.41 \\
(0.92)\end{array}$ & $\begin{array}{l}-1.38 \\
(0.80)\end{array}$ & $\begin{array}{l}-1.38 \\
(0.80)\end{array}$ & $\begin{array}{l}-1.37 \\
(0.80)\end{array}$ & $\begin{array}{l}-1.37 \\
(0.80)\end{array}$ & $\begin{array}{l}-1.40 \\
(0.80)\end{array}$ & $\begin{array}{l}-1.40 \\
(0.80)\end{array}$ \\
\hline lcdd & $\begin{array}{c}0.39 \\
(0.19)\end{array}$ & $\begin{array}{c}0.39 \\
(0.19)\end{array}$ & $\begin{array}{c}0.38 \\
(0.18)\end{array}$ & $\begin{array}{c}0.38 \\
(0.18)\end{array}$ & $\begin{array}{c}0.38 \\
(0.18)\end{array}$ & $\begin{array}{c}0.38 \\
(0.18)\end{array}$ & $\begin{array}{c}0.39 \\
(0.18)\end{array}$ & $\begin{array}{c}0.39 \\
(0.18)\end{array}$ \\
\hline lpop & $\begin{array}{c}1.89 \\
(2.85)\end{array}$ & $\begin{array}{c}1.89 \\
(2.85)\end{array}$ & $\begin{array}{c}2.41 \\
(2.79)\end{array}$ & $\begin{array}{c}2.41 \\
(2.79)\end{array}$ & $\begin{array}{c}2.38 \\
(2.77)\end{array}$ & $\begin{array}{c}2.38 \\
(2.77)\end{array}$ & $\begin{array}{c}2.28 \\
(2.77)\end{array}$ & $\begin{array}{c}2.28 \\
(2.77)\end{array}$ \\
\hline hlcv & & & $\begin{array}{l}-0.004 \\
(0.00)\end{array}$ & $\begin{array}{l}-0.004 \\
(0.002)\end{array}$ & $\begin{array}{l}-0.004 \\
(0.00)\end{array}$ & $\begin{array}{l}-0.004 \\
(0.00)\end{array}$ & $\begin{array}{l}-0.004 \\
(0.00)\end{array}$ & $\begin{array}{l}-0.004 \\
(0.00)\end{array}$ \\
\hline slcv & & & $\begin{array}{l}-0.001 \\
(0.00)\end{array}$ & $\begin{array}{l}-0.001 \\
(0.00)\end{array}$ & $\begin{array}{l}-0.001 \\
(0.00)\end{array}$ & $\begin{array}{l}-0.001 \\
(0.00)\end{array}$ & $\begin{array}{l}-0.001 \\
(0.00)\end{array}$ & $\begin{array}{l}-0.001 \\
(0.00)\end{array}$ \\
\hline eres & & & $\begin{array}{l}0.043 \\
(0.15)\end{array}$ & $\begin{array}{c}0.04 \\
(0.15)\end{array}$ & $\begin{array}{l}0.043 \\
(0.15)\end{array}$ & $\begin{array}{c}0.04 \\
(0.15)\end{array}$ & $\begin{array}{c}0.03 \\
(0.15)\end{array}$ & $\begin{array}{l}0.027 \\
(0.15)\end{array}$ \\
\hline ees & & & $\begin{array}{c}0.26 \\
(0.16)\end{array}$ & $\begin{array}{c}0.26 \\
(0.16)\end{array}$ & $\begin{array}{c}0.26 \\
(0.16)\end{array}$ & $\begin{array}{c}0.26 \\
(0.16)\end{array}$ & $\begin{array}{c}0.24 \\
(0.16)\end{array}$ & $\begin{array}{c}0.24 \\
(0.16)\end{array}$ \\
\hline$c t i$ & & & $\begin{array}{l}-0.02 \\
(0.21)\end{array}$ & $\begin{array}{l}-0.02 \\
\left(0.2^{\prime}\right)\end{array}$ & $\begin{array}{l}-0.02 \\
(0.21)\end{array}$ & $\begin{array}{l}-0.015 \\
(0.21)\end{array}$ & $\begin{array}{l}0.003 \\
(0.20)\end{array}$ & $\begin{array}{l}0.003 \\
(0.20)\end{array}$ \\
\hline spf & & & $\begin{array}{c}0.27 \\
(0.15)\end{array}$ & $\begin{array}{c}0.27 \\
(0.15)\end{array}$ & $\begin{array}{c}0.27 \\
(0.15)\end{array}$ & $\begin{array}{c}0.27 \\
(0.15)\end{array}$ & $\begin{array}{c}0.27 \\
(0.15)\end{array}$ & $\begin{array}{c}0.27 \\
(0.15)\end{array}$ \\
\hline g-ideo & & & $\begin{array}{l}-0.004 \\
(0.00)\end{array}$ & $\begin{array}{l}-0.004 \\
(0.00)\end{array}$ & $\begin{array}{l}-0.004 \\
(0.00)\end{array}$ & $\begin{array}{l}-0.004 \\
(0.00)\end{array}$ & $\begin{array}{l}-0.004 \\
(0.00)\end{array}$ & $\begin{array}{l}-0.004 \\
(0.00)\end{array}$ \\
\hline c-ideo & & & $\begin{array}{c}0.01 \\
(0.00\end{array}$ & $\begin{array}{c}0.01 \\
(0.01)\end{array}$ & $\begin{array}{c}0.01 \\
(0.01)\end{array}$ & $\begin{array}{c}0.01 \\
(0.00)\end{array}$ & $\begin{array}{c}0.01 \\
(0.01)\end{array}$ & $\begin{array}{c}0.01 \\
(0.01)\end{array}$ \\
\hline $\operatorname{lngp}$ & & & & & $\begin{array}{c}0.17 \\
(0.61)\end{array}$ & $\begin{array}{c}0.17 \\
(0.61)\end{array}$ & $\begin{array}{c}0.09 \\
(0.59)\end{array}$ & $\begin{array}{c}0.09 \\
(0.60)\end{array}$ \\
\hline e-imp & & & & & & & $\begin{array}{l}-0.33 \\
(0.19)\end{array}$ & $\begin{array}{c}-0.33 \\
(0.19)\end{array}$ \\
\hline Observations & 1196 & 1196 & 1196 & 1196 & 1196 & 1196 & 1196 & 1196 \\
\hline State fixed effects & Yes & Yes & Yes & Yes & Yes & Yes & Yes & Yes \\
\hline Year fixed effects & Yes & Yes & Yes & Yes & Yes & Yes & Yes & Yes \\
\hline Adj R-squared & 0.84 & 0.84 & 0.84 & 0.84 & 0.84 & 0.84 & 0.84 & 0.84 \\
\hline
\end{tabular}

Notes: The dependent variable is average electricity price across all sectors. Robust standard errors are clustered at the state level in parentheses. 
Table C3.1: Estimated Determinants of How RPS Requirements Relate to $\mathrm{CO}_{2}$ Emissions from all Sectors

\begin{tabular}{|c|c|c|c|c|c|c|c|c|}
\hline & (1) & (2) & (3) & (4) & (5) & (6) & (7) & (8) \\
\hline$a-r p s$ & $\begin{array}{l}-0.02 \\
(0.02)\end{array}$ & & $\begin{array}{l}-0.01 \\
(0.02)\end{array}$ & & $\begin{array}{l}-0.01 \\
(0.02)\end{array}$ & & $\begin{array}{l}-0.01 \\
(0.01)\end{array}$ & \\
\hline$r$-rps & $\begin{array}{l}1.75 \\
(3.02)\end{array}$ & $\begin{array}{l}1.86 \\
(2.90)\end{array}$ & $\begin{array}{l}2.71 \\
(3.01)\end{array}$ & $\begin{array}{c}2.75 \\
(2.96)\end{array}$ & $\begin{array}{l}2.81 \\
(3.01)\end{array}$ & $\begin{array}{c}2.85 \\
(2.95)\end{array}$ & $\begin{array}{c}2.38 \\
(2.86)\end{array}$ & $\begin{array}{c}2.42 \\
(2.80)\end{array}$ \\
\hline$r$-rps $\times i$-rep & $\begin{array}{l}-0.23 \\
(0.17)\end{array}$ & $\begin{array}{l}-0.26 \\
(0.17)\end{array}$ & $\begin{array}{l}-0.20 \\
(0.19)\end{array}$ & $\begin{array}{l}-0.20 \\
(0.19)\end{array}$ & $\begin{array}{l}-0.20 \\
(0.18)\end{array}$ & $\begin{array}{l}-0.21 \\
(0.18)\end{array}$ & $\begin{array}{l}-0.26 \\
-0.15\end{array}$ & $\begin{array}{l}-0.27 \\
-0.15\end{array}$ \\
\hline$r$-rps $\times d$-rep & $\begin{array}{c}0.47 \\
(0.17)\end{array}$ & $\begin{array}{c}0.49 \\
(0.17)\end{array}$ & $\begin{array}{c}0.40 \\
(0.15)\end{array}$ & $\begin{array}{c}0.41 \\
(0.15)\end{array}$ & $\begin{array}{c}0.41 \\
(0.15)\end{array}$ & $\begin{array}{c}0.41 \\
(0.15)\end{array}$ & $\begin{array}{c}0.43 \\
(0.14)\end{array}$ & $\begin{array}{c}0.44 \\
(0.14)\end{array}$ \\
\hline$r$-rps $\times w$-inter & $\begin{array}{l}-2.30 \\
(1.01)\end{array}$ & $\begin{array}{l}-2.38 \\
(0.96)\end{array}$ & $\begin{array}{l}-2.37 \\
(1.00)\end{array}$ & $\begin{array}{l}-2.40 \\
(0.97)\end{array}$ & $\begin{array}{l}-2.42 \\
(1.00)\end{array}$ & $\begin{array}{l}-2.45 \\
(0.98)\end{array}$ & $\begin{array}{l}-2.25 \\
(0.97)\end{array}$ & $\begin{array}{l}-2.27 \\
(0.95)\end{array}$ \\
\hline lhdd & $\begin{array}{c}0.27 \\
(0.07)\end{array}$ & $\begin{array}{c}0.27 \\
(0.07)\end{array}$ & $\begin{array}{c}0.27 \\
(0.07)\end{array}$ & $\begin{array}{c}0.27 \\
(0.07)\end{array}$ & $\begin{array}{c}0.27 \\
(0.07)\end{array}$ & $\begin{array}{c}0.27 \\
(0.07)\end{array}$ & $\begin{array}{c}0.26 \\
(0.06)\end{array}$ & $\begin{array}{c}0.26 \\
(0.06)\end{array}$ \\
\hline lcdd & $\begin{array}{l}0.007 \\
(0.02)\end{array}$ & $\begin{array}{l}0.007 \\
(0.02)\end{array}$ & $\begin{array}{l}0.004 \\
(0.02)\end{array}$ & $\begin{array}{l}0.004 \\
(0.02)\end{array}$ & $\begin{array}{l}0.002 \\
(0.02)\end{array}$ & $\begin{array}{l}0.002 \\
(0.02)\end{array}$ & $\begin{array}{l}0.003 \\
(0.02)\end{array}$ & $\begin{array}{l}0.003 \\
(0.02)\end{array}$ \\
\hline lpop & $\begin{array}{l}-1.19 \\
(0.25)\end{array}$ & $\begin{array}{l}-1.19 \\
(0.25)\end{array}$ & $\begin{array}{l}-1.26 \\
(0.26)\end{array}$ & $\begin{array}{l}-1.27 \\
(0.26)\end{array}$ & $\begin{array}{l}-1.25 \\
(0.26)\end{array}$ & $\begin{array}{l}-1.25 \\
(0.26)\end{array}$ & $\begin{array}{l}-1.26 \\
(0.24)\end{array}$ & $\begin{array}{l}-1.26 \\
(0.24)\end{array}$ \\
\hline hlcv & & & $\begin{array}{c}-0.0003 \\
(0.00)\end{array}$ & $\begin{array}{c}-0.0003 \\
(0.00)\end{array}$ & $\begin{array}{c}-0.0003 \\
(0.00)\end{array}$ & $\begin{array}{c}-0.0003 \\
(0.00)\end{array}$ & $\begin{array}{c}-0.0002 \\
(0.00)\end{array}$ & $\begin{array}{c}-0.0002 \\
(0.00)\end{array}$ \\
\hline slcv & & & $\begin{array}{c}-0.0001 \\
(0.00)\end{array}$ & $\begin{array}{c}-0.0002 \\
(0.00)\end{array}$ & $\begin{array}{c}-0.0001 \\
(0.00)\end{array}$ & $\begin{array}{c}-0.0002 \\
(0.00)\end{array}$ & $\begin{array}{c}-0.0001 \\
(0.00)\end{array}$ & $\begin{array}{c}-0.0002 \\
(0.00)\end{array}$ \\
\hline eres & & & $\begin{array}{l}-0.04 \\
(0.02)\end{array}$ & $\begin{array}{l}-0.04 \\
(0.02)\end{array}$ & $\begin{array}{l}-0.04 \\
(0.02)\end{array}$ & $\begin{array}{l}-0.04 \\
(0.02)\end{array}$ & $\begin{array}{l}-0.05 \\
(0.02)\end{array}$ & $\begin{array}{l}-0.05 \\
(0.02)\end{array}$ \\
\hline ees & & & $\begin{array}{l}-0.02 \\
(0.02)\end{array}$ & $\begin{array}{l}-0.02 \\
(0.02)\end{array}$ & $\begin{array}{l}-0.02 \\
(0.02)\end{array}$ & $\begin{array}{l}-0.02 \\
(0.02)\end{array}$ & $\begin{array}{l}-0.02 \\
(0.02)\end{array}$ & $\begin{array}{l}-0.02 \\
(0.02)\end{array}$ \\
\hline$c t i$ & & & $\begin{array}{l}0.006 \\
(0.02)\end{array}$ & $\begin{array}{l}0.006 \\
(0.02)\end{array}$ & $\begin{array}{l}0.006 \\
(0.02)\end{array}$ & $\begin{array}{l}0.006 \\
(0.02)\end{array}$ & $\begin{array}{c}0.01 \\
(0.02)\end{array}$ & $\begin{array}{c}0.01 \\
(0.02)\end{array}$ \\
\hline $\operatorname{spf}$ & & & $\begin{array}{r}-0.007 \\
(0.02)\end{array}$ & $\begin{array}{l}-0.008 \\
(0.02)\end{array}$ & $\begin{array}{l}-0.008 \\
(0.02)\end{array}$ & $\begin{array}{l}-0.009 \\
(0.02)\end{array}$ & $\begin{array}{l}-0.01 \\
(0.02)\end{array}$ & $\begin{array}{l}-0.01 \\
(0.02)\end{array}$ \\
\hline g-ideo & & & $\begin{array}{l}0.001 \\
(0.00)\end{array}$ & $\begin{array}{l}0.001 \\
(0.00)\end{array}$ & $\begin{array}{l}0.001 \\
(0.00)\end{array}$ & $\begin{array}{l}0.001 \\
(0.00)\end{array}$ & $\begin{array}{l}0.001 \\
(0.00)\end{array}$ & $\begin{array}{l}0.001 \\
(0.00)\end{array}$ \\
\hline c-ideo & & & $\begin{array}{c}-0.0003 \\
(0.00)\end{array}$ & $\begin{array}{c}-0.0003 \\
(0.00)\end{array}$ & $\begin{array}{c}-0.0003 \\
(0.00)\end{array}$ & $\begin{array}{c}-0.0003 \\
(0.00)\end{array}$ & $\begin{array}{l}-0.001 \\
(0.00)\end{array}$ & $\begin{array}{l}-0.001 \\
(0.00)\end{array}$ \\
\hline $\operatorname{lngp}$ & & & & & $\begin{array}{l}-0.05 \\
(0.06)\end{array}$ & $\begin{array}{l}-0.05 \\
(0.06)\end{array}$ & $\begin{array}{l}-0.07 \\
(0.06)\end{array}$ & $\begin{array}{l}-0.07 \\
(0.06)\end{array}$ \\
\hline$e$-imp & & & & & & & $\begin{array}{l}-0.10 \\
(0.06)\end{array}$ & $\begin{array}{l}-0.10 \\
(0.06)\end{array}$ \\
\hline Observations & 1196 & 1196 & 1196 & 1196 & 1196 & 1196 & 1196 & 1196 \\
\hline State fixed effects & Yes & Yes & Yes & Yes & Yes & Yes & Yes & Yes \\
\hline Year fixed effects & Yes & Yes & Yes & Yes & Yes & Yes & Yes & Yes \\
\hline Adj R-squared & 0.67 & 0.68 & 0.68 & 0.68 & 0.68 & 0.68 & 0.70 & 0.70 \\
\hline
\end{tabular}

Notes: The dependent variable is logged total carbon dioxide emissions per capita. Robust standard errors are clustered at the state level in parentheses. 
Table C3.2: Estimated Determinants of How RPS Requirements Relate to $\mathrm{CO}_{2}$ Emissions from all Sectors

\begin{tabular}{|c|c|c|c|c|c|c|c|c|}
\hline & (1) & (2) & (3) & (4) & (5) & (6) & (7) & (8) \\
\hline$a-r p s$ & $\begin{array}{c}0.02 \\
(0.03)\end{array}$ & & $\begin{array}{c}0.01 \\
(0.03)\end{array}$ & & $\begin{array}{c}0.01 \\
(0.03)\end{array}$ & & $\begin{array}{c}0.01 \\
(0.03)\end{array}$ & \\
\hline$r$-rps & $\begin{array}{l}2.49 \\
(2.87)\end{array}$ & $\begin{array}{c}2.49 \\
(2.87)\end{array}$ & $\begin{array}{c}3.00 \\
(3.00)\end{array}$ & $\begin{array}{c}3.00 \\
(3.00)\end{array}$ & $\begin{array}{c}3.07 \\
(2.96)\end{array}$ & $\begin{array}{c}3.07 \\
(2.96)\end{array}$ & $\begin{array}{c}2.80 \\
(2.78)\end{array}$ & $\begin{array}{c}2.80 \\
(2.78)\end{array}$ \\
\hline$r$-rps $\times i$-rep & $\begin{array}{l}-0.19 \\
(0.17)\end{array}$ & $\begin{array}{l}-0.19 \\
(0.17)\end{array}$ & $\begin{array}{l}-0.16 \\
(0.18)\end{array}$ & $\begin{array}{l}-0.16 \\
(0.18)\end{array}$ & $\begin{array}{l}-0.16 \\
(0.18)\end{array}$ & $\begin{array}{l}-0.16 \\
(0.18)\end{array}$ & $\begin{array}{l}-0.22 \\
(0.15)\end{array}$ & $\begin{array}{l}-0.22 \\
(0.15)\end{array}$ \\
\hline$r$-rps $\times d$-rep & $\begin{array}{c}0.40 \\
(0.15)\end{array}$ & $\begin{array}{c}0.40 \\
(0.15)\end{array}$ & $\begin{array}{c}0.36 \\
(0.15)\end{array}$ & $\begin{array}{c}0.36 \\
(0.15)\end{array}$ & $\begin{array}{c}0.37 \\
(0.15)\end{array}$ & $\begin{array}{c}0.37 \\
(0.15)\end{array}$ & $\begin{array}{c}0.38 \\
(0.14)\end{array}$ & $\begin{array}{c}0.38 \\
(0.14)\end{array}$ \\
\hline$r$-rps $\times w$-inter & $\begin{array}{l}-2.33 \\
(0.93)\end{array}$ & $\begin{array}{l}-2.33 \\
(0.93)\end{array}$ & $\begin{array}{l}-2.38 \\
(0.97)\end{array}$ & $\begin{array}{l}-2.38 \\
(0.97)\end{array}$ & $\begin{array}{l}-2.42 \\
(0.97)\end{array}$ & $\begin{array}{l}-2.42 \\
(0.97)\end{array}$ & $\begin{array}{l}-2.24 \\
(0.93)\end{array}$ & $\begin{array}{l}-2.24 \\
(0.93)\end{array}$ \\
\hline$A C P$ & $\begin{array}{l}-0.02 \\
(0.03)\end{array}$ & $\begin{array}{l}-0.02 \\
(0.03)\end{array}$ & $\begin{array}{l}-0.01 \\
(0.03)\end{array}$ & $\begin{array}{l}-0.01 \\
(0.03)\end{array}$ & $\begin{array}{l}-0.01 \\
(0.03)\end{array}$ & $\begin{array}{l}-0.01 \\
(0.03)\end{array}$ & $\begin{array}{l}-0.02 \\
(0.03)\end{array}$ & $\begin{array}{l}-0.02 \\
(0.03)\end{array}$ \\
\hline Multiplier & $\begin{array}{l}-0.004 \\
(0.03)\end{array}$ & $\begin{array}{l}-0.004 \\
(0.03)\end{array}$ & $\begin{array}{l}-0.002 \\
(0.03)\end{array}$ & $\begin{array}{l}-0.002 \\
(0.03)\end{array}$ & $\begin{array}{c}-0.0003 \\
(0.03)\end{array}$ & $\begin{array}{c}-0.0003 \\
(0.03)\end{array}$ & $\begin{array}{l}0.004 \\
(0.03)\end{array}$ & $\begin{array}{l}0.004 \\
(0.03)\end{array}$ \\
\hline Carveout & $\begin{array}{l}-0.04 \\
(0.03)\end{array}$ & $\begin{array}{l}-0.04 \\
(0.03)\end{array}$ & $\begin{array}{l}-0.03 \\
(0.03)\end{array}$ & $\begin{array}{l}-0.03 \\
(0.03)\end{array}$ & $\begin{array}{l}-0.03 \\
(0.03)\end{array}$ & $\begin{array}{l}-0.03 \\
(0.03)\end{array}$ & $\begin{array}{l}-0.03 \\
(0.02)\end{array}$ & $\begin{array}{l}-0.03 \\
(0.02)\end{array}$ \\
\hline Trading & $\begin{array}{c}0.00 \\
(0.00)\end{array}$ & $\begin{array}{c}0.02 \\
(0.03)\end{array}$ & $\begin{array}{c}0.00 \\
(0.00)\end{array}$ & $\begin{array}{c}0.01 \\
(0.03)\end{array}$ & $\begin{array}{c}0.00 \\
(0.00)\end{array}$ & $\begin{array}{c}0.01 \\
(0.03)\end{array}$ & $\begin{array}{c}0.00 \\
(0.00)\end{array}$ & $\begin{array}{c}0.01 \\
(0.03)\end{array}$ \\
\hline Lhdd & $\begin{array}{c}0.28 \\
(0.07)\end{array}$ & $\begin{array}{c}0.28 \\
(0.07)\end{array}$ & $\begin{array}{c}0.28 \\
(0.07)\end{array}$ & $\begin{array}{c}0.28 \\
(0.07)\end{array}$ & $\begin{array}{c}0.27 \\
(0.07)\end{array}$ & $\begin{array}{c}0.27 \\
(0.07)\end{array}$ & $\begin{array}{c}0.27 \\
(0.06)\end{array}$ & $\begin{array}{c}0.27 \\
(0.06)\end{array}$ \\
\hline lcdd & $\begin{array}{c}0.01 \\
(0.02)\end{array}$ & $\begin{array}{c}0.01 \\
(0.02)\end{array}$ & $\begin{array}{l}0.004 \\
(0.02)\end{array}$ & $\begin{array}{l}0.004 \\
(0.02)\end{array}$ & $\begin{array}{l}0.003 \\
(0.02)\end{array}$ & $\begin{array}{l}0.003 \\
(0.02)\end{array}$ & $\begin{array}{l}0.005 \\
(0.02)\end{array}$ & $\begin{array}{l}0.005 \\
(0.02)\end{array}$ \\
\hline lpop & $\begin{array}{l}-1.18 \\
(0.25)\end{array}$ & $\begin{array}{l}-1.18 \\
(0.25)\end{array}$ & $\begin{array}{l}-1.25 \\
(0.26)\end{array}$ & $\begin{array}{l}-1.25 \\
(0.26)\end{array}$ & $\begin{array}{l}-1.24 \\
(0.26)\end{array}$ & $\begin{array}{l}-1.24 \\
(0.26)\end{array}$ & $\begin{array}{l}-1.27 \\
(0.23)\end{array}$ & $\begin{array}{l}-1.27 \\
(0.23)\end{array}$ \\
\hline hlcv & & & $\begin{array}{c}-0.0002 \\
(0.00)\end{array}$ & $\begin{array}{c}-0.0002 \\
(0.00)\end{array}$ & $\begin{array}{c}-0.0002 \\
(0.00)\end{array}$ & $\begin{array}{c}-0.0002 \\
(0.00)\end{array}$ & $\begin{array}{c}-0.0002 \\
(0.00)\end{array}$ & $\begin{array}{c}-0.0002 \\
(0.00)\end{array}$ \\
\hline slcv & & & $\begin{array}{c}-0.0002 \\
(0.00)\end{array}$ & $\begin{array}{c}-0.0002 \\
(0.00)\end{array}$ & $\begin{array}{c}-0.0002 \\
(0.00)\end{array}$ & $\begin{array}{c}-0.0002 \\
(0.00)\end{array}$ & $\begin{array}{c}-0.0002 \\
(0.00)\end{array}$ & $\begin{array}{c}-0.0002 \\
(0.00)\end{array}$ \\
\hline eres & & & $\begin{array}{l}-0.03 \\
(0.02)\end{array}$ & $\begin{array}{l}-0.03 \\
(0.02)\end{array}$ & $\begin{array}{l}-0.03 \\
(0.02)\end{array}$ & $\begin{array}{l}-0.03 \\
(0.02)\end{array}$ & $\begin{array}{l}-0.04 \\
(0.02)\end{array}$ & $\begin{array}{l}-0.04 \\
(0.02)\end{array}$ \\
\hline ees & & & $\begin{array}{l}-0.02 \\
(0.02)\end{array}$ & $\begin{array}{l}-0.02 \\
(0.02)\end{array}$ & $\begin{array}{l}-0.02 \\
(0.02)\end{array}$ & $\begin{array}{l}-0.02 \\
(0.02)\end{array}$ & $\begin{array}{l}-0.02 \\
(0.02)\end{array}$ & $\begin{array}{l}-0.02 \\
(0.02)\end{array}$ \\
\hline$c t i$ & & & $\begin{array}{l}0.005 \\
(0.02)\end{array}$ & $\begin{array}{l}0.005 \\
(0.02)\end{array}$ & $\begin{array}{l}0.004 \\
(0.02)\end{array}$ & $\begin{array}{c}0.004 \\
(0.02)\end{array}$ & $\begin{array}{c}0.01 \\
(0.02)\end{array}$ & $\begin{array}{c}0.01 \\
(0.02)\end{array}$ \\
\hline spf & & & $\begin{array}{l}-0.01 \\
(0.02)\end{array}$ & $\begin{array}{l}-0.01 \\
(0.02)\end{array}$ & $\begin{array}{l}-0.01 \\
(0.02)\end{array}$ & $\begin{array}{l}-0.01 \\
(0.02)\end{array}$ & $\begin{array}{l}-0.01 \\
(0.02)\end{array}$ & $\begin{array}{l}-0.01 \\
(0.02)\end{array}$ \\
\hline g-ideo & & & $\begin{array}{l}0.001 \\
(0.00)\end{array}$ & $\begin{array}{l}0.001 \\
(0.00)\end{array}$ & $\begin{array}{l}0.001 \\
(0.00)\end{array}$ & $\begin{array}{l}0.001 \\
(0.00)\end{array}$ & $\begin{array}{l}0.00^{\prime} \\
(0.00)\end{array}$ & $\begin{array}{l}0.001 \\
(0.00)\end{array}$ \\
\hline c-ideo & & & $\begin{array}{c}-0.0002 \\
(0.00)\end{array}$ & $\begin{array}{c}-0.0002 \\
(0.00)\end{array}$ & $\begin{array}{c}-0.0002 \\
(0.00)\end{array}$ & $\begin{array}{c}-0.0002 \\
(0.00)\end{array}$ & $\begin{array}{l}-0.001 \\
(0.00)\end{array}$ & $\begin{array}{l}-0.001 \\
(0.00)\end{array}$ \\
\hline $\operatorname{lngp}$ & & & & & $\begin{array}{l}-0.05 \\
(0.06)\end{array}$ & $\begin{array}{l}-0.05 \\
(0.06)\end{array}$ & $\begin{array}{l}-0.07 \\
(0.06)\end{array}$ & $\begin{array}{l}-0.07 \\
(0.06)\end{array}$ \\
\hline$e$-imp & & & & & & & $\begin{array}{l}-0.10 \\
(0.06)\end{array}$ & $\begin{array}{l}-0.10 \\
(0.06)\end{array}$ \\
\hline Observations & 1196 & 1196 & 1196 & 1196 & 1196 & 1196 & 1196 & 1196 \\
\hline State fixed effects & Yes & Yes & Yes & Yes & Yes & Yes & Yes & Yes \\
\hline Year fixed effects & Yes & Yes & Yes & Yes & Yes & Yes & Yes & Yes \\
\hline Adj R-squared & 0.67 & 0.68 & 0.68 & 0.68 & 0.68 & 0.68 & 0.70 & 0.70 \\
\hline
\end{tabular}

Notes: The dependent variable is logged total carbon dioxide emissions per capita. Robust standard errors are clustered at the state level in parentheses. 
Table C4.1: Estimated Determinants of How RPS Requirements Relate to $\mathrm{CO}_{2} \mathrm{Emissions}$ from the Electricity Sector

\begin{tabular}{|c|c|c|c|c|c|c|c|c|}
\hline & (1) & (2) & (3) & (4) & $\overline{(5}$ & (6) & (7) & (8) \\
\hline$a-r p s$ & $\begin{array}{c}0.01 \\
(0.03)\end{array}$ & & $\begin{array}{c}0.01 \\
(0.03)\end{array}$ & & $\begin{array}{c}0.01 \\
(0.03)\end{array}$ & & $\begin{array}{c}0.01 \\
(0.03)\end{array}$ & \\
\hline$r$-rps & $\begin{array}{c}10.5 \\
(8.54)\end{array}$ & $\begin{array}{c}10.4 \\
(8.52)\end{array}$ & $\begin{array}{c}11.4 \\
(8.54)\end{array}$ & $\begin{array}{c}11.3 \\
(8.52)\end{array}$ & $\begin{array}{c}11.2 \\
(8.84)\end{array}$ & $\begin{array}{c}11.2 \\
(8.81)\end{array}$ & $\begin{array}{c}9.62 \\
(7.67)\end{array}$ & $\begin{array}{c}9.58 \\
(7.63)\end{array}$ \\
\hline$r$-rps $\times i$-rep & $\begin{array}{l}-0.30 \\
(0.65)\end{array}$ & $\begin{array}{l}-0.29 \\
(0.64)\end{array}$ & $\begin{array}{l}-0.23 \\
(0.63)\end{array}$ & $\begin{array}{l}-0.22 \\
(0.63)\end{array}$ & $\begin{array}{l}-0.23 \\
(0.64)\end{array}$ & $\begin{array}{l}-0.22 \\
(0.63)\end{array}$ & $\begin{array}{l}-0.46 \\
(0.58)\end{array}$ & $\begin{array}{l}-0.45 \\
(0.57)\end{array}$ \\
\hline$r$-rps $\times d$-rep & $\begin{array}{l}1.06 \\
(0.71)\end{array}$ & $\begin{array}{l}1.05 \\
(0.71)\end{array}$ & $\begin{array}{c}1.02 \\
(0.69)\end{array}$ & $\begin{array}{c}1.01 \\
(0.68)\end{array}$ & $\begin{array}{c}1.01 \\
(0.68)\end{array}$ & $\begin{array}{c}1.01 \\
(0.68)\end{array}$ & $\begin{array}{l}1.17 \\
-0.6\end{array}$ & $\begin{array}{l}1.17 \\
-0.6\end{array}$ \\
\hline$r$-rps $\times w$-inter & $\begin{array}{l}-7.60 \\
(2.90)\end{array}$ & $\begin{array}{l}-7.56 \\
(2.88)\end{array}$ & $\begin{array}{l}-7.86 \\
(2.83)\end{array}$ & $\begin{array}{l}-7.83 \\
(2.79)\end{array}$ & $\begin{array}{l}-7.78 \\
(2.95)\end{array}$ & $\begin{array}{l}-7.75 \\
(2.92)\end{array}$ & $\begin{array}{l}-7.45 \\
(2.58)\end{array}$ & $\begin{array}{l}-7.42 \\
(2.55)\end{array}$ \\
\hline lhdd & $\begin{array}{c}0.06 \\
(0.17)\end{array}$ & $\begin{array}{c}0.06 \\
(0.17)\end{array}$ & $\begin{array}{c}0.09 \\
(0.17)\end{array}$ & $\begin{array}{c}0.09 \\
(0.17)\end{array}$ & $\begin{array}{c}0.09 \\
(0.17)\end{array}$ & $\begin{array}{c}0.09 \\
(0.16)\end{array}$ & $\begin{array}{c}0.02 \\
(0.16)\end{array}$ & $\begin{array}{c}0.02 \\
(0.16)\end{array}$ \\
\hline lcdd & $\begin{array}{l}-0.007 \\
(0.06)\end{array}$ & $\begin{array}{l}-0.006 \\
(0.06)\end{array}$ & $\begin{array}{l}-0.001 \\
(0.06)\end{array}$ & $\begin{array}{l}0.0001 \\
(0.06)\end{array}$ & $\begin{array}{l}0.002 \\
(0.07)\end{array}$ & $\begin{array}{l}0.003 \\
(0.07)\end{array}$ & $\begin{array}{l}-0.001 \\
(0.07)\end{array}$ & $\begin{array}{l}-0.001 \\
(0.06)\end{array}$ \\
\hline lpop & $\begin{array}{l}-1.54 \\
(0.64)\end{array}$ & $\begin{array}{l}-1.54 \\
(0.64)\end{array}$ & $\begin{array}{l}-1.69 \\
(0.60)\end{array}$ & $\begin{array}{l}-1.68 \\
(0.61)\end{array}$ & $\begin{array}{l}-1.71 \\
(0.61)\end{array}$ & $\begin{array}{l}-1.71 \\
(0.61)\end{array}$ & $\begin{array}{l}-1.70 \\
(0.50)\end{array}$ & $\begin{array}{l}-1.70 \\
(0.50)\end{array}$ \\
\hline hlcv & & & $\begin{array}{c}0.00001 \\
(0.00)\end{array}$ & $\begin{array}{c}0.00002 \\
(0.00)\end{array}$ & $\begin{array}{c}-0.0002 \\
(0.00)\end{array}$ & $\begin{array}{c}-0.00001 \\
(0.00)\end{array}$ & $\begin{array}{c}0.0002 \\
(0.00)\end{array}$ & $\begin{array}{c}0.0002 \\
(0.00)\end{array}$ \\
\hline slcv & & & $\begin{array}{c}0.00003 \\
(0.00)\end{array}$ & $\begin{array}{c}0.00005 \\
(0.00)\end{array}$ & $\begin{array}{c}0.00002 \\
(0.00)\end{array}$ & $\begin{array}{c}0.00004 \\
(0.00)\end{array}$ & $\begin{array}{c}0.00003 \\
(0.00)\end{array}$ & $\begin{array}{c}0.00005 \\
(0.00)\end{array}$ \\
\hline eres & & & $\begin{array}{l}-0.04 \\
(0.05)\end{array}$ & $\begin{array}{l}-0.04 \\
(0.05)\end{array}$ & $\begin{array}{l}-0.04 \\
(0.05)\end{array}$ & $\begin{array}{l}-0.04 \\
(0.05)\end{array}$ & $\begin{array}{l}-0.06 \\
(0.04)\end{array}$ & $\begin{array}{l}-0.06 \\
(0.04)\end{array}$ \\
\hline ees & & & $\begin{array}{l}-0.06 \\
(0.06)\end{array}$ & $\begin{array}{l}-0.06 \\
(0.06)\end{array}$ & $\begin{array}{l}-0.06 \\
(0.06)\end{array}$ & $\begin{array}{l}-0.06 \\
(0.06)\end{array}$ & $\begin{array}{l}-0.08 \\
(0.05)\end{array}$ & $\begin{array}{l}-0.08 \\
(0.05)\end{array}$ \\
\hline$c t i$ & & & $\begin{array}{c}0.03 \\
(0.05)\end{array}$ & $\begin{array}{c}0.03 \\
(0.05)\end{array}$ & $\begin{array}{c}0.03 \\
(0.05)\end{array}$ & $\begin{array}{c}0.03 \\
(0.05)\end{array}$ & $\begin{array}{c}0.05 \\
(0.05)\end{array}$ & $\begin{array}{c}0.05 \\
(0.05)\end{array}$ \\
\hline$s p f$ & & & $\begin{array}{c}0.01 \\
(0.04)\end{array}$ & $\begin{array}{c}0.02 \\
(0.04)\end{array}$ & $\begin{array}{c}0.02 \\
(0.04)\end{array}$ & $\begin{array}{c}0.02 \\
(0.04)\end{array}$ & $\begin{array}{l}0.004 \\
(0.04)\end{array}$ & $\begin{array}{l}0.006 \\
(0.04)\end{array}$ \\
\hline g-ideo & & & $\begin{array}{l}0.0004 \\
(0.00)\end{array}$ & $\begin{array}{l}0.0005 \\
(0.00)\end{array}$ & $\begin{array}{c}0.0004 \\
(0.00)\end{array}$ & $\begin{array}{l}0.0004 \\
(0.00)\end{array}$ & $\begin{array}{c}0.0004 \\
(0.00)\end{array}$ & $\begin{array}{c}0.0005 \\
(0.00)\end{array}$ \\
\hline c-ideo & & & $\begin{array}{l}0.001 \\
(0.00)\end{array}$ & $\begin{array}{l}0.001 \\
(0.00)\end{array}$ & $\begin{array}{l}0.001 \\
(0.00)\end{array}$ & $\begin{array}{l}0.001 \\
(0.00)\end{array}$ & $\begin{array}{l}-0.002 \\
(0.00)\end{array}$ & $\begin{array}{l}-0.002 \\
(0.00)\end{array}$ \\
\hline $\operatorname{lngp}$ & & & & & $\begin{array}{c}0.07 \\
(0.23)\end{array}$ & $\begin{array}{c}0.08 \\
(0.23)\end{array}$ & $\begin{array}{l}-0.03 \\
(0.20)\end{array}$ & $\begin{array}{l}-0.03 \\
(0.20)\end{array}$ \\
\hline$e-i m p$ & & & & & & & $\begin{array}{c}-0.41 \\
(0.12)\end{array}$ & $\begin{array}{l}-0.41 \\
(0.12)\end{array}$ \\
\hline Observations & 1157 & 1157 & 1157 & 1157 & 1157 & 1157 & 1157 & 1157 \\
\hline State fixed effects & Yes & Yes & Yes & Yes & Yes & Yes & Yes & Yes \\
\hline Year fixed effects & Yes & Yes & Yes & Yes & Yes & Yes & Yes & Yes \\
\hline Adj R-squared & 0.35 & 0.35 & 0.35 & 0.35 & 0.35 & 0.35 & 0.45 & 0.45 \\
\hline
\end{tabular}

Notes: The dependent variable is logged per capita carbon dioxide emissions from electricity sector. Robust standard errors are clustered at the state level in parentheses. 
Table C4.2: Estimated Determinants of How RPS Requirements Relate to $\mathrm{CO}_{2}$ Emissions from the Electricity Sector

\begin{tabular}{|c|c|c|c|c|c|c|c|c|}
\hline & (1) & (2) & (3) & (4) & (5) & (6) & (7) & (8) \\
\hline$a-r p s$ & $\begin{array}{l}-0.02 \\
(0.06)\end{array}$ & & $\begin{array}{l}-0.03 \\
(0.06)\end{array}$ & & $\begin{array}{l}-0.03 \\
(0.06)\end{array}$ & & $\begin{array}{l}-0.02 \\
(0.05)\end{array}$ & \\
\hline$r$-rps & $\begin{array}{l}8.68 \\
(7.30)\end{array}$ & $\begin{array}{l}8.68 \\
(7.30)\end{array}$ & $\begin{array}{l}9.31 \\
(7.16)\end{array}$ & $\begin{array}{l}9.31 \\
(7.16)\end{array}$ & $\begin{array}{l}9.29 \\
(7.32)\end{array}$ & $\begin{array}{l}9.29 \\
(7.32)\end{array}$ & $\begin{array}{l}8.32 \\
(6.29)\end{array}$ & $\begin{array}{l}8.32 \\
(6.29)\end{array}$ \\
\hline$r$-rps $\times i-r e p$ & $\begin{array}{l}-0.003 \\
(0.64)\end{array}$ & $\begin{array}{l}-0.003 \\
(0.64)\end{array}$ & $\begin{array}{l}0.10 \\
(0.67)\end{array}$ & $\begin{array}{l}0.10 \\
(0.67)\end{array}$ & $\begin{array}{l}0.10 \\
(0.67)\end{array}$ & $\begin{array}{l}0.10 \\
(0.67)\end{array}$ & $\begin{array}{l}-0.16 \\
(0.56)\end{array}$ & $\begin{array}{l}-0.16 \\
(0.56)\end{array}$ \\
\hline$r$-rps $\times d$-rep & $\begin{array}{l}0.84 \\
(0.71)\end{array}$ & $\begin{array}{l}0.84 \\
(0.71)\end{array}$ & $\begin{array}{l}0.80 \\
(0.70)\end{array}$ & $\begin{array}{l}0.80 \\
(0.70)\end{array}$ & $\begin{array}{l}0.79 \\
(0.70)\end{array}$ & $\begin{array}{l}0.79 \\
(0.70)\end{array}$ & $\begin{array}{l}0.92 \\
(0.62)\end{array}$ & $\begin{array}{l}0.92 \\
(0.62)\end{array}$ \\
\hline$r$-rps $\times w$-inter & $\begin{array}{l}-6.72 \\
(2.36)\end{array}$ & $\begin{array}{l}-6.72 \\
(2.36)\end{array}$ & $\begin{array}{l}-6.94 \\
(2.26)\end{array}$ & $\begin{array}{l}-6.94 \\
(2.26)\end{array}$ & $\begin{array}{l}-6.92 \\
(2.35)\end{array}$ & $\begin{array}{l}-6.92 \\
(2.35)\end{array}$ & $\begin{array}{l}-6.57 \\
(2.03)\end{array}$ & $\begin{array}{l}-6.57 \\
(2.03)\end{array}$ \\
\hline$A C P$ & $\begin{array}{l}0.06 \\
(0.08)\end{array}$ & $\begin{array}{l}0.06 \\
(0.08)\end{array}$ & $\begin{array}{l}0.06 \\
(0.07)\end{array}$ & $\begin{array}{l}0.06 \\
(0.07)\end{array}$ & $\begin{array}{l}0.06 \\
(0.07)\end{array}$ & $\begin{array}{l}0.06 \\
(0.07)\end{array}$ & $\begin{array}{l}0.01 \\
(0.06)\end{array}$ & $\begin{array}{l}0.01 \\
(0.06)\end{array}$ \\
\hline Multiplier & $\begin{array}{l}0.12 \\
(0.07)\end{array}$ & $\begin{array}{l}0.12 \\
(0.07)\end{array}$ & $\begin{array}{l}0.13 \\
(0.08)\end{array}$ & $\begin{array}{l}0.13 \\
(0.08)\end{array}$ & $\begin{array}{l}0.13 \\
(0.08)\end{array}$ & $\begin{array}{l}0.13 \\
(0.08)\end{array}$ & $\begin{array}{l}0.15 \\
(0.06)\end{array}$ & $\begin{array}{l}0.15 \\
(0.06)\end{array}$ \\
\hline Carveout & $\begin{array}{l}-0.13 \\
(0.08)\end{array}$ & $\begin{array}{l}-0.13 \\
(0.08)\end{array}$ & $\begin{array}{l}-0.13 \\
(0.08)\end{array}$ & $\begin{array}{l}-0.13 \\
(0.08)\end{array}$ & $\begin{array}{l}-0.13 \\
(0.08)\end{array}$ & $\begin{array}{l}-0.13 \\
(0.08)\end{array}$ & $\begin{array}{l}-0.11 \\
(0.06)\end{array}$ & $\begin{array}{l}-0.11 \\
(0.06)\end{array}$ \\
\hline Trading & $\begin{array}{l}0.00 \\
(0.00)\end{array}$ & $\begin{array}{l}-0.02 \\
(0.06)\end{array}$ & $\begin{array}{l}0.00 \\
(0.00)\end{array}$ & $\begin{array}{l}-0.03 \\
(0.06)\end{array}$ & $\begin{array}{l}0.00 \\
(0.00)\end{array}$ & $\begin{array}{l}-0.03 \\
(0.06)\end{array}$ & $\begin{array}{l}0.00 \\
(0.00)\end{array}$ & $\begin{array}{l}-0.02 \\
(0.06)\end{array}$ \\
\hline Lhdd & $\begin{array}{l}0.04 \\
(0.17)\end{array}$ & $\begin{array}{l}0.05 \\
(0.17)\end{array}$ & $\begin{array}{l}0.07 \\
(0.17)\end{array}$ & $\begin{array}{l}0.07 \\
(0.17)\end{array}$ & $\begin{array}{l}0.07 \\
(0.16)\end{array}$ & $\begin{array}{l}0.07 \\
(0.16)\end{array}$ & $\begin{array}{l}0.01 \\
(0.16)\end{array}$ & $\begin{array}{l}0.01 \\
(0.16)\end{array}$ \\
\hline lcdd & $\begin{array}{l}-0.01 \\
(0.06)\end{array}$ & $\begin{array}{l}-0.005 \\
(0.06)\end{array}$ & $\begin{array}{l}0.01 \\
(0.06)\end{array}$ & $\begin{array}{l}0.005 \\
(0.06)\end{array}$ & $\begin{array}{l}0.01 \\
(0.07)\end{array}$ & $\begin{array}{l}0.01 \\
(0.07)\end{array}$ & $\begin{array}{l}0.01 \\
(0.06)\end{array}$ & $\begin{array}{l}0.01 \\
(0.06)\end{array}$ \\
\hline lpop & $\begin{array}{l}-1.76 \\
(0.55)\end{array}$ & $\begin{array}{l}-1.76 \\
(0.5)\end{array}$ & $\begin{array}{l}-1.99 \\
(0.50)\end{array}$ & $\begin{array}{l}-1.99 \\
(0.50)\end{array}$ & $\begin{array}{l}-1.99 \\
(0.51)\end{array}$ & $\begin{array}{l}-1.99 \\
(0.51)\end{array}$ & $\begin{array}{l}-2.09 \\
(0.40)\end{array}$ & $\begin{array}{l}-2.09 \\
(0.40)\end{array}$ \\
\hline hlcv & & & $\begin{array}{l}0.00 \\
(0.00)\end{array}$ & $\begin{array}{l}0.00 \\
(0.00)\end{array}$ & $\begin{array}{l}0.00 \\
(0.00)\end{array}$ & $\begin{array}{l}0.00 \\
(0.00)\end{array}$ & $\begin{array}{l}0.0002 \\
(0.00)\end{array}$ & $\begin{array}{l}0.0002 \\
(0.00)\end{array}$ \\
\hline slcv & & & $\begin{array}{l}-0.0002 \\
(0.00)\end{array}$ & $\begin{array}{l}-0.0002 \\
(0.00)\end{array}$ & $\begin{array}{l}-0.0002 \\
(0.00)\end{array}$ & $\begin{array}{l}-0.0002 \\
(0.00)\end{array}$ & $\begin{array}{l}-0.0002 \\
(0.00)\end{array}$ & $\begin{array}{l}-0.0002 \\
(0.00)\end{array}$ \\
\hline eres & & & $\begin{array}{l}-0.05 \\
(0.05)\end{array}$ & $\begin{array}{l}-0.05 \\
(0.05)\end{array}$ & $\begin{array}{l}-0.05 \\
(0.05)\end{array}$ & $\begin{array}{l}-0.05 \\
(0.05)\end{array}$ & $\begin{array}{l}-0.06 \\
(0.04)\end{array}$ & $\begin{array}{l}-0.06 \\
(0.04)\end{array}$ \\
\hline ees & & & $\begin{array}{l}-0.06 \\
(0.06)\end{array}$ & $\begin{array}{l}-0.06 \\
(0.06)\end{array}$ & $\begin{array}{l}-0.06 \\
(0.06)\end{array}$ & $\begin{array}{l}-0.06 \\
(0.06)\end{array}$ & $\begin{array}{l}-0.09 \\
(0.05)\end{array}$ & $\begin{array}{l}-0.09 \\
(0.05)\end{array}$ \\
\hline$c t i$ & & & $\begin{array}{l}0.01 \\
(0.05)\end{array}$ & $\begin{array}{l}0.01 \\
(0.05)\end{array}$ & $\begin{array}{l}0.01 \\
(0.05)\end{array}$ & $\begin{array}{l}0.01 \\
(0.05)\end{array}$ & $\begin{array}{l}0.03 \\
(0.04)\end{array}$ & $\begin{array}{l}0.03 \\
(0.04)\end{array}$ \\
\hline spf & & & $\begin{array}{l}0.03 \\
(0.05)\end{array}$ & $\begin{array}{l}0.03 \\
(0.05)\end{array}$ & $\begin{array}{l}0.03 \\
(0.05)\end{array}$ & $\begin{array}{l}0.03 \\
(0.05)\end{array}$ & $\begin{array}{l}0.03 \\
(0.05)\end{array}$ & $\begin{array}{l}0.03 \\
(0.05)\end{array}$ \\
\hline$g$-ideo & & & $\begin{array}{l}0.0004 \\
(0.00)\end{array}$ & $\begin{array}{l}0.0004 \\
(0.00)\end{array}$ & $\begin{array}{l}0.0004 \\
(0.00)\end{array}$ & $\begin{array}{l}0.0004 \\
(0.00)\end{array}$ & $\begin{array}{l}0.001 \\
(0.00)\end{array}$ & $\begin{array}{l}0.001 \\
(0.00)\end{array}$ \\
\hline c-ideo & & & $\begin{array}{l}0.002 \\
(0.00)\end{array}$ & $\begin{array}{l}0.00 \\
(0.00)\end{array}$ & $\begin{array}{l}0.002 \\
(0.00)\end{array}$ & $\begin{array}{l}0.002 \\
(0.00)\end{array}$ & $\begin{array}{l}-0.001 \\
(0.00)\end{array}$ & $\begin{array}{l}-0.001 \\
(0.00)\end{array}$ \\
\hline $\operatorname{lngp}$ & & & & & $\begin{array}{l}0.02 \\
(0.21)\end{array}$ & $\begin{array}{l}0.02 \\
(0.21)\end{array}$ & $\begin{array}{l}-0.08 \\
(0.19)\end{array}$ & $\begin{array}{l}-0.08 \\
(0.19)\end{array}$ \\
\hline$e-i m p$ & & & & & & & $\begin{array}{l}-0.42 \\
(0.12)\end{array}$ & $\begin{array}{l}-0.42 \\
(0.12)\end{array}$ \\
\hline Observations & 1157 & 1157 & 1157 & 1157 & 1157 & 1157 & 1157 & 1157 \\
\hline State fixed effects & Yes & Yes & Yes & Yes & Yes & Yes & Yes & Yes \\
\hline Year fixed effects & Yes & Yes & Yes & Yes & Yes & Yes & Yes & Yes \\
\hline Adj R-squared & 0.37 & 0.37 & 0.37 & 0.37 & 0.37 & 0.37 & 0.48 & 0.48 \\
\hline
\end{tabular}

Notes: The dependent variable is logged per capita carbon dioxide emissions from electricity sector. Robust standard errors are clustered at the state level in parentheses. 
Table C5.1: Estimated Determinants of How RPS Requirements Relate to Fossil-Fuel Electricity

\begin{tabular}{|c|c|c|c|c|c|c|c|c|}
\hline & (1) & (2) & (3) & (4) & (5) & (6) & (7) & (8) \\
\hline$a-r p s$ & $\begin{array}{l}-0.03 \\
(0.06)\end{array}$ & & $\begin{array}{l}-0.04 \\
(0.06)\end{array}$ & & $\begin{array}{c}-0.04 \\
(0.06)\end{array}$ & & $\begin{array}{l}-0.03 \\
(0.06)\end{array}$ & \\
\hline$r$-rps & $\begin{array}{c}24.7 \\
(11.3)\end{array}$ & $\begin{array}{c}25.0 \\
(11.6)\end{array}$ & $\begin{array}{c}22.9 \\
(11.2)\end{array}$ & $\begin{array}{c}23.0 \\
(11.4)\end{array}$ & $\begin{array}{c}23.1 \\
(11.4)\end{array}$ & $\begin{array}{c}23.3 \\
(11.5)\end{array}$ & $\begin{array}{c}20.4 \\
(9.67)\end{array}$ & $\begin{array}{c}20.6 \\
(9.80)\end{array}$ \\
\hline$r$-rps $\times i$-rep & $\begin{array}{l}-10.0 \\
(4.00)\end{array}$ & $\begin{array}{l}-10.2 \\
(4.09)\end{array}$ & $\begin{array}{l}-9.83 \\
(3.83)\end{array}$ & $\begin{array}{l}-9.94 \\
(3.91)\end{array}$ & $\begin{array}{l}-9.94 \\
(3.94)\end{array}$ & $\begin{array}{l}-10.1 \\
(4.00)\end{array}$ & $\begin{array}{l}-8.87 \\
(3.28)\end{array}$ & $\begin{array}{l}-8.97 \\
(3.34)\end{array}$ \\
\hline$r$-rps $\times d$-rep & $\begin{array}{c}1.01 \\
(0.68)\end{array}$ & $\begin{array}{l}1.05 \\
(0.68)\end{array}$ & $\begin{array}{l}1.09 \\
(0.68)\end{array}$ & $\begin{array}{c}1.11 \\
(0.68)\end{array}$ & $\begin{array}{c}1.10 \\
(0.68)\end{array}$ & $\begin{array}{c}1.12 \\
(0.67)\end{array}$ & $\begin{array}{c}1.24 \\
(0.51)\end{array}$ & $\begin{array}{c}1.26 \\
(0.51)\end{array}$ \\
\hline$r$-rps $\times w$-inter & $\begin{array}{l}-1.16 \\
(0.82)\end{array}$ & $\begin{array}{l}-1.22 \\
(0.85)\end{array}$ & $\begin{array}{l}-1.12 \\
(0.82)\end{array}$ & $\begin{array}{l}-1.15 \\
(0.84)\end{array}$ & $\begin{array}{l}-1.12 \\
(0.82)\end{array}$ & $\begin{array}{l}-1.16 \\
(0.84)\end{array}$ & $\begin{array}{l}-1.48 \\
(0.59)\end{array}$ & $\begin{array}{l}-1.52 \\
(0.61)\end{array}$ \\
\hline lhdd & $\begin{array}{c}0.10 \\
(0.22)\end{array}$ & $\begin{array}{c}0.10 \\
(0.22)\end{array}$ & $\begin{array}{c}0.06 \\
(0.21)\end{array}$ & $\begin{array}{c}0.06 \\
(0.22)\end{array}$ & $\begin{array}{c}0.06 \\
(0.21)\end{array}$ & $\begin{array}{l}0.058 \\
(0.21)\end{array}$ & $\begin{array}{c}-0.0002 \\
(0.21)\end{array}$ & $\begin{array}{l}-0.004 \\
(0.22)\end{array}$ \\
\hline lcdd & $\begin{array}{l}-0.05 \\
(0.21)\end{array}$ & $\begin{array}{l}-0.06 \\
(0.21)\end{array}$ & $\begin{array}{l}-0.04 \\
(0.21)\end{array}$ & $\begin{array}{l}-0.05 \\
(0.21)\end{array}$ & $\begin{array}{l}-0.05 \\
(0.22)\end{array}$ & $\begin{array}{l}-0.05 \\
(0.22)\end{array}$ & $\begin{array}{l}-0.04 \\
(0.21)\end{array}$ & $\begin{array}{l}-0.04 \\
(0.21)\end{array}$ \\
\hline lpop & $\begin{array}{c}1.35 \\
(1.48)\end{array}$ & $\begin{array}{c}1.36 \\
(1.49)\end{array}$ & $\begin{array}{l}1.27 \\
(1.47)\end{array}$ & $\begin{array}{c}1.25 \\
(1.48)\end{array}$ & $\begin{array}{c}1.30 \\
(1.50)\end{array}$ & $\begin{array}{c}1.28 \\
(1.50)\end{array}$ & $\begin{array}{l}1.25 \\
(1.35)\end{array}$ & $\begin{array}{c}1.23 \\
(1.36)\end{array}$ \\
\hline hlcv & & & $\begin{array}{l}0.001 \\
(0.00)\end{array}$ & $\begin{array}{l}0.001 \\
(0.00)\end{array}$ & $\begin{array}{l}0.001 \\
(0.00)\end{array}$ & $\begin{array}{l}0.001 \\
(0.00)\end{array}$ & $\begin{array}{l}0.002 \\
(0.00)\end{array}$ & $\begin{array}{l}0.002 \\
(0.00)\end{array}$ \\
\hline slcv & & & $\begin{array}{l}0.001 \\
(0.00)\end{array}$ & $\begin{array}{l}0.001 \\
(0.00)\end{array}$ & $\begin{array}{l}0.001 \\
(0.00)\end{array}$ & $\begin{array}{l}0.001 \\
(0.00)\end{array}$ & $\begin{array}{c}0.001 \\
(0.001)\end{array}$ & $\begin{array}{l}0.001 \\
(0.00)\end{array}$ \\
\hline eres & & & $\begin{array}{c}0.07 \\
(0.08)\end{array}$ & $\begin{array}{c}0.07 \\
(0.08)\end{array}$ & $\begin{array}{c}0.07 \\
(0.08)\end{array}$ & $\begin{array}{c}0.07 \\
(0.08)\end{array}$ & $\begin{array}{c}0.03 \\
(0.06)\end{array}$ & $\begin{array}{c}0.03 \\
(0.07)\end{array}$ \\
\hline ees & & & $\begin{array}{l}-0.08 \\
(0.06)\end{array}$ & $\begin{array}{l}-0.08 \\
(0.06)\end{array}$ & $\begin{array}{l}-0.08 \\
(0.06)\end{array}$ & $\begin{array}{l}-0.08 \\
(0.06)\end{array}$ & $\begin{array}{l}-0.12 \\
(0.05)\end{array}$ & $\begin{array}{l}-0.12 \\
(0.05)\end{array}$ \\
\hline$c t i$ & & & $\begin{array}{l}-0.03 \\
(0.08)\end{array}$ & $\begin{array}{l}-0.03 \\
(0.08)\end{array}$ & $\begin{array}{l}-0.03 \\
(0.08)\end{array}$ & $\begin{array}{l}-0.03 \\
(0.08)\end{array}$ & $\begin{array}{c}0.01 \\
(0.07)\end{array}$ & $\begin{array}{l}0.005 \\
(0.07)\end{array}$ \\
\hline spf & & & $\begin{array}{l}-0.05 \\
(0.07)\end{array}$ & $\begin{array}{l}-0.05 \\
(0.07)\end{array}$ & $\begin{array}{l}-0.05 \\
(0.08)\end{array}$ & $\begin{array}{l}-0.05 \\
(0.08)\end{array}$ & $\begin{array}{l}-0.06 \\
(0.07)\end{array}$ & $\begin{array}{l}-0.07 \\
(0.07)\end{array}$ \\
\hline g-ideo & & & $\begin{array}{l}0.0003 \\
(0.00)\end{array}$ & $\begin{array}{c}0.0002 \\
(0.00)\end{array}$ & $\begin{array}{c}0.0003 \\
(0.00)\end{array}$ & $\begin{array}{l}0.0002 \\
(0.00)\end{array}$ & $\begin{array}{c}0.0003 \\
(0.00)\end{array}$ & $\begin{array}{l}0.0002 \\
(0.00)\end{array}$ \\
\hline c-ideo & & & $\begin{array}{l}-0.002 \\
(0.00)\end{array}$ & $\begin{array}{l}-0.002 \\
(0.01)\end{array}$ & $\begin{array}{l}-0.002 \\
(0.00)\end{array}$ & $\begin{array}{l}-0.002 \\
(0.00)\end{array}$ & $\begin{array}{l}-0.006 \\
(0.00)\end{array}$ & $\begin{array}{l}-0.01 \\
(0.00)\end{array}$ \\
\hline $\operatorname{lngp}$ & & & & & $\begin{array}{c}-0.11 \\
(0.46)\end{array}$ & $\begin{array}{l}-0.11 \\
(0.46)\end{array}$ & $\begin{array}{l}-0.25 \\
(0.43)\end{array}$ & $\begin{array}{c}-0.25 \\
(0.43)\end{array}$ \\
\hline$e$-imp & & & & & & & $\begin{array}{l}-0.59 \\
(0.15)\end{array}$ & $\begin{array}{c}-0.59 \\
(0.15)\end{array}$ \\
\hline Observations & 1196 & 1196 & 1196 & 1196 & 1196 & 1196 & 1196 & 1196 \\
\hline State fixed effects & Yes & Yes & Yes & Yes & Yes & Yes & Yes & Yes \\
\hline Year fixed effects & Yes & Yes & Yes & Yes & Yes & Yes & Yes & Yes \\
\hline Adj R-squared & 0.13 & 0.13 & 0.14 & 0.14 & 0.14 & 0.14 & 0.25 & 0.25 \\
\hline
\end{tabular}

Notes: The dependent variable is logged fossil-fuel electricity per capita. Robust standard errors are clustered at the state level in parentheses. 
Table C5.2: Estimated Determinants of How RPS Requirements Relate to Fossil-Fuel Electricity

\begin{tabular}{|c|c|c|c|c|c|c|c|c|}
\hline & (1) & (2) & (3) & (4) & (5) & (6) & (7) & (8) \\
\hline$a-r p s$ & $\begin{array}{l}-0.05 \\
(0.07)\end{array}$ & & $\begin{array}{l}-0.02 \\
(0.09)\end{array}$ & & $\begin{array}{l}-0.02 \\
(0.08)\end{array}$ & & $\begin{array}{l}0.001 \\
(0.07)\end{array}$ & \\
\hline$r$-rps & $\begin{array}{l}22.5 \\
(11.0)\end{array}$ & $\begin{array}{l}22.5 \\
(11.0)\end{array}$ & $\begin{array}{l}21.5 \\
(10.8)\end{array}$ & $\begin{array}{l}21.5 \\
(10.8)\end{array}$ & $\begin{array}{l}21.7 \\
(10.8)\end{array}$ & $\begin{array}{l}21.7 \\
(10.8)\end{array}$ & $\begin{array}{l}20.1 \\
(9.42)\end{array}$ & $\begin{array}{l}20.1 \\
(9.42)\end{array}$ \\
\hline$r$-rps $\times i-r e p$ & $\begin{array}{l}-0.93 \\
(0.78)\end{array}$ & $\begin{array}{l}-0.93 \\
(0.78)\end{array}$ & $\begin{array}{l}-0.87 \\
(0.79)\end{array}$ & $\begin{array}{l}-0.87 \\
(0.79)\end{array}$ & $\begin{array}{l}-0.87 \\
(0.79)\end{array}$ & $\begin{array}{l}-0.87 \\
(0.79)\end{array}$ & $\begin{array}{l}-1.26 \\
(0.57)\end{array}$ & $\begin{array}{l}-1.26 \\
(0.57)\end{array}$ \\
\hline$r$-rps $\times d$-rep & $\begin{array}{l}1.02 \\
(0.67)\end{array}$ & $\begin{array}{l}1.02 \\
(0.67)\end{array}$ & $\begin{array}{l}1.05 \\
(0.66)\end{array}$ & $\begin{array}{l}1.05 \\
(0.67)\end{array}$ & $\begin{array}{l}1.06 \\
(0.66)\end{array}$ & $\begin{array}{l}1.06 \\
(0.66)\end{array}$ & $\begin{array}{l}1.13 \\
(0.51)\end{array}$ & $\begin{array}{l}1.13 \\
(0.51)\end{array}$ \\
\hline$r$-rps $\times$ w-inter & $\begin{array}{l}-9.83 \\
(3.99)\end{array}$ & $\begin{array}{l}-9.83 \\
(3.99)\end{array}$ & $\begin{array}{l}-9.76 \\
(3.77)\end{array}$ & $\begin{array}{l}-9.76 \\
(3.77)\end{array}$ & $\begin{array}{l}-9.87 \\
(3.84)\end{array}$ & $\begin{array}{l}-9.87 \\
(3.84)\end{array}$ & $\begin{array}{l}-8.78 \\
(3.24)\end{array}$ & $\begin{array}{l}-8.78 \\
(3.24)\end{array}$ \\
\hline$A C P$ & $\begin{array}{l}0.15 \\
(0.09)\end{array}$ & $\begin{array}{l}0.15 \\
(0.09)\end{array}$ & $\begin{array}{l}0.13 \\
(0.08)\end{array}$ & $\begin{array}{l}0.13 \\
(0.08)\end{array}$ & $\begin{array}{l}0.13 \\
(0.08)\end{array}$ & $\begin{array}{l}0.13 \\
(0.08)\end{array}$ & $\begin{array}{l}0.06 \\
(0.07)\end{array}$ & $\begin{array}{l}0.06 \\
(0.07)\end{array}$ \\
\hline Multiplier & $\begin{array}{l}-0.01 \\
(0.10)\end{array}$ & $\begin{array}{l}-0.01 \\
(0.10)\end{array}$ & $\begin{array}{l}-0.03 \\
(0.11)\end{array}$ & $\begin{array}{l}-0.03 \\
(0.11)\end{array}$ & $\begin{array}{l}-0.02 \\
(0.11)\end{array}$ & $\begin{array}{l}-0.02 \\
(0.11)\end{array}$ & $\begin{array}{l}0.001 \\
(0.09)\end{array}$ & $\begin{array}{l}0.001 \\
(0.09)\end{array}$ \\
\hline Carveout & $\begin{array}{l}-0.12 \\
(0.09)\end{array}$ & $\begin{array}{l}-0.12 \\
(0.09)\end{array}$ & $\begin{array}{l}-0.14 \\
(0.09)\end{array}$ & $\begin{array}{l}-0.14 \\
(0.09)\end{array}$ & $\begin{array}{l}-0.14 \\
(0.09)\end{array}$ & $\begin{array}{l}-0.14 \\
(0.09)\end{array}$ & $\begin{array}{l}-0.12 \\
(0.07)\end{array}$ & $\begin{array}{l}-0.12 \\
(0.07)\end{array}$ \\
\hline Trading & $\begin{array}{l}0.00 \\
(0.00)\end{array}$ & $\begin{array}{l}-0.05 \\
(0.07)\end{array}$ & $\begin{array}{l}0.00 \\
(0.00)\end{array}$ & $\begin{array}{l}-0.02 \\
(0.09)\end{array}$ & $\begin{array}{l}0.00 \\
(0.00)\end{array}$ & $\begin{array}{l}-0.02 \\
(0.08)\end{array}$ & $\begin{array}{l}0.00 \\
(0.00)\end{array}$ & $\begin{array}{l}0.001 \\
(0.07)\end{array}$ \\
\hline lhdd & $\begin{array}{l}0.08 \\
(0.22)\end{array}$ & $\begin{array}{l}0.08 \\
(0.22)\end{array}$ & $\begin{array}{l}0.06 \\
(0.21)\end{array}$ & $\begin{array}{l}0.06 \\
(0.21)\end{array}$ & $\begin{array}{l}0.05 \\
(0.21)\end{array}$ & $\begin{array}{l}0.05 \\
(0.21)\end{array}$ & $\begin{array}{l}0.003 \\
(0.21)\end{array}$ & $\begin{array}{l}0.003 \\
(0.21)\end{array}$ \\
\hline lcdd & $\begin{array}{l}-0.06 \\
(0.21)\end{array}$ & $\begin{array}{l}-0.06 \\
(0.21)\end{array}$ & $\begin{array}{l}-0.05 \\
(0.21)\end{array}$ & $\begin{array}{l}-0.05 \\
(0.21)\end{array}$ & $\begin{array}{l}-0.06 \\
(0.22)\end{array}$ & $\begin{array}{l}-0.06 \\
(0.22)\end{array}$ & $\begin{array}{l}-0.05 \\
(0.21)\end{array}$ & $\begin{array}{l}-0.05 \\
(0.21)\end{array}$ \\
\hline lpop & $\begin{array}{l}1.59 \\
(1.60)\end{array}$ & $\begin{array}{l}1.59 \\
(1.60)\end{array}$ & $\begin{array}{l}1.53 \\
(1.61)\end{array}$ & $\begin{array}{l}1.53 \\
(1.61)\end{array}$ & $\begin{array}{l}1.55 \\
(1.63)\end{array}$ & $\begin{array}{l}1.55 \\
(1.63)\end{array}$ & $\begin{array}{l}1.36 \\
(1.50)\end{array}$ & $\begin{array}{l}1.36 \\
(1.50)\end{array}$ \\
\hline hlcv & & & $\begin{array}{l}0.001 \\
(0.00)\end{array}$ & $\begin{array}{l}0.001 \\
(0.00)\end{array}$ & $\begin{array}{l}0.001 \\
(0.00)\end{array}$ & $\begin{array}{l}0.001 \\
(0.00)\end{array}$ & $\begin{array}{l}0.002 \\
(0.00)\end{array}$ & $\begin{array}{l}0.002 \\
(0.00)\end{array}$ \\
\hline slcv & & & $\begin{array}{l}0.001 \\
(0.00)\end{array}$ & $\begin{array}{l}0.001 \\
(0.00)\end{array}$ & $\begin{array}{l}0.001 \\
(0.00)\end{array}$ & $\begin{array}{l}0.001 \\
(0.00)\end{array}$ & $\begin{array}{l}0.001 \\
(0.00)\end{array}$ & $\begin{array}{l}0.001 \\
(0.00)\end{array}$ \\
\hline eres & & & $\begin{array}{l}0.07 \\
(0.08)\end{array}$ & $\begin{array}{l}0.07 \\
(0.08)\end{array}$ & $\begin{array}{l}0.07 \\
(0.08)\end{array}$ & $\begin{array}{l}0.07 \\
(0.08)\end{array}$ & $\begin{array}{l}0.04 \\
(0.07)\end{array}$ & $\begin{array}{l}0.04 \\
(0.07)\end{array}$ \\
\hline ees & & & $\begin{array}{l}-0.07 \\
(0.06)\end{array}$ & $\begin{array}{l}-0.07 \\
(0.06)\end{array}$ & $\begin{array}{l}-0.07 \\
(0.06)\end{array}$ & $\begin{array}{l}-0.07 \\
(0.06)\end{array}$ & $\begin{array}{l}-0.11 \\
(0.05)\end{array}$ & $\begin{array}{l}-0.11 \\
(0.05)\end{array}$ \\
\hline cti & & & $\begin{array}{l}-0.03 \\
(0.07)\end{array}$ & $\begin{array}{l}-0.04 \\
(0.07)\end{array}$ & $\begin{array}{l}-0.04 \\
(0.07)\end{array}$ & $\begin{array}{l}-0.04 \\
(0.07)\end{array}$ & $\begin{array}{l}-0.004 \\
(0.07)\end{array}$ & $\begin{array}{l}-0.004 \\
(0.07)\end{array}$ \\
\hline $\operatorname{spf}$ & & & $\begin{array}{l}-0.06 \\
(0.08)\end{array}$ & $\begin{array}{l}-0.06 \\
(0.08)\end{array}$ & $\begin{array}{l}-0.06 \\
(0.08)\end{array}$ & $\begin{array}{l}-0.06 \\
(0.08)\end{array}$ & $\begin{array}{l}-0.07 \\
(0.08)\end{array}$ & $\begin{array}{l}-0.07 \\
(0.08)\end{array}$ \\
\hline$g$-ideo & & & $\begin{array}{l}0.0001 \\
(0.00)\end{array}$ & $\begin{array}{l}0.0001 \\
(0.00)\end{array}$ & $\begin{array}{l}0.0002 \\
(0.00)\end{array}$ & $\begin{array}{l}0.0002 \\
(0.00)\end{array}$ & $\begin{array}{l}0.0003 \\
(0.00)\end{array}$ & $\begin{array}{l}0.0003 \\
(0.00)\end{array}$ \\
\hline c-ideo & & & $\begin{array}{l}-0.002 \\
(0.00)\end{array}$ & $\begin{array}{l}-0.002 \\
(0.00)\end{array}$ & $\begin{array}{l}-0.002 \\
(0.00)\end{array}$ & $\begin{array}{l}-0.002 \\
(0.00)\end{array}$ & $\begin{array}{l}-0.01 \\
(0.00)\end{array}$ & $\begin{array}{l}-0.01 \\
(0.00)\end{array}$ \\
\hline $\operatorname{lngp}$ & & & & & $\begin{array}{l}-0.13 \\
(0.45)\end{array}$ & $\begin{array}{l}-0.13 \\
(0.45)\end{array}$ & $\begin{array}{l}-0.26 \\
(0.42)\end{array}$ & $\begin{array}{l}-0.26 \\
(0.42)\end{array}$ \\
\hline$e$-imp & & & & & & & $\begin{array}{l}-0.58 \\
(0.15)\end{array}$ & $\begin{array}{l}-0.58 \\
(0.15)\end{array}$ \\
\hline Observations & 1196 & 1196 & 1196 & 1196 & 1196 & 1196 & 1196 & 1196 \\
\hline State fixed effects & Yes & Yes & Yes & Yes & Yes & Yes & Yes & Yes \\
\hline Year fixed effects & Yes & Yes & Yes & Yes & Yes & Yes & Yes & Yes \\
\hline Adj R-squared & 0.14 & 0.14 & 0.15 & 0.15 & 0.15 & 0.15 & 0.26 & 0.26 \\
\hline
\end{tabular}

Notes: The dependent variable is logged fossil-fuel electricity per capita. Robust standard errors are clustered at the state level in parentheses. 
Table C6.1: Estimated Determinants of How RPS Requirements Relate to Dispatchable Renewable Generation

\begin{tabular}{|c|c|c|c|c|c|c|c|c|}
\hline & (1) & (2) & (3) & (4) & (5) & (6) & (7) & (8) \\
\hline$a-r p s$ & $\begin{array}{c}0.03 \\
(0.03)\end{array}$ & & $\begin{array}{c}0.03 \\
(0.03)\end{array}$ & & $\begin{array}{c}0.03 \\
(0.03)\end{array}$ & & $\begin{array}{c}0.03 \\
(0.03)\end{array}$ & \\
\hline$r$-rps & $\begin{array}{c}0.36 \\
(7.01)\end{array}$ & $\begin{array}{c}0.13 \\
(6.74)\end{array}$ & $\begin{array}{l}-1.78 \\
(5.77)\end{array}$ & $\begin{array}{l}-1.94 \\
(5.62)\end{array}$ & $\begin{array}{l}-2.07 \\
(5.68)\end{array}$ & $\begin{array}{l}-2.24 \\
(5.52)\end{array}$ & $\begin{array}{l}-2.16 \\
(5.69)\end{array}$ & $\begin{array}{l}-2.33 \\
(5.53)\end{array}$ \\
\hline$r$-rps $\times i$-rep & $\begin{array}{l}-0.81 \\
(0.54)\end{array}$ & $\begin{array}{l}-0.76 \\
(0.55)\end{array}$ & $\begin{array}{l}-0.72 \\
(0.45)\end{array}$ & $\begin{array}{l}-0.69 \\
(0.44)\end{array}$ & $\begin{array}{l}-0.69 \\
(0.45)\end{array}$ & $\begin{array}{l}-0.67 \\
(0.44)\end{array}$ & $\begin{array}{l}-0.71 \\
(0.45)\end{array}$ & $\begin{array}{l}-0.68 \\
(0.45)\end{array}$ \\
\hline$r$-rps $\times d$-rep & $\begin{array}{c}0.73 \\
(0.49)\end{array}$ & $\begin{array}{c}0.70 \\
(0.49)\end{array}$ & $\begin{array}{c}0.73 \\
(0.42)\end{array}$ & $\begin{array}{c}0.72 \\
(0.41)\end{array}$ & $\begin{array}{c}0.69 \\
(0.40)\end{array}$ & $\begin{array}{c}0.67 \\
(0.39)\end{array}$ & $\begin{array}{c}0.69 \\
(0.40)\end{array}$ & $\begin{array}{c}0.68 \\
(0.39)\end{array}$ \\
\hline$r$-rps $\times w$-inter & $\begin{array}{l}-1.55 \\
(2.34)\end{array}$ & $\begin{array}{l}-1.39 \\
(2.22)\end{array}$ & $\begin{array}{l}-1.07 \\
(1.85)\end{array}$ & $\begin{array}{l}-0.98 \\
(1.78)\end{array}$ & $\begin{array}{l}-0.83 \\
(1.82)\end{array}$ & $\begin{array}{l}-0.74 \\
(1.75)\end{array}$ & $\begin{array}{l}-0.80 \\
(1.86)\end{array}$ & $\begin{array}{l}-0.71 \\
(1.78)\end{array}$ \\
\hline lhdd & $\begin{array}{c}0.42 \\
(0.26)\end{array}$ & $\begin{array}{c}0.42 \\
(0.26)\end{array}$ & $\begin{array}{c}0.35 \\
(0.25)\end{array}$ & $\begin{array}{c}0.35 \\
(0.25)\end{array}$ & $\begin{array}{c}0.35 \\
(0.25)\end{array}$ & $\begin{array}{c}0.35 \\
(0.25)\end{array}$ & $\begin{array}{c}0.35 \\
(0.25)\end{array}$ & $\begin{array}{c}0.35 \\
(0.25)\end{array}$ \\
\hline lcdd & $\begin{array}{l}-0.09 \\
(0.08)\end{array}$ & $\begin{array}{l}-0.09 \\
(0.08)\end{array}$ & $\begin{array}{l}-0.10 \\
(0.08)\end{array}$ & $\begin{array}{l}-0.10 \\
(0.08)\end{array}$ & $\begin{array}{l}-0.10 \\
(0.09)\end{array}$ & $\begin{array}{l}-0.10 \\
(0.09)\end{array}$ & $\begin{array}{l}-0.11 \\
(0.09)\end{array}$ & $\begin{array}{l}-0.10 \\
(0.09)\end{array}$ \\
\hline lpop & $\begin{array}{l}-1.87 \\
(0.47)\end{array}$ & $\begin{array}{l}-1.88 \\
(0.47)\end{array}$ & $\begin{array}{l}-1.59 \\
(0.43)\end{array}$ & $\begin{array}{l}-1.57 \\
(0.43)\end{array}$ & $\begin{array}{l}-1.63 \\
(0.44)\end{array}$ & $\begin{array}{l}-1.62 \\
(0.44)\end{array}$ & $\begin{array}{l}-1.64 \\
(0.45)\end{array}$ & $\begin{array}{l}-1.62 \\
(0.45)\end{array}$ \\
\hline hlcv & & & $\begin{array}{l}-0.002 \\
(0.00)\end{array}$ & $\begin{array}{l}-0.002 \\
(0.00)\end{array}$ & $\begin{array}{l}-0.002 \\
(0.00)\end{array}$ & $\begin{array}{c}-0.002 \\
(0.00)\end{array}$ & $\begin{array}{l}-0.002 \\
(0.00)\end{array}$ & $\begin{array}{l}-0.002 \\
(0.00)\end{array}$ \\
\hline slcv & & & $\begin{array}{c}-0.0004 \\
(0.00)\end{array}$ & $\begin{array}{c}-0.0004 \\
(0.00)\end{array}$ & $\begin{array}{c}-0.0005 \\
(0.00)\end{array}$ & $\begin{array}{c}-0.0004 \\
(0.00)\end{array}$ & $\begin{array}{c}-0.0005 \\
(0.00)\end{array}$ & $\begin{array}{c}-0.0004 \\
(0.00)\end{array}$ \\
\hline eres & & & $\begin{array}{c}0.08 \\
(0.05)\end{array}$ & $\begin{array}{c}0.08 \\
(0.05)\end{array}$ & $\begin{array}{c}0.08 \\
(0.05)\end{array}$ & $\begin{array}{c}0.08 \\
(0.05)\end{array}$ & $\begin{array}{c}0.07 \\
(0.04)\end{array}$ & $\begin{array}{c}0.08 \\
(0.05)\end{array}$ \\
\hline ees & & & $\begin{array}{l}-0.03 \\
(0.04)\end{array}$ & $\begin{array}{l}-0.02 \\
(0.03)\end{array}$ & $\begin{array}{l}-0.03 \\
(0.04)\end{array}$ & $\begin{array}{l}-0.02 \\
(0.03)\end{array}$ & $\begin{array}{l}-0.03 \\
(0.04)\end{array}$ & $\begin{array}{l}-0.02 \\
(0.03)\end{array}$ \\
\hline$c t i$ & & & $\begin{array}{l}-0.12 \\
(0.04)\end{array}$ & $\begin{array}{l}-0.11 \\
(0.04)\end{array}$ & $\begin{array}{l}-0.11 \\
(0.04)\end{array}$ & $\begin{array}{l}-0.11 \\
(0.04)\end{array}$ & $\begin{array}{l}-0.11 \\
(0.04)\end{array}$ & $\begin{array}{l}-0.11 \\
(0.04)\end{array}$ \\
\hline$s p f$ & & & $\begin{array}{c}0.02 \\
(0.05)\end{array}$ & $\begin{array}{c}0.02 \\
(0.05)\end{array}$ & $\begin{array}{c}0.02 \\
(0.05)\end{array}$ & $\begin{array}{c}0.02 \\
(0.05)\end{array}$ & $\begin{array}{c}0.02 \\
(0.05)\end{array}$ & $\begin{array}{c}0.02 \\
(0.05)\end{array}$ \\
\hline g-ideo & & & $\begin{array}{l}0.002 \\
(0.00)\end{array}$ & $\begin{array}{l}0.002 \\
(0.00)\end{array}$ & $\begin{array}{l}0.002 \\
(0.00)\end{array}$ & $\begin{array}{l}0.002 \\
(0.00)\end{array}$ & $\begin{array}{l}0.001 \\
(0.00)\end{array}$ & $\begin{array}{l}0.002 \\
(0.00)\end{array}$ \\
\hline c-ideo & & & $\begin{array}{l}-0.002 \\
(0.00)\end{array}$ & $\begin{array}{l}-0.002 \\
(0.00)\end{array}$ & $\begin{array}{r}-0.002 \\
(0.00)\end{array}$ & $\begin{array}{l}-0.002 \\
(0.00)\end{array}$ & $\begin{array}{l}-0.002 \\
(0.00)\end{array}$ & $\begin{array}{l}-0.002 \\
(0.00)\end{array}$ \\
\hline $\operatorname{lngp}$ & & & & & $\begin{array}{c}0.19 \\
(0.19)\end{array}$ & $\begin{array}{c}0.19 \\
(0.19)\end{array}$ & $\begin{array}{c}0.19 \\
(0.19)\end{array}$ & $\begin{array}{c}0.18 \\
(0.19)\end{array}$ \\
\hline$e-i m p$ & & & & & & & $\begin{array}{l}-0.02 \\
(0.07)\end{array}$ & $\begin{array}{l}-0.02 \\
(0.07) \\
\end{array}$ \\
\hline Observations & 1170 & 1170 & 1170 & 1170 & 1170 & 1170 & 1170 & 1170 \\
\hline State fixed effects & Yes & Yes & Yes & Yes & Yes & Yes & Yes & Yes \\
\hline Year fixed effects & Yes & Yes & Yes & Yes & Yes & Yes & Yes & Yes \\
\hline Adj R-squared & 0.26 & 0.26 & 0.29 & 0.29 & 0.29 & 0.29 & 0.29 & 0.29 \\
\hline
\end{tabular}

Notes: The dependent variable is logged dispatchable renewable electricity generation per capita. Robust standard errors are clustered at the state level in parentheses. 
Table C6.2: Estimated Determinants of How RPS Requirements Relate to Dispatchable Renewable Generation

\begin{tabular}{|c|c|c|c|c|c|c|c|c|}
\hline & (1) & (2) & (3) & (4) & (5) & (6) & (7) & (8) \\
\hline$a-r p s$ & $\begin{array}{c}0.01 \\
(0.05)\end{array}$ & & $\begin{array}{l}0.002 \\
(0.05)\end{array}$ & & $\begin{array}{c}0.01 \\
(0.05)\end{array}$ & & $\begin{array}{c}0.01 \\
(0.05)\end{array}$ & \\
\hline$r$-rps & $\begin{array}{l}-0.09 \\
(6.97)\end{array}$ & $\begin{array}{l}-0.20 \\
(6.97)\end{array}$ & $\begin{array}{l}-2.01 \\
(5.75)\end{array}$ & $\begin{array}{l}-2.01 \\
(5.75)\end{array}$ & $\begin{array}{l}-2.22 \\
(5.65)\end{array}$ & $\begin{array}{l}-2.22 \\
(5.65)\end{array}$ & $\begin{array}{l}-2.27 \\
(5.67)\end{array}$ & $\begin{array}{l}-2.27 \\
(5.66)\end{array}$ \\
\hline$r$-rps $\times i-r e p$ & $\begin{array}{l}-0.95 \\
(0.50)\end{array}$ & $\begin{array}{l}-0.95 \\
(0.50)\end{array}$ & $\begin{array}{l}-0.81 \\
(0.45)\end{array}$ & $\begin{array}{l}-0.81 \\
(0.45)\end{array}$ & $\begin{array}{l}-0.80 \\
(0.45)\end{array}$ & $\begin{array}{l}-0.80 \\
(0.45)\end{array}$ & $\begin{array}{l}-0.82 \\
(0.45)\end{array}$ & $\begin{array}{l}-0.82 \\
(0.45)\end{array}$ \\
\hline$r$-rps $\times d$-rep & $\begin{array}{c}0.91 \\
(0.47)\end{array}$ & $\begin{array}{c}0.91 \\
(0.47)\end{array}$ & $\begin{array}{c}0.81 \\
(0.43)\end{array}$ & $\begin{array}{c}0.81 \\
(0.43)\end{array}$ & $\begin{array}{c}0.78 \\
(0.42)\end{array}$ & $\begin{array}{c}0.78 \\
(0.42)\end{array}$ & $\begin{array}{c}0.78 \\
(0.42)\end{array}$ & $\begin{array}{c}0.78 \\
(0.42)\end{array}$ \\
\hline$r$-rps $\times$ w-inter & $\begin{array}{l}-1.84 \\
(2.30)\end{array}$ & $\begin{array}{l}-1.84 \\
(2.30)\end{array}$ & $\begin{array}{l}-1.12 \\
(1.90)\end{array}$ & $\begin{array}{l}-1.12 \\
(1.90)\end{array}$ & $\begin{array}{l}-0.91 \\
(1.89)\end{array}$ & $\begin{array}{l}-0.91 \\
(1.89)\end{array}$ & $\begin{array}{l}-0.88 \\
(1.91)\end{array}$ & $\begin{array}{l}-0.88 \\
(1.91)\end{array}$ \\
\hline$A C P$ & $\begin{array}{c}0.02 \\
(0.04)\end{array}$ & $\begin{array}{c}0.02 \\
(0.04)\end{array}$ & $\begin{array}{c}0.005 \\
(0.03)\end{array}$ & $\begin{array}{l}0.005 \\
(0.03)\end{array}$ & $\begin{array}{l}0.001 \\
(0.03)\end{array}$ & $\begin{array}{l}0.001 \\
(0.03)\end{array}$ & $\begin{array}{r}-0.002 \\
(0.04)\end{array}$ & $\begin{array}{l}-0.002 \\
(0.04)\end{array}$ \\
\hline Multiplier & $\begin{array}{l}-0.04 \\
(0.05)\end{array}$ & $\begin{array}{l}-0.04 \\
(0.05)\end{array}$ & $\begin{array}{l}-0.01 \\
(0.05)\end{array}$ & $\begin{array}{l}-0.01 \\
(0.05)\end{array}$ & $\begin{array}{l}-0.01 \\
(0.05)\end{array}$ & $\begin{array}{l}-0.01 \\
(0.05)\end{array}$ & $\begin{array}{l}-0.01 \\
(0.05)\end{array}$ & $\begin{array}{l}-0.01 \\
(0.05)\end{array}$ \\
\hline Carveout & $\begin{array}{c}0.08 \\
(0.05)\end{array}$ & $\begin{array}{c}0.08 \\
(0.05)\end{array}$ & $\begin{array}{c}0.06 \\
(0.04)\end{array}$ & $\begin{array}{c}0.06 \\
(0.04)\end{array}$ & $\begin{array}{c}0.06 \\
(0.04)\end{array}$ & $\begin{array}{c}0.06 \\
(0.04)\end{array}$ & $\begin{array}{c}0.06 \\
(0.04)\end{array}$ & $\begin{array}{c}0.06 \\
(0.04)\end{array}$ \\
\hline Trading & $\begin{array}{c}0.00 \\
(0.00)\end{array}$ & $\begin{array}{c}0.01 \\
(0.05)\end{array}$ & $\begin{array}{c}0.00 \\
(0.00)\end{array}$ & $\begin{array}{l}0.002 \\
(0.05)\end{array}$ & $\begin{array}{c}0.00 \\
(0.00)\end{array}$ & $\begin{array}{c}0.01 \\
(0.05)\end{array}$ & $\begin{array}{c}0.00 \\
(0.00)\end{array}$ & $\begin{array}{l}0.008 \\
(0.05)\end{array}$ \\
\hline lhdd & $\begin{array}{c}0.42 \\
(0.26)\end{array}$ & $\begin{array}{c}0.42 \\
(0.26)\end{array}$ & $\begin{array}{c}0.34 \\
(0.25)\end{array}$ & $\begin{array}{c}0.34 \\
(0.25)\end{array}$ & $\begin{array}{c}0.34 \\
(0.25)\end{array}$ & $\begin{array}{c}0.34 \\
(0.25)\end{array}$ & $\begin{array}{c}0.34 \\
(0.25)\end{array}$ & $\begin{array}{c}0.34 \\
(0.25)\end{array}$ \\
\hline lcdd & $\begin{array}{l}-0.09 \\
(0.08)\end{array}$ & $\begin{array}{l}-0.09 \\
(0.08)\end{array}$ & $\begin{array}{l}-0.10 \\
(0.08)\end{array}$ & $\begin{array}{l}-0.10 \\
(0.08)\end{array}$ & $\begin{array}{l}-0.10 \\
(0.09)\end{array}$ & $\begin{array}{l}-0.10 \\
(0.09)\end{array}$ & $\begin{array}{l}-0.10 \\
(0.09)\end{array}$ & $\begin{array}{l}-0.10 \\
(0.09)\end{array}$ \\
\hline lpop & $\begin{array}{l}-1.76 \\
(0.50)\end{array}$ & $\begin{array}{l}-1.76 \\
(0.50)\end{array}$ & $\begin{array}{l}-1.59 \\
(0.49)\end{array}$ & $\begin{array}{l}-1.59 \\
(0.49)\end{array}$ & $\begin{array}{l}-1.63 \\
(0.50)\end{array}$ & $\begin{array}{l}-1.63 \\
(0.50)\end{array}$ & $\begin{array}{l}-1.63 \\
(0.50)\end{array}$ & $\begin{array}{l}-1.63 \\
(0.50)\end{array}$ \\
\hline hlcv & & & $\begin{array}{l}-0.002 \\
(0.00)\end{array}$ & $\begin{array}{l}-0.002 \\
(0.00)\end{array}$ & $\begin{array}{l}-0.002 \\
(0.00)\end{array}$ & $\begin{array}{l}-0.002 \\
(0.00)\end{array}$ & $\begin{array}{l}-0.002 \\
(0.00)\end{array}$ & $\begin{array}{l}-0.002 \\
(0.00)\end{array}$ \\
\hline slcv & & & $\begin{array}{c}-0.0004 \\
(0.00)\end{array}$ & $\begin{array}{c}-0.0004 \\
(0.00)\end{array}$ & $\begin{array}{c}-0.0004 \\
(0.00)\end{array}$ & $\begin{array}{c}-0.0004 \\
(0.00)\end{array}$ & $\begin{array}{c}-0.0004 \\
(0.00)\end{array}$ & $\begin{array}{c}-0.0004 \\
(0.00)\end{array}$ \\
\hline eres & & & $\begin{array}{c}0.07 \\
(0.05)\end{array}$ & $\begin{array}{c}0.07 \\
(0.05)\end{array}$ & $\begin{array}{c}0.07 \\
(0.05)\end{array}$ & $\begin{array}{c}0.07 \\
(0.05)\end{array}$ & $\begin{array}{c}0.07 \\
(0.05)\end{array}$ & $\begin{array}{c}0.07 \\
(0.05)\end{array}$ \\
\hline ees & & & $\begin{array}{l}-0.03 \\
(0.04)\end{array}$ & $\begin{array}{l}-0.03 \\
(0.04)\end{array}$ & $\begin{array}{l}-0.03 \\
(0.04)\end{array}$ & $\begin{array}{l}-0.03 \\
(0.04)\end{array}$ & $\begin{array}{l}-0.03 \\
(0.04)\end{array}$ & $\begin{array}{l}-0.03 \\
(0.04)\end{array}$ \\
\hline$c t i$ & & & $\begin{array}{l}-0.11 \\
(0.04)\end{array}$ & $\begin{array}{l}-0.11 \\
(0.04)\end{array}$ & $\begin{array}{l}-0.11 \\
(0.04)\end{array}$ & $\begin{array}{l}-0.11 \\
(0.04)\end{array}$ & $\begin{array}{l}-0.11 \\
(0.04)\end{array}$ & $\begin{array}{l}-0.11 \\
(0.04)\end{array}$ \\
\hline $\operatorname{spf}$ & & & $\begin{array}{c}0.02 \\
(0.05)\end{array}$ & $\begin{array}{c}0.02 \\
(0.05)\end{array}$ & $\begin{array}{c}0.02 \\
(0.05)\end{array}$ & $\begin{array}{c}0.02 \\
(0.05)\end{array}$ & $\begin{array}{c}0.02 \\
(0.05)\end{array}$ & $\begin{array}{c}0.02 \\
(0.05)\end{array}$ \\
\hline$g$-ideo & & & $\begin{array}{c}0.002 \\
(0.001)\end{array}$ & $\begin{array}{l}0.002 \\
(0.00)\end{array}$ & $\begin{array}{l}0.001 \\
(0.00)\end{array}$ & $\begin{array}{l}0.001 \\
(0.00)\end{array}$ & $\begin{array}{l}0.001 \\
(0.00)\end{array}$ & $\begin{array}{l}0.001 \\
(0.00)\end{array}$ \\
\hline c-ideo & & & $\begin{array}{l}-0.002 \\
(0.00)\end{array}$ & $\begin{array}{l}-0.002 \\
(0.00)\end{array}$ & $\begin{array}{l}-0.002 \\
(0.00)\end{array}$ & $\begin{array}{l}-0.002 \\
(0.00)\end{array}$ & $\begin{array}{l}-0.002 \\
(0.00)\end{array}$ & $\begin{array}{r}-0.002 \\
(0.00)\end{array}$ \\
\hline $\operatorname{lngp}$ & & & & & $\begin{array}{c}0.20 \\
(0.19)\end{array}$ & $\begin{array}{c}0.20 \\
(0.19)\end{array}$ & $\begin{array}{c}0.19 \\
(0.19)\end{array}$ & $\begin{array}{c}0.19 \\
(0.19)\end{array}$ \\
\hline$e$-imp & & & & & & & $\begin{array}{l}-0.02 \\
(0.08)\end{array}$ & $\begin{array}{l}-0.02 \\
(0.08)\end{array}$ \\
\hline Observations & 1170 & 1170 & 1170 & 1170 & 1170 & 1170 & 1170 & 1170 \\
\hline State fixed effects & Yes & Yes & Yes & Yes & Yes & Yes & Yes & Yes \\
\hline Year fixed effects & Yes & Yes & Yes & Yes & Yes & Yes & Yes & Yes \\
\hline Adj R-squared & 0.27 & 0.27 & 0.29 & 0.29 & 0.29 & 0.29 & 0.29 & 0.29 \\
\hline
\end{tabular}

Notes: The dependent variable is logged dispatchable renewable electricity generation per capita. Robust standard errors are clustered at the state level in parentheses. 
Table C7.1: Estimated Determinants of How RPS Requirements Relate to Intermittent Renewable Generation

\begin{tabular}{|c|c|c|c|c|c|c|c|c|}
\hline & (1) & (2) & (3) & (4) & (5) & (6) & (7) & (8) \\
\hline$a-r p s$ & $\begin{array}{c}0.84 \\
(0.51)\end{array}$ & & $\begin{array}{c}0.78 \\
(0.45)\end{array}$ & & $\begin{array}{c}0.79 \\
(0.45)\end{array}$ & & $\begin{array}{c}0.78 \\
(0.45)\end{array}$ & \\
\hline$r$-rps & $\begin{array}{c}-42.7 \\
(105.5)\end{array}$ & $\begin{array}{c}-48.6 \\
(107.5)\end{array}$ & $\begin{array}{c}-26.7 \\
(103.6)\end{array}$ & $\begin{array}{c}-30.4 \\
(104.5)\end{array}$ & $\begin{array}{l}-33.5 \\
(98.7)\end{array}$ & $\begin{array}{l}-37.2 \\
(99.6)\end{array}$ & $\begin{array}{l}-23.31 \\
(97.0)\end{array}$ & $\begin{array}{l}-26.94 \\
(98.1)\end{array}$ \\
\hline$r$-rps $\times i$-rep & $\begin{array}{l}-3.98 \\
(3.67)\end{array}$ & $\begin{array}{l}-2.63 \\
(4.05)\end{array}$ & $\begin{array}{l}-5.39 \\
(3.90)\end{array}$ & $\begin{array}{l}-4.63 \\
(4.11)\end{array}$ & $\begin{array}{l}-5.30 \\
(3.43)\end{array}$ & $\begin{array}{l}-4.54 \\
(3.66)\end{array}$ & $\begin{array}{l}-3.91 \\
(3.93)\end{array}$ & $\begin{array}{l}-3.15 \\
(3.92)\end{array}$ \\
\hline$r$-rps $\times d$-rep & $\begin{array}{c}8.81 \\
(2.70)\end{array}$ & $\begin{array}{c}7.87 \\
(2.86)\end{array}$ & $\begin{array}{c}8.18 \\
(2.59)\end{array}$ & $\begin{array}{c}7.74 \\
(2.63)\end{array}$ & $\begin{array}{c}7.86 \\
(2.24)\end{array}$ & $\begin{array}{c}7.42 \\
(2.31)\end{array}$ & $\begin{array}{c}7.33 \\
(2.43)\end{array}$ & $\begin{array}{c}6.89 \\
(2.41)\end{array}$ \\
\hline$r$-rps $\times w$-inter & $\begin{array}{l}-15.6 \\
(30.1)\end{array}$ & $\begin{array}{l}-11.2 \\
(30.5)\end{array}$ & $\begin{array}{l}-15.2 \\
(29.6)\end{array}$ & $\begin{array}{l}-12.8 \\
(29.6)\end{array}$ & $\begin{array}{l}-11.9 \\
(27.8)\end{array}$ & $\begin{array}{l}-9.48 \\
(27.9)\end{array}$ & $\begin{array}{l}-16.02 \\
(27.2)\end{array}$ & $\begin{array}{l}-13.7 \\
(27.2)\end{array}$ \\
\hline lhdd & $\begin{array}{l}-1.07 \\
(1.35)\end{array}$ & $\begin{array}{l}-1.06 \\
(1.36)\end{array}$ & $\begin{array}{l}-1.58 \\
(1.34)\end{array}$ & $\begin{array}{l}-1.50 \\
(1.32)\end{array}$ & $\begin{array}{l}-1.49 \\
(1.34)\end{array}$ & $\begin{array}{l}-1.41 \\
(1.33)\end{array}$ & $\begin{array}{l}-1.252 \\
(1.27)\end{array}$ & $\begin{array}{l}-1.17 \\
(1.27)\end{array}$ \\
\hline lcdd & $\begin{array}{c}1.17 \\
(0.71)\end{array}$ & $\begin{array}{c}1.18 \\
(0.70)\end{array}$ & $\begin{array}{c}0.87 \\
(0.65)\end{array}$ & $\begin{array}{c}0.88 \\
(0.65)\end{array}$ & $\begin{array}{c}0.96 \\
(0.65)\end{array}$ & $\begin{array}{c}0.97 \\
(0.64)\end{array}$ & $\begin{array}{l}0.944 \\
(0.67)\end{array}$ & $\begin{array}{c}0.95 \\
(0.67)\end{array}$ \\
\hline lpop & $\begin{array}{l}-1.52 \\
(6.34)\end{array}$ & $\begin{array}{l}-1.78 \\
(6.39)\end{array}$ & $\begin{array}{l}-0.76 \\
(6.50)\end{array}$ & $\begin{array}{l}-0.36 \\
(6.68)\end{array}$ & $\begin{array}{l}-1.63 \\
(6.41)\end{array}$ & $\begin{array}{l}-1.20 \\
(6.58)\end{array}$ & $\begin{array}{l}-1.41 \\
(5.95)\end{array}$ & $\begin{array}{l}-0.99 \\
(6.11)\end{array}$ \\
\hline hlcv & & & $\begin{array}{l}0.006 \\
(0.01)\end{array}$ & $\begin{array}{l}0.006 \\
(0.01)\end{array}$ & $\begin{array}{l}0.004 \\
(0.01)\end{array}$ & $\begin{array}{l}0.005 \\
(0.01)\end{array}$ & $\begin{array}{l}0.003 \\
(0.01)\end{array}$ & $\begin{array}{l}0.003 \\
(0.01)\end{array}$ \\
\hline slcv & & & $\begin{array}{l}0.008 \\
(0.01)\end{array}$ & $\begin{array}{l}0.009 \\
(0.01)\end{array}$ & $\begin{array}{l}0.008 \\
(0.01)\end{array}$ & $\begin{array}{l}0.009 \\
(0.01)\end{array}$ & $\begin{array}{l}0.008 \\
(0.01)\end{array}$ & $\begin{array}{c}0.01 \\
(0.01)\end{array}$ \\
\hline eres & & & $\begin{array}{l}-0.40 \\
(0.50)\end{array}$ & $\begin{array}{l}-0.32 \\
(0.50)\end{array}$ & $\begin{array}{l}-0.42 \\
(0.48)\end{array}$ & $\begin{array}{l}-0.34 \\
(0.49)\end{array}$ & $\begin{array}{l}-0.28 \\
(0.49)\end{array}$ & $\begin{array}{l}-0.20 \\
(0.50)\end{array}$ \\
\hline ees & & & $\begin{array}{l}-0.16 \\
(0.57)\end{array}$ & $\begin{array}{l}-0.053 \\
(0.59)\end{array}$ & $\begin{array}{l}-0.14 \\
(0.56)\end{array}$ & $\begin{array}{l}-0.037 \\
(0.58)\end{array}$ & $\begin{array}{c}-0.0003 \\
(0.54)\end{array}$ & $\begin{array}{l}0.103 \\
(0.56)\end{array}$ \\
\hline$c t i$ & & & $\begin{array}{l}-0.25 \\
(0.65)\end{array}$ & $\begin{array}{l}-0.22 \\
(0.65)\end{array}$ & $\begin{array}{l}-0.23 \\
(0.64)\end{array}$ & $\begin{array}{l}-0.20 \\
(0.65)\end{array}$ & $\begin{array}{c}-0.348 \\
(0.58)\end{array}$ & $\begin{array}{l}-0.323 \\
(0.59)\end{array}$ \\
\hline spf & & & $\begin{array}{l}-0.06 \\
(0.45)\end{array}$ & $\begin{array}{c}0.02 \\
(0.44)\end{array}$ & $\begin{array}{l}-0.002 \\
(0.43)\end{array}$ & $\begin{array}{c}0.07 \\
(0.43)\end{array}$ & $\begin{array}{c}0.05 \\
(0.44)\end{array}$ & $\begin{array}{c}0.13 \\
(0.44)\end{array}$ \\
\hline g-ideo & & & $\begin{array}{c}0.02 \\
(0.01)\end{array}$ & $\begin{array}{c}0.03 \\
(0.01)\end{array}$ & $\begin{array}{c}0.02 \\
(0.01)\end{array}$ & $\begin{array}{c}0.02 \\
(0.01)\end{array}$ & $\begin{array}{c}0.02 \\
(0.01)\end{array}$ & $\begin{array}{c}0.02 \\
(0.01)\end{array}$ \\
\hline c-ideo & & & $\begin{array}{l}-0.07 \\
(0.02)\end{array}$ & $\begin{array}{l}-0.06 \\
(0.02)\end{array}$ & $\begin{array}{l}-0.06 \\
(0.02)\end{array}$ & $\begin{array}{l}-0.06 \\
(0.02)\end{array}$ & $\begin{array}{l}-0.05 \\
(0.02)\end{array}$ & $\begin{array}{l}-0.05 \\
(0.02)\end{array}$ \\
\hline $\operatorname{lngp}$ & & & & & $\begin{array}{c}3.39 \\
(1.58)\end{array}$ & $\begin{array}{c}3.36 \\
(1.61)\end{array}$ & $\begin{array}{c}3.93 \\
(1.50)\end{array}$ & $\begin{array}{c}3.89 \\
(1.55)\end{array}$ \\
\hline$e$-imp & & & & & & & $\begin{array}{c}2.27 \\
(0.68) \\
\end{array}$ & $\begin{array}{c}2.27 \\
(0.66) \\
\end{array}$ \\
\hline Observations & 1196 & 1196 & 1196 & 1196 & 1196 & 1196 & 1196 & 1196 \\
\hline State fixed effects & Yes & Yes & Yes & Yes & Yes & Yes & Yes & Yes \\
\hline Year fixed effects & Yes & Yes & Yes & Yes & Yes & Yes & Yes & Yes \\
\hline Adj R-squared & 0.63 & 0.63 & 0.65 & 0.65 & 0.66 & 0.66 & 0.68 & 0.68 \\
\hline
\end{tabular}

Notes: The dependent variable is logged intermittent renewable electricity generation per capita. Robust standard errors are clustered at the state level in parentheses. 
Table C7.2: Estimated Determinants of How RPS Requirements Relate to Intermittent Renewable Generation

\begin{tabular}{|c|c|c|c|c|c|c|c|c|}
\hline & (1) & (2) & (3) & (4) & (5) & (6) & (7) & (8) \\
\hline$a-r p s$ & $\begin{array}{c}0.57 \\
(0.67)\end{array}$ & & $\begin{array}{c}0.38 \\
(0.64)\end{array}$ & & $\begin{array}{c}0.47 \\
(0.64)\end{array}$ & & $\begin{array}{c}0.39 \\
(0.66)\end{array}$ & \\
\hline$r$-rps & $\begin{array}{c}-48.8 \\
(98.4)\end{array}$ & $\begin{array}{c}-48.8 \\
(98.4)\end{array}$ & $\begin{array}{l}-34.4 \\
(97.3)\end{array}$ & $\begin{array}{l}-34.4 \\
(97.3)\end{array}$ & $\begin{array}{l}-38.6 \\
(94.2)\end{array}$ & $\begin{array}{l}-38.6 \\
(94.2)\end{array}$ & $\begin{array}{l}-32.5 \\
(92.1)\end{array}$ & $\begin{array}{c}-32.5 \\
(92.1)\end{array}$ \\
\hline$r$-rps $\times i$-rep & $\begin{array}{c}-2.86 \\
(4.17)\end{array}$ & $\begin{array}{c}-2.86 \\
(4.17)\end{array}$ & $\begin{array}{l}-4.34 \\
(4.17)\end{array}$ & $\begin{array}{c}-4.34 \\
(4.17)\end{array}$ & $\begin{array}{l}-4.40 \\
(3.74)\end{array}$ & $\begin{array}{l}-4.40 \\
(3.74)\end{array}$ & $\begin{array}{l}-2.90 \\
(4.26)\end{array}$ & $\begin{array}{l}-2.90 \\
(4.26)\end{array}$ \\
\hline$r$-rps $\times d$-rep & $\begin{array}{c}7.35 \\
(3.11)\end{array}$ & $\begin{array}{c}7.35 \\
(3.11)\end{array}$ & $\begin{array}{c}6.98 \\
(2.64)\end{array}$ & $\begin{array}{c}6.98 \\
(2.64)\end{array}$ & $\begin{array}{c}6.74 \\
(2.37)\end{array}$ & $\begin{array}{c}6.74 \\
(2.37)\end{array}$ & $\begin{array}{c}6.49 \\
(2.53)\end{array}$ & $\begin{array}{c}6.49 \\
(2.53)\end{array}$ \\
\hline$r$-rps $\times w$-inter & $\begin{array}{c}-9.71 \\
(28.2)\end{array}$ & $\begin{array}{l}-9.71 \\
(28.2)\end{array}$ & $\begin{array}{l}-9.67 \\
(27.4)\end{array}$ & $\begin{array}{l}-9.67 \\
(27.4)\end{array}$ & $\begin{array}{l}-7.28 \\
(26.2)\end{array}$ & $\begin{array}{l}-7.28 \\
(26.2)\end{array}$ & $\begin{array}{l}-11.5 \\
(25.3)\end{array}$ & $\begin{array}{l}-11.5 \\
(25.3)\end{array}$ \\
\hline$A C P$ & $\begin{array}{c}-0.19 \\
(0.61)\end{array}$ & $\begin{array}{c}-0.19 \\
(0.61)\end{array}$ & $\begin{array}{c}-0.13 \\
(0.60)\end{array}$ & $\begin{array}{c}-0.13 \\
(0.60)\end{array}$ & $\begin{array}{l}-0.18 \\
(0.59)\end{array}$ & $\begin{array}{l}-0.18 \\
(0.59)\end{array}$ & $\begin{array}{c}0.10 \\
(0.63)\end{array}$ & $\begin{array}{c}0.10 \\
(0.63)\end{array}$ \\
\hline Multiplier & $\begin{array}{c}0.99 \\
(0.60)\end{array}$ & $\begin{array}{c}0.99 \\
(0.60)\end{array}$ & $\begin{array}{c}1.02 \\
(0.54)\end{array}$ & $\begin{array}{c}1.02 \\
(0.54)\end{array}$ & $\begin{array}{c}0.91 \\
(0.53)\end{array}$ & $\begin{array}{c}0.91 \\
(0.53)\end{array}$ & $\begin{array}{c}0.82 \\
(0.56)\end{array}$ & $\begin{array}{c}0.82 \\
(0.56)\end{array}$ \\
\hline Carveout & $\begin{array}{c}-0.31 \\
(0.57)\end{array}$ & $\begin{array}{c}-0.31 \\
(0.57)\end{array}$ & $\begin{array}{l}-0.17 \\
(0.54)\end{array}$ & $\begin{array}{c}-0.17 \\
(0.54)\end{array}$ & $\begin{array}{l}-0.16 \\
(0.52)\end{array}$ & $\begin{array}{l}-0.16 \\
(0.52)\end{array}$ & $\begin{array}{c}-0.20 \\
(0.53)\end{array}$ & $\begin{array}{l}-0.20 \\
(0.53)\end{array}$ \\
\hline Trading & $\begin{array}{c}0.00 \\
(0.00)\end{array}$ & $\begin{array}{c}0.57 \\
(0.67)\end{array}$ & $\begin{array}{c}0.00 \\
(0.00)\end{array}$ & $\begin{array}{c}0.38 \\
(0.64)\end{array}$ & $\begin{array}{c}0.00 \\
(0.00)\end{array}$ & $\begin{array}{c}0.47 \\
(0.64)\end{array}$ & $\begin{array}{c}0.00 \\
(0.00)\end{array}$ & $\begin{array}{c}0.39 \\
(0.66)\end{array}$ \\
\hline lhdd & $\begin{array}{c}-1.22 \\
(1.28)\end{array}$ & $\begin{array}{c}-1.22 \\
(1.28)\end{array}$ & $\begin{array}{l}-1.70 \\
(1.29)\end{array}$ & $\begin{array}{c}-1.70 \\
(1.29)\end{array}$ & $\begin{array}{l}-1.59 \\
(1.29)\end{array}$ & $\begin{array}{l}-1.59 \\
(1.29)\end{array}$ & $\begin{array}{c}-1.40 \\
(1.22)\end{array}$ & $\begin{array}{l}-1.40 \\
(1.22)\end{array}$ \\
\hline lcdd & $\begin{array}{c}1.23 \\
(0.71)\end{array}$ & $\begin{array}{c}1.23 \\
(0.71)\end{array}$ & $\begin{array}{c}0.93 \\
(0.64)\end{array}$ & $\begin{array}{c}0.93 \\
(0.64)\end{array}$ & $\begin{array}{c}1.01 \\
(0.64)\end{array}$ & $\begin{array}{c}1.01 \\
(0.64)\end{array}$ & $\begin{array}{c}0.97 \\
(0.66)\end{array}$ & $\begin{array}{c}0.97 \\
(0.66)\end{array}$ \\
\hline lpop & $\begin{array}{c}-4.51 \\
(6.57)\end{array}$ & $\begin{array}{l}-4.51 \\
(6.57)\end{array}$ & $\begin{array}{l}-3.79 \\
(6.46)\end{array}$ & $\begin{array}{l}-3.79 \\
(6.46)\end{array}$ & $\begin{array}{l}-4.32 \\
(6.41)\end{array}$ & $\begin{array}{l}-4.32 \\
(6.41)\end{array}$ & $\begin{array}{l}-3.59 \\
(5.95)\end{array}$ & $\begin{array}{l}-3.59 \\
(5.95)\end{array}$ \\
\hline hlcv & & & $\begin{array}{c}0.05 \\
(0.01)\end{array}$ & $\begin{array}{c}0.005 \\
(0.01)\end{array}$ & $\begin{array}{l}0.004 \\
(0.01)\end{array}$ & $\begin{array}{l}0.004 \\
(0.01)\end{array}$ & $\begin{array}{c}0.002 \\
(0.01)\end{array}$ & $\begin{array}{l}0.002 \\
(0.01)\end{array}$ \\
\hline slcv & & & $\begin{array}{c}0.01 \\
(0.00)\end{array}$ & $\begin{array}{c}0.01 \\
(0.00)\end{array}$ & $\begin{array}{c}0.01 \\
(0.00)\end{array}$ & $\begin{array}{c}0.01 \\
(0.00)\end{array}$ & $\begin{array}{c}0.01 \\
(0.00)\end{array}$ & $\begin{array}{c}0.01 \\
(0.00)\end{array}$ \\
\hline eres & & & $\begin{array}{l}-0.45 \\
(0.49)\end{array}$ & $\begin{array}{l}-0.45 \\
(0.49)\end{array}$ & $\begin{array}{l}-0.46 \\
(0.48)\end{array}$ & $\begin{array}{l}-0.46 \\
(0.48)\end{array}$ & $\begin{array}{l}-0.35 \\
(0.48)\end{array}$ & $\begin{array}{l}-0.35 \\
(0.48)\end{array}$ \\
\hline ees & & & $\begin{array}{l}-0.21 \\
(0.57)\end{array}$ & $\begin{array}{c}-0.21 \\
(0.57)\end{array}$ & $\begin{array}{l}-0.19 \\
(0.57)\end{array}$ & $\begin{array}{l}-0.19 \\
(0.57)\end{array}$ & $\begin{array}{c}-0.04 \\
(0.55)\end{array}$ & $\begin{array}{c}-0.04 \\
(0.55)\end{array}$ \\
\hline$c t i$ & & & $\begin{array}{c}-0.32 \\
(0.65)\end{array}$ & $\begin{array}{c}-0.32 \\
(0.65)\end{array}$ & $\begin{array}{l}-0.29 \\
(0.65)\end{array}$ & $\begin{array}{l}-0.29 \\
(0.65)\end{array}$ & $\begin{array}{c}-0.41 \\
(0.60)\end{array}$ & $\begin{array}{c}-0.41 \\
(0.60)\end{array}$ \\
\hline $\operatorname{spf}$ & & & $\begin{array}{c}0.12 \\
(0.45)\end{array}$ & $\begin{array}{c}0.12 \\
(0.45)\end{array}$ & $\begin{array}{c}0.15 \\
(0.43)\end{array}$ & $\begin{array}{c}0.15 \\
(0.43)\end{array}$ & $\begin{array}{c}0.18 \\
(0.45)\end{array}$ & $\begin{array}{c}0.18 \\
(0.45)\end{array}$ \\
\hline g-ideo & & & $\begin{array}{c}0.02 \\
(0.01)\end{array}$ & $\begin{array}{c}0.02 \\
(0.01)\end{array}$ & $\begin{array}{c}0.02 \\
(0.01)\end{array}$ & $\begin{array}{c}0.02 \\
(0.01)\end{array}$ & $\begin{array}{c}0.02 \\
(0.01)\end{array}$ & $\begin{array}{c}0.02 \\
(0.01)\end{array}$ \\
\hline c-ideo & & & $\begin{array}{l}-0.06 \\
(0.02)\end{array}$ & $\begin{array}{c}-0.06 \\
(0.02)\end{array}$ & $\begin{array}{l}-0.06 \\
(0.02)\end{array}$ & $\begin{array}{l}-0.06 \\
(0.02)\end{array}$ & $\begin{array}{c}-0.05 \\
(0.02)\end{array}$ & $\begin{array}{l}-0.05 \\
(0.02)\end{array}$ \\
\hline $\operatorname{lngp}$ & & & & & $\begin{array}{c}3.10 \\
(1.61)\end{array}$ & $\begin{array}{c}3.10 \\
(1.61)\end{array}$ & $\begin{array}{c}3.61 \\
(1.52)\end{array}$ & $\begin{array}{c}3.61 \\
(1.52)\end{array}$ \\
\hline$e$-imp & & & & & & & $\begin{array}{c}2.24 \\
(0.71) \\
\end{array}$ & $\begin{array}{c}2.24 \\
(0.71)\end{array}$ \\
\hline Observations & 1196 & 1196 & 1196 & 1196 & 1196 & 1196 & 1196 & 1196 \\
\hline State fixed effects & Yes & Yes & Yes & Yes & Yes & Yes & Yes & Yes \\
\hline Year fixed effects & Yes & Yes & Yes & Yes & Yes & Yes & Yes & Yes \\
\hline Adj R-squared & 0.64 & 0.64 & 0.66 & 0.66 & 0.66 & 0.66 & 0.68 & 0.68 \\
\hline
\end{tabular}

Notes: The dependent variable is logged intermittent renewable electricity generation per capita. Robust standard errors are clustered at the state level in parentheses. 
Figure C.1: Effects of RPS Adoption on Each Outcome with Balanced Sample in Event Time

(b)

(a)

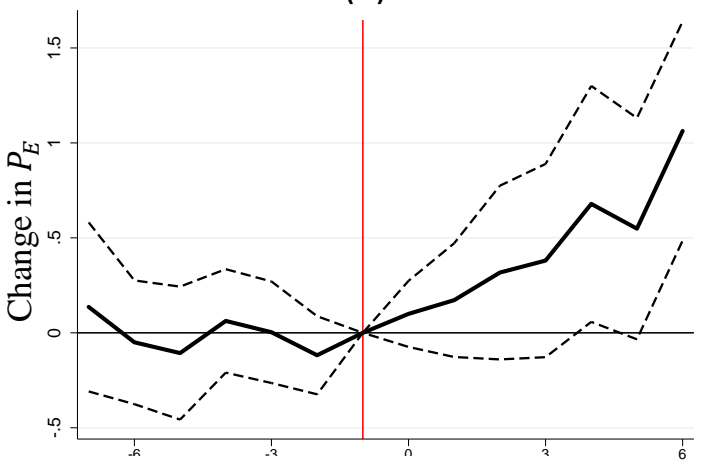

Years Before and After RPS Adoption

(c)

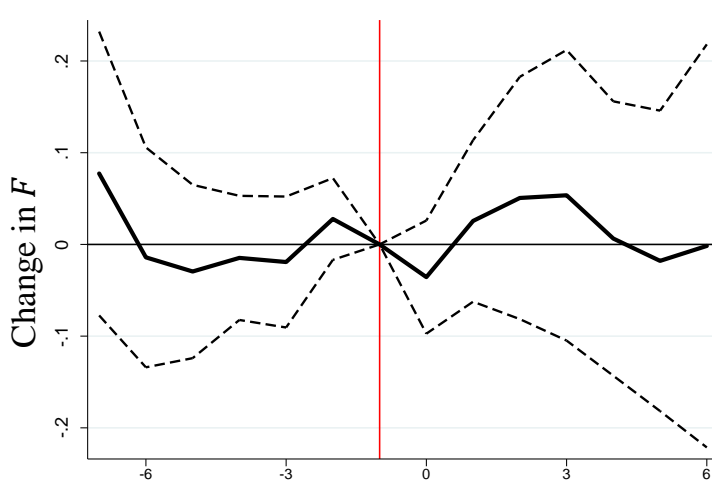

Years Before and After RPS Adoption

(e)

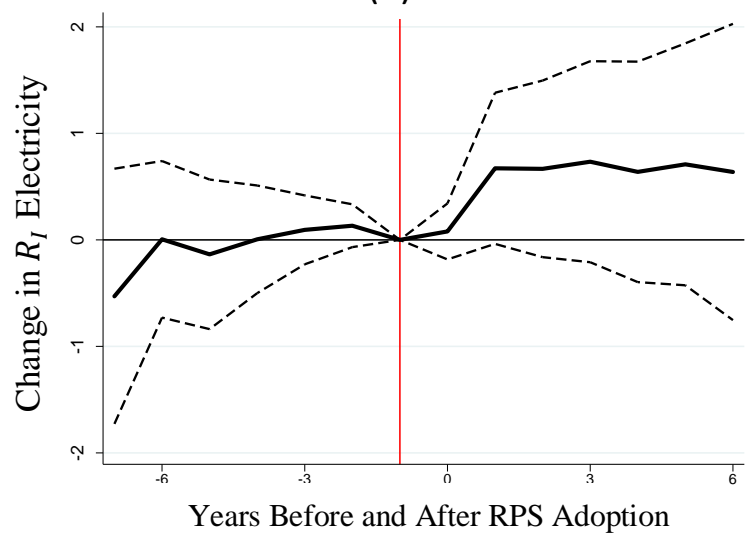

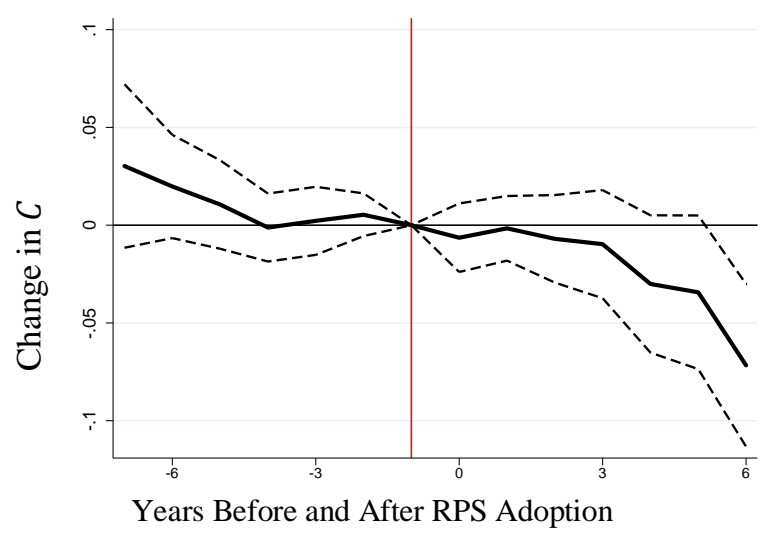

(d)

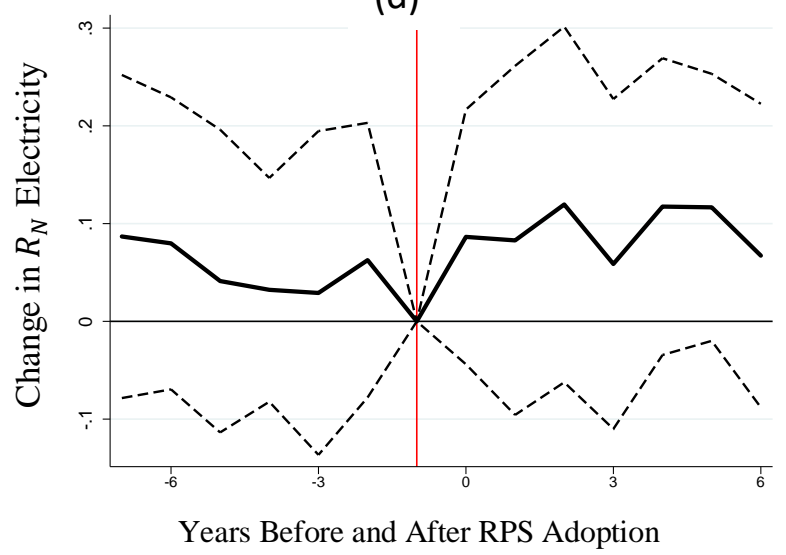

Notes: This figure illustrates the event-study regression results. The vertical axis shows change in electricity price in (a), change in logged total carbon dioxide emissions per capita in (b), change in logged fossil fuel electricity per capita in (c), change in logged dispatchable renewable electricity per capita in (d), and change in the inverse hyperbolic sine transformation of intermittent renewable electricity generation per capita in (e). The horizontal axis shows the number of years relative to the policy adoption. The solid line represents point estimates and the dashed line indicates 95\% confidence intervals. The standard errors are clustered at the state level. Controls include state and year fixed effects. 


\section{Figure C2: Effects of RPS Adoption on Each Outcome Over Time - Callaway and Sant'Anna (2020) Estimator}

(a)

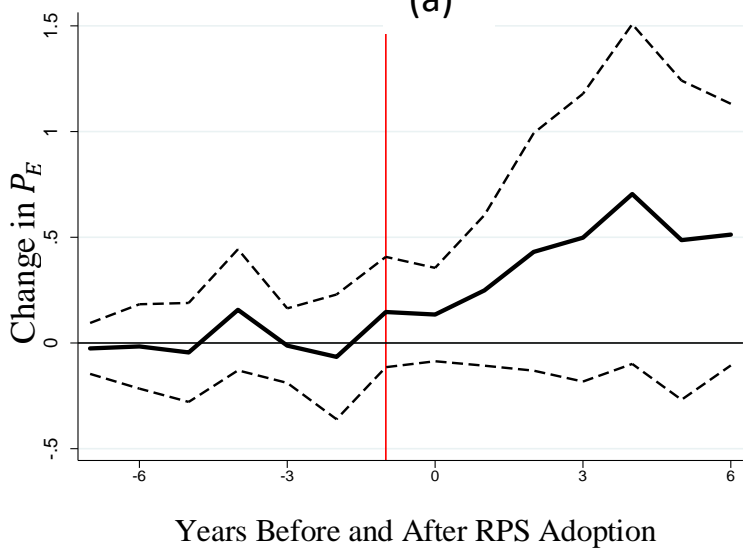

(c)

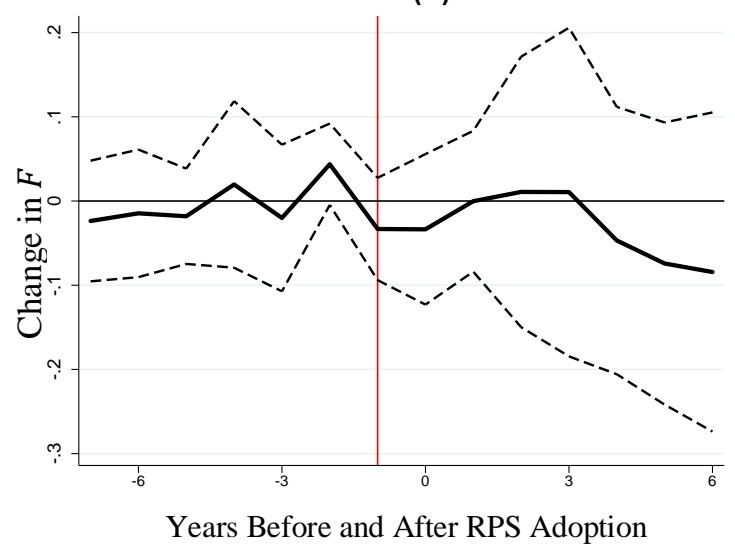

(e)

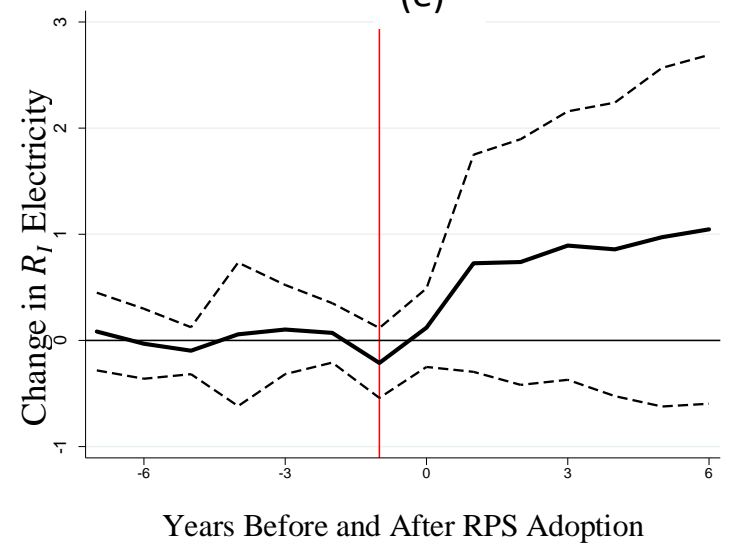

(b)

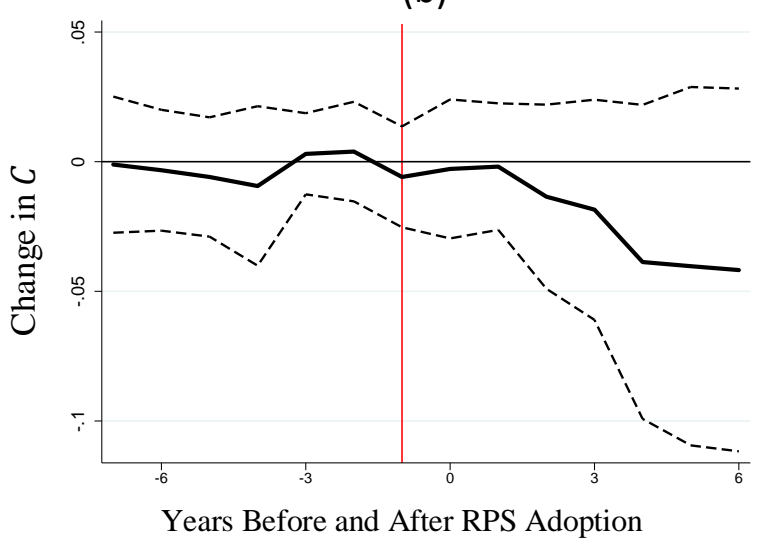

(d)

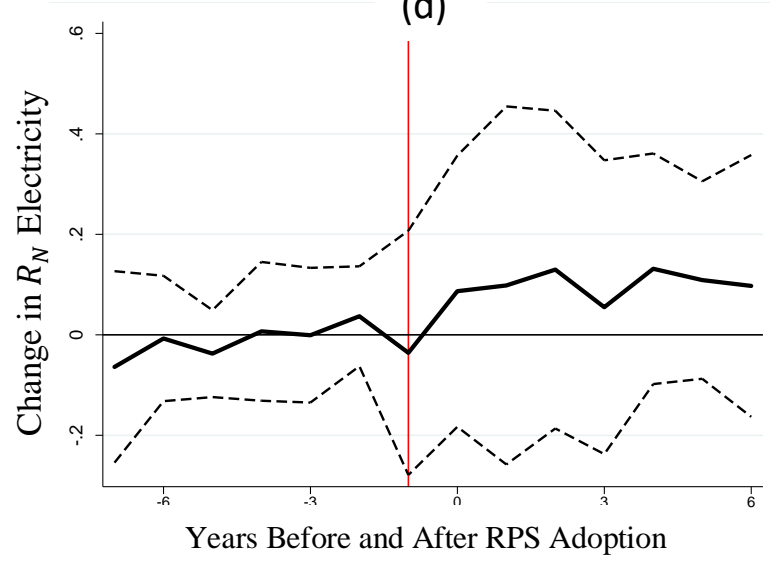

Notes: This figure illustrates the event-study regression result following Callaway and SantAnna (2020). The vertical axis shows change in electricity price in (a), change in logged total carbon dioxide emissions per capita in (b), change in logged fossil fuel electricity per capita in (c), change in logged dispatchable renewable electricity per capita in (d), and change in the inverse hyperbolic sine transformation of intermittent renewable electricity generation per capita in (e). The horizontal axis shows the number of years relative to the policy adoption. The solid line represents point estimates and the dashed line indicates $95 \%$ confidence intervals. 